\title{
4 Huts, Houses and Migrants: the Iron Age (c. 1000/900-600/550 BC)
}

\section{I THE B E I N N I G S OF THE IRON AGE}

By about the 10th century BC the South-Italian landscapes looked quite different from what they had been in the Late Bronze Age (LBA). This observation holds especially good for the coastal strip of southern Apulia, Basilicata and northern Calabria where most of the major LBA settlements had been located. But first of all, it should be observed that the continuity of occupation between Bronze Age and Iron Age was strong. Most of the LBA sites - often with Early Bronze Age or Middle Bronze Age origins - continued to be inhabited during the Final Bronze Age and the early Iron Age. Important LBA sites such as Timmari, Scoglio del Tonno (Taranto) and Rocavecchia were also settlements of considerable importance during the Iron Age. LBA sites of probably secondary importance had a comparable settlement history and often survived into the Iron Age. ${ }^{1}$

Of course, settlements were given up from time to time. This happened for a variety of reasons. But when this was done, it happened mainly in middle to later 8 th or early 7 th century BC. ${ }^{2}$ This means that during the first two centuries of the Iron Age human occupation took place in the same environmental niches as in the preceding Bronze Age phases. Settlements were mostly on the coast and on the gently sloping hills rising above river valleys, often in close proximity of the coast. As we shall see below, a major change in settlement patterns took place in various parts of southeast Italy the course of the 8th century BC.

One of the major characteristics of the Iron Age settlements of southeast Italy was that they were highly dispersed. This observation holds especially good for the earlier phase of this period (10th-8th century BC). When a settlement had been continuously occupied since the Late Bronze Age, its Iron Age inhabitants often lived both within and outside the LBA earthworks (aggeres) and were doubtlessly acquainted with the large three to five hundred year old tumuli or dolmens on the fringes of the former LBA territory. They lived in a landscape that - for them - contained impressive monuments produced by another world. None of the large tumulus burials or dolmens is reported to display traces of Iron Age activities. Therefore, the role of these LBA monuments in the Iron Age may have been different from that of the Mycenaean tholos graves which continued to be important points of reference for people living in Geometric Greece. However, since most of these Italian Bronze Age tumuli and dolmens were dismantled many years ago, some caution is needed here, especially since the continuity between Bronze Age and Iron Age is quite remarkable in southeast Italy and these monuments are highly conspicuous elements in the landscape.

1 For instance, the sites of Santa Maria d'Anglona (Basilicata), Porto Perone (Taranto area) or Santa Maria di Ripalta (Ofanto district).

2 From this time onward the traces of human occupation are faint or absent at, for instance, the sites of Torre
Castelluccia on the Gulf of Taranto and Toppo Daguzzo in northeast Basilicata. The same holds good for the important LBA site of Coppa Nevigata on the Gulf of Manfredonia (north-Apulia) which seems to have lost much of its importance during the early Iron Age. 

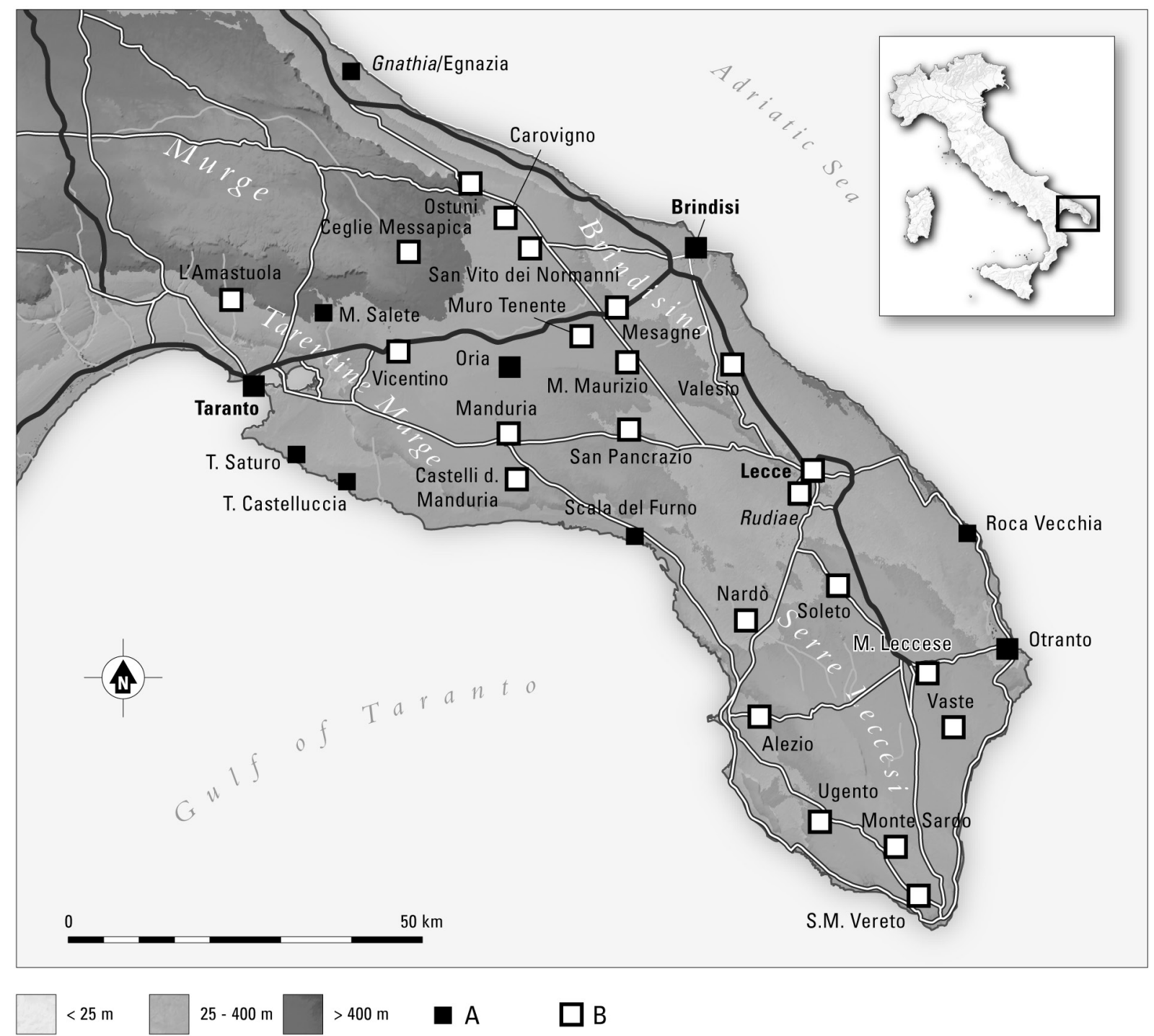

Fig. 4.1. Settlements in Salento around 700 BC. A settlements with Bronze Age origins; B settlements founded in the 8th century BC.

The present evidence suggests that southeast Italy was fairly thinly populated in the early stages of the Iron Age. The settlements were not only highly dispersed, they probably consisted of a relatively small number of households. The population figures for the 10th and 9th centuries BC were almost certainly considerably lower than those for the flourishing days of the Late Bronze Age. The various clusters of the mostly small settlements were strewn over the landscape. They occurred in fertile inland areas (e.g. the important site of Timmari), but as we have seen, they were often concentrated in coastal areas. This is remarkable, especially since in a part of the research area (notably in Apulia) the richest soils were certainly not on the coast. The continuing preference for a coastal location, therefore, seems to suggest that agriculture was certainly not the only, and perhaps in some cases not the most important economic activity of the societies of the early Iron-Age.

From about the middle of the 9th century the signs of human presence in the landscape become more numerous and more intense. Gradual landscape infill can be observed in the fertile zones with gently sloping hills in southern Basilicata. Here the Bronze Age site of Santa Maria d'Anglona spread out over 
dozens of hectares between the rivers Agri and Sinni, ${ }^{3}$ whilst the probably relatively modest Bronze Age site of San Teodoro spread over a plateau of 180 hectares between the rivers Basento and Cavone and evolved into the highly dispersed Iron Age site of L'Incoronata/San Teodoro. ${ }^{4}$ A similar gradual landscape infill can be surmised in the equally fertile plains of northern Apulia. Here the chain of hills south of the river Ofanto for which only a few sites have been reported for the Late Bronze Age, ${ }^{5}$ begins to show signs of more intense occupation foreshadowing the habitation patterns of the 7th and 6th centuries. By the end of the Iron Age this c. $30 \mathrm{~km}$ long range of hills displayed almost continuous, highly dispersed traces of habitation. These reached greater densities in the areas currently indicated as sites (Barletta, Canne, Canosa and Lavello). The 9th- to 8th-century necropoleis of Sala Consilina situated in the mountainous transition zone between southeast Italy and southern Campania, ${ }^{6}$ and the cemeteries of L'Incoronata in the coastal strip of Basilicata also demonstrate this general trend. ${ }^{7}$ They illustrate the presence of increasingly cohesive and increasingly populous groups in the landscapes of southeast Italy.

It is uncertain whether this increased visibility of human presence in the late 9th and early 8th centuries $\mathrm{BC}$ was the result of demographic growth, a change from semi-nomadism to a more sedentary, predominantly agrarian lifestyle, a combination of both, or still other factors. The fact is that the early 8th century BC also shows a marked regionalization in southeast Italy. In this period various 'cultural groups' came into being that are each characteristic of a particular geographic district with mostly clearly defined natural boundaries. ${ }^{8}$ These districts and the indigenous groups that reportedly populated them, have been discussed in chapter 3: the Opikoi, Oinotrioi and Chaones of Basilicata and southern Campania and the Daunioi, Peuketioi and Messapioi of Apulia (the six Greek labels mentioned in the ancient sources) and the eight cultural entities which have been distinguished by modern scholars. Each of these eight groups started to display a combination of features that is utterly characteristic of that particular group and that particular district only (see section 4.6 of this chapter). These may regard, for instance, the 'use' of the landscape, settlement forms, types of dwellings, burial customs, religious activities, the composition of the livestock, ceramic style, types of bronzes, etc. These regional characteristics will be discussed in the following sections 4.2-4.6.

During the 7 th and 6th centuries the characteristics of the various regional cultural groups became more and more pronounced. Although from the later 6th century onward cultural influences from Greeks living in southern Italy had a strongly homogenizing effect on the indigenous cultural groups of the various districts, it was not before the 3rd century BC that these regional peculiarities within southeast Italy began to vanish definitively. This process of 'cultural unification' was more or less completed in the 1st century BC when peninsular Italy was unified under Roman rule, when migrations had dramatically changed the composition of the population and when interregional contacts within Italy and relations with areas outside Italy had become very intense indeed. ${ }^{9}$

\subsection{S E T T L E M E T A N D L A N D S C A P E}

The causes for the gradual human infill of the landscape from the middle of the 9th century onward must remain uncertain. But it was in the 3rd and 4th quarters of the 8 th century that this phenomenon gained momentum and resulted in a series of drastic changes in the landscapes of southeast Italy. The

\footnotetext{
Whitehouse / Whitehouse 1969, D’Ambrosio 1992, 7 Chiartano 1977, 1994, 1996. Giardino / De Siena 1999.

4 Pelosi 1991, Giardino/De Siena 1999.

5 The urnfield at Canosa (Lo Porto 1992a) and the habitation site of Madonna del Petto (Muntoni 1998).

8 The definition of the term 'cultural group' as used here has been given in chapter 3 .

For the (problematical) topic of the unification of Italy,
} Kilian 1964 and 1970. 


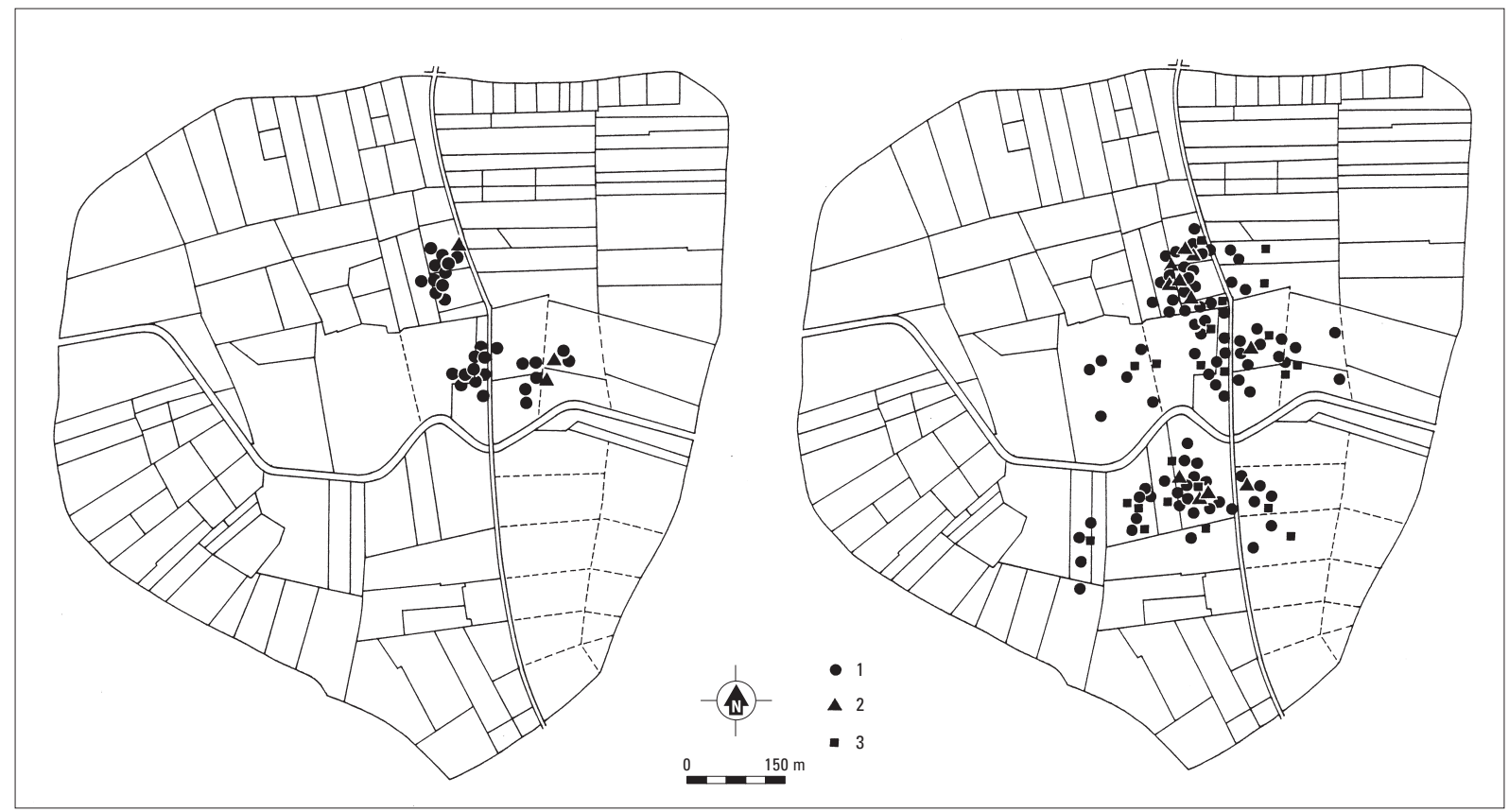

Fig. 4.2. Valesio (Salento district, south-Apulia), the earliest phases (urban survey). Distribution of 8th-century artifacts (left) and distribution of 7th-century artifacts (right) within the 4th-century walled town (with modern agricultural plots); 1 locally made matt-painted wares; 2 imported Greek pottery; 3 burnished impasto wares.

best evidence comes from the Salento peninsula. Here a series of settlements has been quite thoroughly investigated, ${ }^{10}$ while high intensity field surveys have been carried out in both the Brindisi area and the southern Murge hills in the northern part of the peninsula. These were of both urban and rural type, ${ }^{11}$ and supply important information for the construction of an image of the dynamics in the Iron Age settlement patterns. ${ }^{12}$ Therefore, the changes in settlement patterns that affected the Salento peninsula in the Iron Age will be discussed in some detail.

First it should be stressed that most settlements of the later phases of the Bronze Age continued to be inhabited in Salento during the Iron Age. But in this period the focus of human activity rapidly shifted. We have seen that in both the Late and the Final Bronze Age the majority of habitation centres was on the coast. For the settlements that originated in the 8th century BC, however, a new type of location was preferred: the new settlements of Iron Age Salento were definitely inland. The distances between the newly founded habitation centres and the settlements with Bronze Age roots were mostly between c. 10 and $25 \mathrm{~km}$. The new settlements arose almost invariably in areas with fertile, well-watered soils that were very suitable for the agriculturalist's activities by Iron Age standards. This means that entirely new areas were reclaimed for human occupation.

The number of new settlements in Salento, moreover, was surprisingly large. Between 760 and $720 \mathrm{BC}$ some 15 to 20 new settlements were born here. ${ }^{13}$ This quantity is larger than the number of

10 For instance, D'Andria 1999

11 With the term 'rural field survey' the now classic allperiod and complete-coverage field surveys are indicated (see Keller / Rupp 1983). The term 'urban survey' means that ancient, now abandoned settlements have been subjected to high intensity field surveys (cf. Bintliff and Snodgrass 1988). In the past decade both types of survey have been integrated resulting in a sophisticated system for the recovery of surface finds.

12 Yntema 1993a (Oria); Burgers 1998 (Muro Tenente, San Pancrazio, Muro Maurizio, Masseria Mea), Burgers et al. 1998 (Ostuni), Burgers / Recchia 2009, Crielaard 2011 (L'Amastuolo).

13 D’Andria 1991, 405; Burgers 1998, 186-191. 
coastal settlements of the Iron Age that had their origins in the Bronze Age. In a relatively short time (c. 50 years) the number of settlements more than doubled in Iron Age Salento (fig. 4.1). The new settlements represented in this count, moreover, are those rather conspicuous sites that were obviously successful and survived into the 6th or later centuries. Intensive field surveys, however, have revealed the presence of at least four very small 8th-century sites that were short-lived: they were occupied for no more than 30 to 40 years. ${ }^{14}$ If this data set obtained in survey areas with an extension of some 100 $\mathrm{km}^{2}$, is extrapolated to a regional scale, many more of these short-lived 8th-century settlements may be postulated. Hence it follows that the 8th century BC is likely to have been a highly dynamic period in which crucial changes took place in the settlement patterns of Salento. The present evidence suggests that all of a sudden people started to colonize formerly uninhabited inland areas of the Salento peninsula on a surprisingly large scale.

These dramatic changes in the settlement patterns that affected the Salento peninsula from about 760/740 BC, ask for explanations. These concern, for instance, the provenance and the size of the groups of colonists, their motives for creating new living areas and for selecting entirely new inland locations that differed from the traditional, basically coastal settlement systems. The last question can be answered by location analysis. It has already been said that the new settlements came into being on or near fertile calcareous, well-watered soils. These are invariably rich in springs or have water veins close to the surface that can be reached by constructing two to four m. deep wells. These data suggest that the 8th-century colonists were basically agriculturalists looking for farmland. The new locations they selected were spots where Iron Age farmers with Iron Age technologies could survive and thrive.

The origins of the people living in the new settlements can only be established somewhat hypothetically and along very general lines. The only way to tackle this problem is by analyzing the material remains of the new settlements. It appears that these did not differ from those found in contemporary settlements with Bronze Age roots. The layout of the new settlements, the dwellings and portable objects found in them all have exact parallels in the settlements with a much longer pedigree in this same district. Hence it follows that the groups that colonized inland Salento, were no newcomers from far-away areas. They consisted of people who had their origins in the tribal groups of the same peninsula. The families that populated the new settlements had split off from groups that lived in, or were closely connected with the Salento settlements with Bronze Age origins.

There are, moreover, data indicating the size of the groups of colonists that left their homes in order to occupy new areas. Intensive auguring in one of the small and short-lived settlements found during intensive field surveys around the isthmus site of Oria, revealed that it consisted of three to five huts. ${ }^{15}$ This suggests that the population living in this particular cluster of huts probably ranged between approximately 15 and 30 persons. ${ }^{16}$ Comparable data come from the urban survey of the site of Valesio (14 km south of Brindisi). Disastrous deep-ploughing activities immediately preceding the urban survey demonstrated that this settlement consisted of three nuclei of three to five huts each in its earliest phase (c. 750/740-710/700) (fig. 4.2, left). Since these huts were only partly contemporary, the population of Valesio in that very early phase of its existence may be estimated between minimally 30 and maximally 60 persons. ${ }^{17}$ The group that split off in order to found a new community, therefore, consisted of a few dozens of people (women and children included).

It was certainly not easy to leave one's settlement and start a new life in the midst of the Salento forests in the 8th century BC. This action required the arduous and time-consuming task of felling trees and clearing a substantial patch of forest in order to create space for both the settlement and its fields. It is, therefore, crucial to have an insight into the motives behind these colonizations. But the question why small groups made this choice, is difficult to answer. First of all the overall demographic situation

14 Yntema 1993a; Burgers 1998.

15 Yntema 1993a, 159.
16 Each hut is assumed to have been the dwelling of five to six persons. 


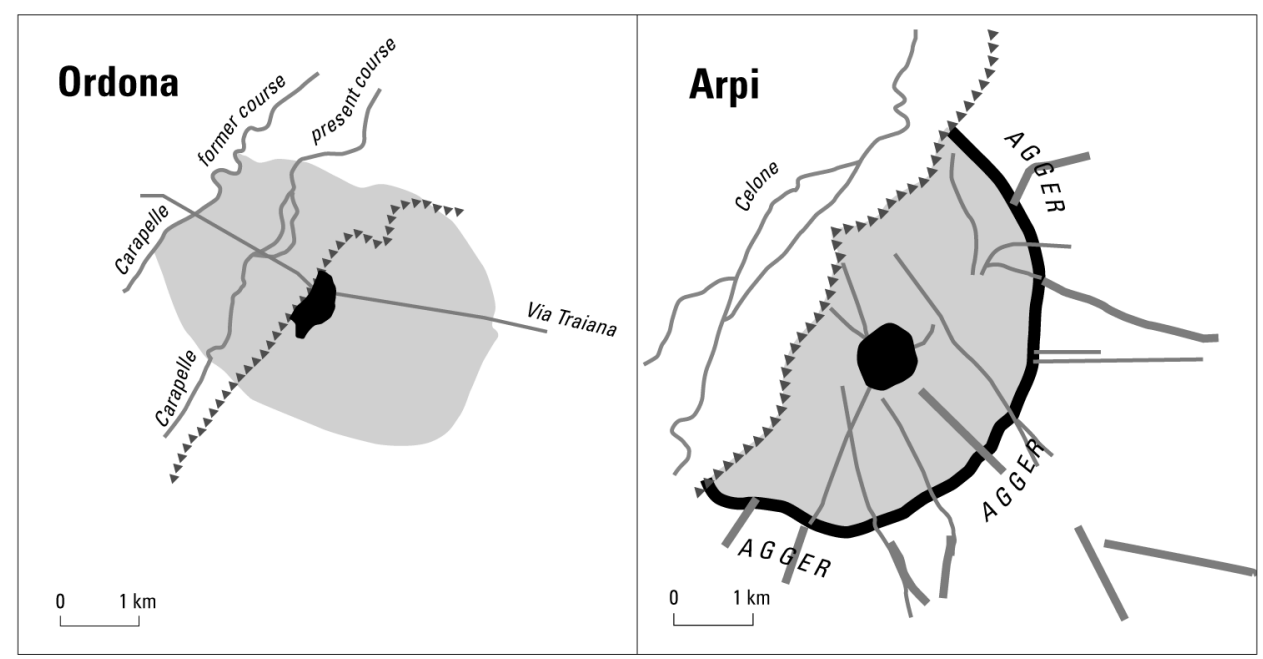

Fig. 4.3. Arpi and Ordona (Tavoliere, north-Apulia): Iron-Age dispersed settlement areas (7th-4th century BC) compared to early Roman urban phases (late 3rd-2nd century BC); adapted from Delano Smith 1979.

for 8th-century Salento should be made clear. When people leave their homes in order to colonize new areas in their own district, a population drain should be visible in the already existing settlements. This is indeed the case. A number of relatively small Iron Age settlements on the coast seem to have dwindled into insignificance and were abandoned during the second half 8th century BC. Torre Castelluccia in the Taranto district which features prominently in the chapter on the Bronze Age, was one of these sites. Other coastal sites of the Bronze Age and Early Iron Age, such as Taranto, Otranto and Brindisi continued to exist and may even have expanded. The same holds good for the few sites with a Bronze Age pedigree that were situated inland. Whilst Late Bronze Age nucleated Oria (c. 20 $\mathrm{km}$ from the Gulf of Taranto) may have had an extension of some 6 to 10 hectares, the admittedly highly dispersed Iron Age settlement covered some 70 to 90 hectares around 700/650 BC and can be assumed to have had hundreds of inhabitants. ${ }^{18}$ This notwithstanding, the district surrounding Oria which displays no traces of occupation in the final phases of the Bronze Age and the earliest phases of the Iron Age, was rapidly filled with new, initially small settlements during the later 8th century BC.

In the present state of research it seems that there were at least two, perhaps three factors that contributed to the relatively sudden colonization of inland Salento. The first factor is simply a population shift. Small groups living initially in relatively small settlements on the coast moved inland and founded new settlements on fertile soils. The second phenomenon is demographic growth. This has often been used as an easy explanation, but when suddenly a good handful of new settlements appear in a district where various larger settlements with earlier origins display signs of growth, the population is likely to have increased. This observation, for instance, holds good for the above-mentioned LBA site of Oria in the Brindisi plain that was to become a major tribal centre in the Iron Age. ${ }^{19}$ Two or three small groups of some 25 to 40 people may have left Oria in order to start a new life elsewhere. A third factor behind the colonization of inland Salento may, of course, be that formerly archaeologi-

17 Yntema 1993b

18 Yntema 1993a, 155.

19 The Greek 5th-century author Herodotus (VII, 170) even records a Messapian origo myth in which Oria (Hyriè) is considered to be the mother town of all the 'Messapian' settlements. There are several settle- ments at a relatively short distance from Oria that can be shown to have originated in the 8th century BC, e.g. Muro Tenente (10 km northeast of Oria), Muro Maurizio (17 km to the east of Oria), San Pancrazio Salentino (20 km southeast of Oria) and Manduria (10 $\mathrm{km}$ south of Oria). 

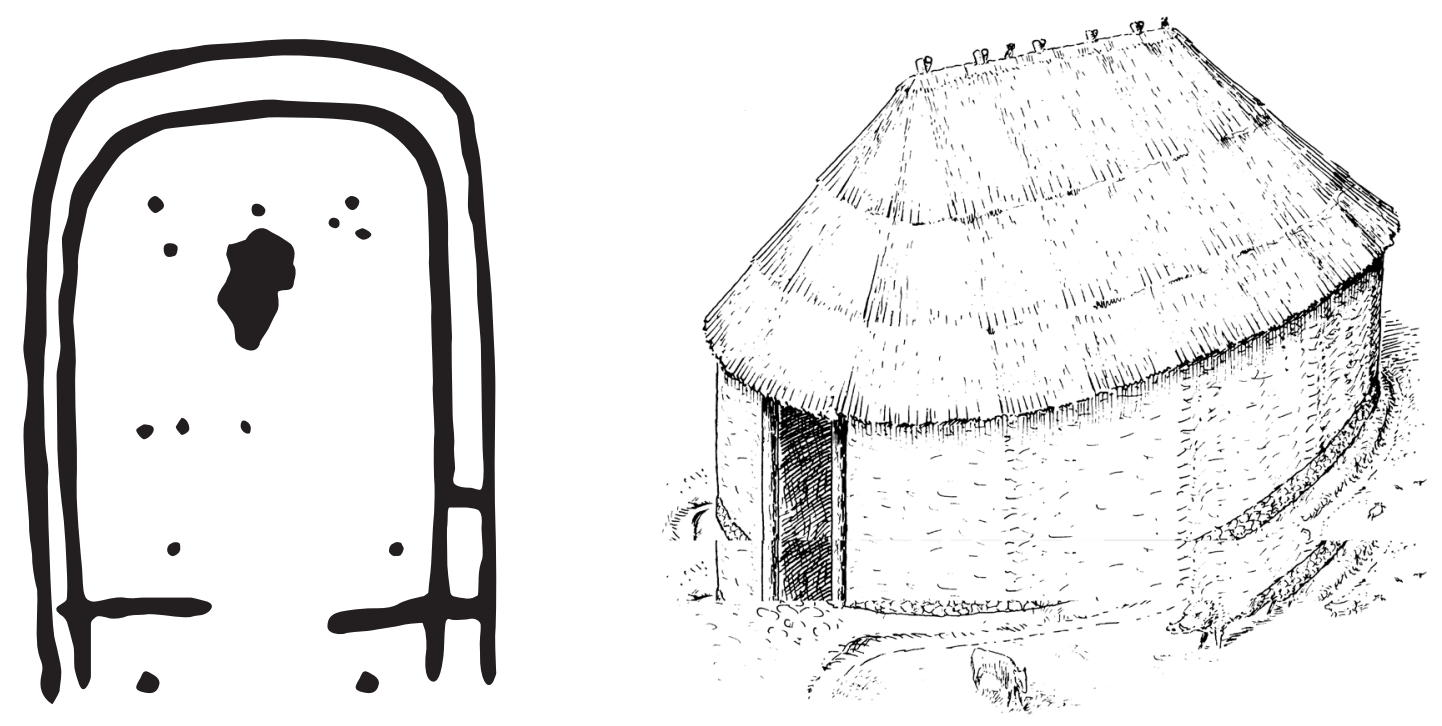

Fig. 4.4. (a) Salapia (Tavoliere district, north-Apulia): ground plan of hut, 9th-8th century BC (adapted from Tinè Bertocchi 1973); (b). Valesio (Salento) reconstruction of hut, 7th century BC.

cally invisible groups, such as pastoralist members of Salento societies, also contributed to the landscape infill of the inland plains by becoming sedentary, archaeologically traceable farmers. Both the massiveness and suddenness of the landscape infill, however, suggest that something drastic happened in the Salento societies around or shortly after the middle of the 8th century BC. The regional groups of this district were in a ferment that resulted in a remarkable short-distance displacement of people and completely different settlement patterns. ${ }^{20}$

These colonizations of inland areas, though their impact may have been modest during much of the 8th and early 7th centuries, were the first steps towards far-reaching ecological changes. When the number of settlements more than doubled in Salento in the period under discussion, natural environments were replaced by man-made landscapes at an unprecedented speed and on an unprecedented scale. These were only the beginnings of increasingly drastic infringements on the natural landscapes that culminated in Hellenistic and Roman times.

Now that the ins and outs of continuity and change in the Salento settlement patterns have been discussed, we may look for the reasons behind these remarkable changes. The drastic decision of a group to leave its settlement and start a new life elsewhere was not taken lightly. As we have seen above, two or more factors contributed to the substantial movement of people in the 8th century BC. There is, therefore, no simple, straightforward explanation for this phenomenon. Why did people move from the smaller settlements on the coast to an inland area? Perhaps because of the limited extent and the modest quality of agricultural lands close to the coastal settlements which may have showed signs of exhaustion. Perhaps also because there was a new and steadily intensifying phenomenon at sea: foreigners who spoke Greek and exchanged goods, but who tried to kill you, who plundered your stores and stole your women and animals when they got half the chance (see paragraph 4.3). But why leave the rapidly growing inland settlement of Oria for which there certainly was no piracy threat? Perhaps this was done exactly because this settlement grew so rapidly, because in approximately three to five generations the population had grown from one or two hundred to three or five hundred. This demographic growth almost certainly led to increased competition and the ensuing tensions between

20 Yntema 1993a, 160-161; Burgers 1998, 186-189. 
family groups and caused considerable social stress in the local societies. Small groups were thrown out or went away on their own initiative in order to build up a new existence elsewhere. They did so by clearing patches in the woods at a considerable distance from the settlement they came from. The 8th century BC, therefore, appears to be a period of substantial ferment and fission in the tribal societies of Salento.

In order to trace such phenomena both substantial settlement excavations and high intensity field surveys of various kinds are needed. As a result of field work in the Fossa Bradanica (the rift linking the Gulf of Taranto with north-Apulia) a comparable colonization can be observed. ${ }^{21}$ For other areas of southeast Italy, these surveys are often missing or still in their infancy. In the present state of research, therefore, there is no adequate evidence that helps us establish whether similar changes in the settlement patterns can indeed be observed all over southeast Italy. There are, however, signs that may be telling. A case study in the in the 'Peucetian' district around present-day Bari suggests that here a fair number of settlements are likely to have their origins in the 8th century BC. ${ }^{22}$ This information suggests that new areas were colonized here at approximately the same time as in Salento and the Gravina area of the Fossa Bradanica.

More solid information on colonization comes from Basilicata. It should be remembered that the settlements were predominantly near the coast in the Late and Final Bronze Age. Some of these settlements expanded enormously in the course of the later 9th and 8th centuries (especially Santa Maria d'Anglona and L'Incoronata) and became very large and highly dispersed. The impression from reports on the inland areas of Basilicata is that stable forms of settlement often made their appearance here from the late 9th onward, but especially during the 8th century BC. ${ }^{23}$ If indeed new areas were reclaimed for agricultural purposes in Basilicata, it was especially in the higher inland parts of that region. If there was a colonization in Basilicata comparable to that in Salento (and I believe there was), the higher parts of the region were colonized by people coming from the relatively low lying coastal areas. The uplands, moreover, were probably no terra incognita for the coastal groups of Basilicata. These mountainous areas contained important summer pastures which are likely to have been visited by those members of the coastal societies who were intensely involved in pastoralist activities.

Similar changes in settlement patterns cannot yet be traced in the Tavoliere plain of northern Apulia. Whilst the few Bronze Age settlements (e.g. Coppa Nevigata) at the brim of the Tavoliere were abandoned in the earlier phase of the Iron Age, the first new settlements came into being on the coastal lagoons of the flat district at the very end of the Bronze Age or in the beginning of the Iron Age. ${ }^{24}$ It is uncertain whether reclamations of inland areas were made in the following centuries. The fact is, however, that by the 8th century BC nearly all the major settlements of the later Archaic, Classical and Hellenistic times of the Tavoliere can be shown to have been in existence. ${ }^{25}$ Since their locations show a preference for well-watered, light arable soils close to watercourses, they were undoubtedly farmer's settlements, just as those that came into being in inland Salento in the 8th century BC.

The differences in size between the various hut settlements of southeast Italy and the fact that a substantial number of these must have been founded starting from an existing settlement with a long history suggest that there were differences of status between the Iron Age settlements. The Greek historian Herodotus (VII, 170) pictures the Salento site of Oria as the 'metropolis' of the Messapians. The

21 Small / Small 2005.

22 See Riccardi 1999. The case study concerns an inventory of sites in the area surrounding the large site of Rutigliano.

23 Bottini / Tagliente 1984, 111, Greco 1988, Rescigno 2001; Capozzoli / Osanna 2009, 141-142.
24 These were the settlements of Siponto-Cupola-Beccarini (e.g. De Juliis 1977b) and Salapia-Marana Lupara (e.g. Tinè Bertocchi 1973; Alberti et al. 1981)

25 For 8th-century origins of the site of Arpi, see Mazzei 1995, 41; for Ascoli Satriano, see Goffredo / Fico 2010, 29. 
archaeological evidence concerning that site indicates that Oria indeed ranked above all other settlements on the Salento isthmus. ${ }^{26}$ The Salento peninsula has been intensely studied. But it has also been observed that other districts of southeast Italy display similar signs of colonization and reclamation of formerly uninhabited areas. New, initially often small settlements, though economically self-supporting in many ways, must have depended socially, politically and mentally on the centre from which the colonists had set out to found a new settlement. There is, therefore, reason to assume that a distinct settlement hierarchy existed (or came into being) in almost every part of southeast Italy during the Iron Age.

In the preceding passage information on the outward appearance of the settlements has implicitly been given. They varied in size from one or two hectares for a newly founded settlement with two or three dozens of inhabitants to well over one hundred hectares with hundreds of inhabitants for a few settlements with a Bronze Age pedigree. The new colonist settlements developed fast and could cover some 15 to 20 hectares by the later 7th century BC (fig. 4.2 right). ${ }^{27}$ But all these settlements shared one important feature: they were all highly dispersed. In the case of the Salento site of Oria with a total population of perhaps four to eight hundred persons in the 7th century, a series of settlement nuclei, probably consisting of five to seven huts each, were strewn over some 70 to 90 hectares. The 180 hectares large plateau with the site of L'Incoronata-San Teodoro on the Gulf of Taranto and the 270 ha. large settlement area of 7th-century Canosa in central-north Apulia are other examples of this highly dispersed character of Iron Age settlements. ${ }^{28}$

The most extreme case can be found in the north-Apulian plain. Around 600/550 BC an approximately $2.00 \mathrm{~m}$. high and $7 \mathrm{~km}$ long agger enclosed the eastern side of the important site of Arpi, whilst the western side was protected by $6 \mathrm{~km}$ of steep banks of the river Celone (fig. 4.3): they surrounded a settlement area of approximately 1.000 ha. The length of these obstacles (agger and steep banks) was, of course, far too great to serve as a defence against the aggression of neighbouring groups: the few hundreds of inhabitants were certainly unable to defend the c. $13 \mathrm{~km}$ long perimeter of Arpi effectively. The agger, therefore, clearly served other purposes.

The enormous extension of the settlement areas indicates that these were not exclusively the places where the inhabitants had their dwellings. Their sheer extension shows that they were far too large for this. Since the various groups of huts were often hundreds of meters apart, the 'empty' areas between the habitation clusters are likely to have been intensely used for other purposes than habitation. They probably contained the paths that linked the hut clusters, the fields, the compounds for animal husbandry and possibly a central open area where the leaders of the local family groups and their retinue discussed issues of common interest and where the members of the local community may have performed communal rites and feasted together. Family burial plots were part of the same manmade landscape. Each Iron Age settlement of southeast Italy, therefore, was a kind of human micro-cosmos surrounded by natural environments. It was a clearing in the natural vegetation and consisted of dwellings, fields, animal compounds and burial sites.

These manmade environments were surrounded on all sides by forests and shrubbery (macchia). These large, 'wild' areas were almost as vital to these societies as the manmade landscape of the settlement area. They supplied firewood and building materials, were foraging areas for swine, sheep, goats and cattle and provided additional food (e.g. wild fruit and wild plants; game such as hares, red deer and wild boar). ${ }^{29}$ The dividing line between manmade landscape and natural landscape may have

26 Burgers 1998, 190.

27 Yntema 1993b.

28 For L'Incoronata, see Pelosi 1991 and Giardino / De Siena 1999; for Canosa (Canusium in Roman times) see Goffredo 2010 .
29 Iron Age bone samples contain often a relatively large percentage (up to 6\%) of red deer (Cervus elaphus), whilst the bones of pigs can as least partly be taken as belonging to the wild boar (Sus scrofa). 
been clearly marked. Earthworks (usually of much more modest length than the 6th-century agger of Arpi) may have served this purpose. They could have been crowned by thorn bushes or even palisades. If so, they also served to keep the deer and wild boars off the fields and the wolves and bears off the animal husbandry.

During the 9th and 8th centuries BC the dwellings in the Iron Age settlements were invariably huts. The ground plans of these dwellings show only slight variations. Mostly these were oval. The huts were all more or less of the same size. They currently had a length between approximately 5.00 and $7.00 \mathrm{~m}$ and a width of 3.50 to $4.00 \mathrm{~m}$. In some cases they had a straight front and a rounded backside (fig. 4.4a). Their construction was simply wattle and daub with a stone plinth and a framework consisting of vertical posts. The roofs of the huts were made of thatched beams (fig. 4.4b). Huts with these characteristics can easily be constructed by a family group and are unlikely to have had a long life. Ceramics recovered from hut floors suggest that the average life expectancy of such a structure in southeast Italy varied between 20 and 30 years. This corresponds to approximately one generation, i.e. the average life expectancy of a household..$^{30}$

Burial sites were usually very much a part of the highly dispersed settlements of Iron Age southeast Italy: we have seen that they were often within the large settlement area. ${ }^{31}$ In the Iron Age the deceased were buried close to the living. Babies (and perhaps still-borns) could even be buried underneath the floor of the hut in which they had been brought into the world. The spatial distribution of tombs over the settlement is very similar to that of the dwellings. They often occur in small clusters that can be hundreds of meters apart. Like the clusters of huts, these clusters of graves probably represent family groups. Although it is often difficult to connect groups of huts with clusters of burials (only small parts of the large settlement areas have been excavated), one may suggest that often the deceased of the family group or clan were buried in the same family plot within the settlement that also contained the group's huts and fields.

A short summary of the data and the interpretations presented above supplies the following concise and necessarily generalized picture of settlement and landscape of southeast Italy in the period under discussion. In the Iron Age sedentary forms of settlement expanded considerably in many parts of southeast Italy. The resident population increased; demographic growth was probably substantial. As a result of this phenomenon, social stress is likely to have occurred, especially in the coastal areas of southeast Italy where much of the population had lived since the Later Bronze Age. It is moreover clear that in the course of the 9th, but especially during the 8th centuries BC, new areas were reclaimed for human activities on a relatively large scale. These were often in non-coastal environments. While the drive behind such actions may have been of a social nature (social stress) and could be triggered by external factors (e.g. raids by Greek ships on small coastal settlements), they resulted in the foundation of new farmer communities. Some of these may initially have depended on settlements with Bronze Age roots. As we have seen above, there was definitely a distinct settlement hierarchy in the later Iron Age. Since most of these new communities grew substantially in the first hundred years of their existence, they may have become relatively independent entities, being at a considerable distance from the 'old' settlements. This may have entailed a redefinition of territorial notions. ${ }^{32}$

30 This is approximately the period that covers the time between the founding of a new family and the moment the last child leaves the hut.

31 The exception to this rule is the southeast Salento peninsula. Although this district has been intensely investigated, no Iron Age burials have been discovered here. The earliest Salento tombs date to the very end of the 7 th or the early years of the 6th century BC.

32 Burgers 1998, 191, note 15. 

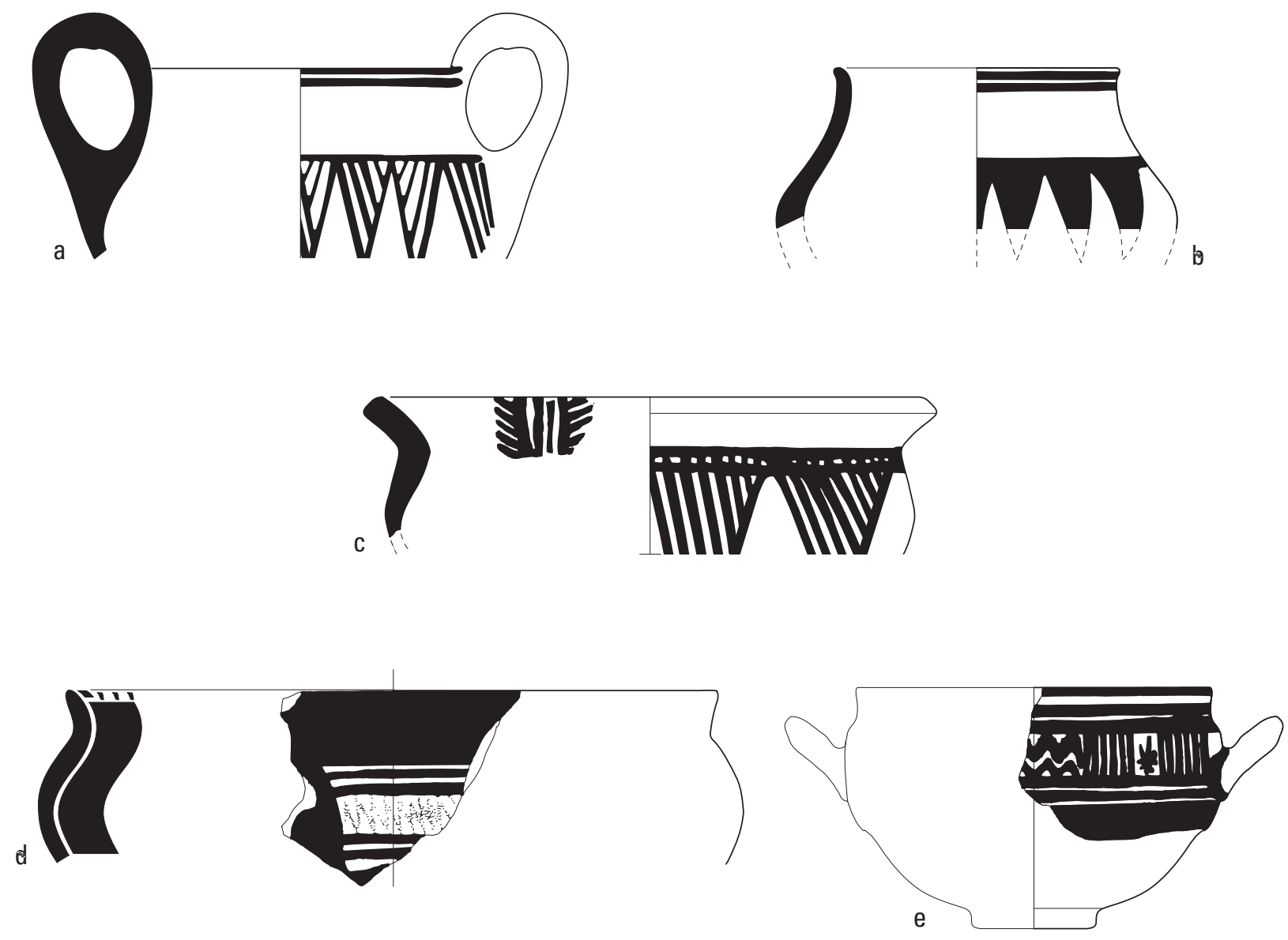

Fig. 4.5. Otranto (Salento district, south Apulia): (a-c) Albanian Devoll wares, late 9th-1st half of the 8th century BC and (d-e) Corinthian Middle Geometric wares (after D’Andria 1985 and 1995).

There is indeed good reason to assume that in the course of time new territories were carved out. This happened in an existing political landscape of which the general outline had been defined in the Bronze Age. The 'old' centres sometimes continued to be important: some of these were high up in the regional settlement hierarchy of the Iron Age. From the later 8th century onward, however, a partly new political landscape came into being in which the 'new' settlements played an increasingly significant role. Some of the 'old' settlements lost their important position, while some of the 'new' settlements became increasingly important and joined the ranks of major regional centres in the late phases of the Iron Age. ${ }^{33}$ The traces of this new political landscape continued to be present in the regional societies till well after the Roman conquest of southern Italy.

33 The earliest finds from the intensely researched settlement of Cavallino di Lecce date to the 8th century $\mathrm{BC}$; by the middle of the 6th century $\mathrm{BC}$ it was a (or perhaps the) major centre in the central part of the Salento peninsula (D'Andria 1977, 1988, 2005; Pancrazzi 1979). A similar case was Serra di Vaglio in upper Basilicata. Although the first faint traces of human presence here go back to the Final Bronze Age, Serra di Vaglio did not become a settlement of some substance before the 8th century BC. By the late 6th century BC it was one of the most important settlements of Basilicata and is often believed to have been the tribal centre of the whole Nomen Lucanum from the 5 th or 4th century BC onward (cf. Greco 1980, 1991). 


\section{3 R A I D ER , T R A D E R A N D M I G R A T S}

In the preceding section on settlements and landscape Greeks briefly appeared on the stage of the Italian Iron Age. Although the contacts between Greece and other areas of the eastern Mediterranean on the one hand and southeast Italy on the other hand probably never completely ceased, the material evidence for such contacts is thin for the 11th to 9th century BC. ${ }^{34}$ From the end of the 9th century $\mathrm{BC}$ onward the signs of contacts between southeast Italy and the Greek world, however, become increasingly numerous. The earliest Greek Iron Age wares in Italy stem from the site of Otranto in the Salento peninsula. This is Italy's easternmost settlement and has an occupational history going back to well into the Bronze Age. ${ }^{35}$ In settlement contexts with large numbers of locally produced matt-painted and impasto wares some 600 fragments of Greek pottery have been found which have been dated between the late 9th and the middle of the 8th century BC. ${ }^{36}$ These are predominantly painted wares of Corinthian origin (Corinthian Middle Geometric wares; fig. $4.5 \mathrm{~d}-\mathrm{e}$ ), but undecorated transport vessels with a typically Corinthian fabric are also present in the same Iron Age strata. ${ }^{37}$ The very same contexts of Otranto also contained modest quantities of the so-called Devoll wares from present-day Albania and Epirus (fig. 4.5 a-c). ${ }^{38}$ This suggests that the contacts were not purely bilateral, but that at least three districts around the Ionian Sea participated in an exchange network: (a) the 'Corinthian' orbit with the Gulf of Corinth, (b) north-western Greece/south-Albania and (c) the Salento peninsula. Perhaps eastern Sicily should be added to this list. By passing through the Strait of Messina, moreover, the Tyrrhenean exchange network could be entered that had its principal focus on the island of Ischia/Pithekoussai. ${ }^{39}$

In the second half of the 8th century the Greek ceramics that reached Salento grew into a flood. While Otranto is hitherto the only site of southeast Italy with a substantial quantity of early 8th-century imports, ${ }^{40}$ the Corinthian Late Geometric wares and Protocorinthian pottery of the later 8 th and early 7th century BC are widely distributed. ${ }^{41}$ These imported ceramics are found in large parts of the Salento peninsula, in the coastal zones of Basilicata and in northern Calabria, but are conspicuous by their absence on the Adriatic coast of southern Italy north of Brindisi. ${ }^{42}$ Otranto, however, received the lion's share of these Greek wares: thousands of pieces of imported Greek pottery have been found there. In Otranto, moreover, the variety of Greek 8th- and 7th-century imports is greater than at most other sites: in addition to the Corinthian wares, there are the so-called SOS amphorae (Attic or Euboean), amphorae from western Asia Minor and painted wares from Greek islands in the Aegean. ${ }^{43}$ Both the large quantity and the great variety of imported ceramics suggest that Otranto held a special position in the maritime exchange network spanning the areas surrounding the Ionian Sea.

34 See, for instance, Bietti Sestieri 1985.

35 Orlando 1983

36 D’Andria 1995.

37 These are storage vessels have the characteristic Corinthian A fabric. Among these the amphora is by far the most dominant form, but there are also fragments of large pithoi and jugs with the same fabric.

38 These are handmade, matt-painted wares that are distributed over present-day central and southern Albania and northwest Greece (e.g. Kilian 1972; Hochstetter
1982; Votokopoulou 1986).

39 Ridgway 1992 and 1993.

40 i.e. Albanian Devoll pottery, Corinthian Middle Geometric and undecorated wares with the characteristic Corinthian A fabric. Two pieces identified as fragments of Corinthian Middle Geometric cups were found at L'Incoronata di Metaponto in Basilicata (Orlandini 1976; Denti 2010).

${ }_{41}$ Dehl 1984; D’Andria 1985, 1995. 


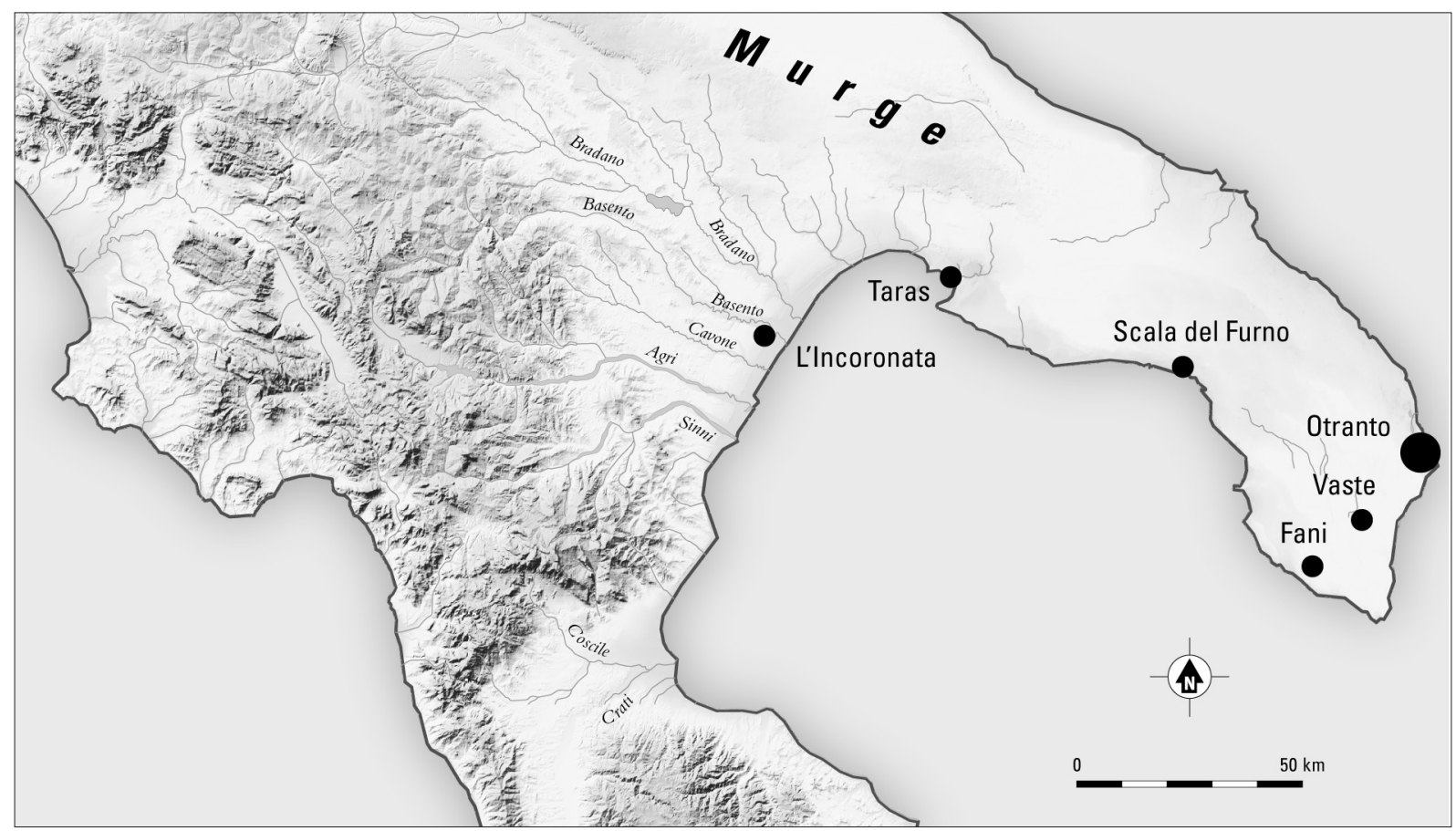

Fig. 4.6. Southeast Italy: distribution of Greek wares of the early to middle 8th century.

Greek Iron Age ventures towards the west have spawned a huge bibliography. Often archaeologists and ancient historians put their faith in the ancient written sources and believed that Greeks indeed founded Greek towns in southern Italy as early as the 8th century BC. Some of the Greek ceramics found in Italy appeared to precede the foundation of Greek poleis. Obviously, it was decided, trade went before the flag. It was, moreover, quite plausible to assume that the Greeks did not colonize a terra incognita but had a fairly good notion of the geography and the many qualities of the western world. The phase preceding Greek settlement in southern Italy has therefore been coined with the term 'precolonization phase', whilst the phase with 'proof' of Greek settlement (mostly consisting of Greek-style burials) in southern Italy and Sicily has been described as the "colonization phase'. ${ }^{44}$ In recent times the data regarding Greek contacts with southern Italy have increased enormously and new, more nuanced explanations have been proposed. ${ }^{45}$ On the basis of new archaeological evidence it has been demonstrated that pre-colonization cannot be clearly separated from the 'classic' colonization phase. Both terms appear to cover a wide variety of forms of Greek presence which have relatively little in common. ${ }^{46}$ The use of these two concepts, therefore, appears to be fairly problematical. The definition of the term and the notions and prejudices attached to it will be discussed below in some detail.

42 The sites with Greek Late Geometric and Protocorinthian wares near the Adriatic coast are Valesio (Yntema 2001), Muro Tenente and San Pancrazio Salentino (Burgers / Maruggi 2001). The only site with such wares north of Brindisi is Castelluccio (Burgers / Recchia 2009, 79; Semeraro / Notarstefano 2011). This means that similar wares can be expected in Brindisi.

43 For Otranto, D’Andria 1979, 1990 and 1995. A comparable variety of Greek ceramics is encountered in 8th-century Pithekoussai (Ridgway 1992) and in 7th-century L'Incoronata di Metaponto (e.g. Greci sul Basento).

44 Ridgway 1992.

45 Especially Carter 1993.

46 Osborne 1998, Yntema 2000, Stein-Hölkeskamp 2006, Momrak 2007; for a very differrent view on Greek colonization, see Greco 2011. 
But let us first consider the nature of the Greek presence in southeast Italy during the late 9th and the 8th century BC (i.e. the earliest phase of regular contacts between Greeks and people from Italy) in order to construct an image of what may have happened there. Hitherto imported Greek ceramics from this period have almost exclusively been found at the site of Otranto (fig. 4.6). The numerous finds here indicate that contacts with these foreigners were both fairly frequent and relatively intensive. This suggests that the settlement was a port of call and that Greeks came here in order to exchange articles with the local population. In the perception of the Iron Age Greeks, Otranto (like the island of Corfu) was only slightly beyond the threshold that separated their world from the world of 'the others'. ${ }^{47}$ But why the concentration of Greek imports at Otranto in the earlier 8th century? Of course, this settlement was a first step from the Balkans towards the Tyrrhenean Sea and the island of Pithekoussai in the Bay of Naples which was an emporion (trade station) from about 770/760 onward. ${ }^{48}$ As we have seen, the second step towards the Tyrrhenean was probably eastern Sicily. Otranto, therefore, was a crucial link in long distance exchange networks from the late 9th or early 8th century onward. Its inhabitants may well have participated in networks of guest-friendships that also involved the Greek sailors. The settlement was a port of call for Greek traders; its inhabitants assisted these foreigners by providing water, food and shelter.

Otranto, however, may well have been more than just a first step towards the Tyrrhenean and a vital link in an exchange network spanning the Ionian Sea. It is unlikely that the Greeks who visited Italy in the 8th century BC were exclusively peaceful traders. The Homeric poems tell us that trading, raiding and piracy went hand in hand in the Iron Age. In these, the achievement of kleos ('fame') by various means, including raiding and travelling beyond the threshold of the Greek world, is part and parcel of the aristocratic ideology. ${ }^{49}$ Greeks, therefore, may have raided coastal settlements around the Ionian Sea and may have captured Greek and indigenous ships, if Homer's passages on this matter are not purely fictitious. Therefore, Otranto was not just an important port of call for ventures towards the west: it could also have been a base for other considerably less enlightened activities. These may, for instance, have included the quest for booty and slaves by means of piracy and raiding.

From the late 8th century BC, however, imported Greek ceramics are found in almost every site on the Strait of Otranto and the Gulf of Taranto. This observation holds good for both fine wares and transport vessels. Obviously, contacts with Greeks in this part of Italy intensified very substantially and may even have been maintained on a regular basis by quite a number of Italic settlements. Since these Greek ceramics are also found in inland settlements of southeast Italy, ${ }^{50}$ indigenous exchange networks played a role in the distribution of these imported wares. Otranto, however, continued to hold a special position. The large number of Corinthian A amphorae, Corinthian painted wares and the storage sheds in late 8th- and early 7th-century strata of this site have led to the supposition that a group of Greeks actually settled here.$^{51}$ If Greeks really lived at Otranto during this period (and I think this is plausible), they lived within, or at the periphery of, an indigenous settlement.

The site of Otranto has not produced any hard evidence of Greek presence in the form of Greek graffiti or burials which differ in several aspects from the indigenous mortuary practices observed in Iron Age southeast Italy. The claim of a more or less permanent Greek presence here is exclusively based on circumstantial evidence. From the first half of the 7th century onward, however, several sites of southeast Italy start to display a series of cultural features that have no predecessors in the 8thcentury societies of this region. Among these are: (1) a new type of dwelling, (2) new types of burial

7 Malkin 1998.

48 See Ridgway 1992.

49 Crielaard 1996.

50 For instance at Monte Sannace (Scarfî 1963, 130), Ali- anello (Bianco / Tagliente 1985), San Pancrazio Salentino (Maruggi/Burgers 2001, 85), Muro Tenente (Burgers / Yntema 1999, 125, fig. 12.10).

51 For instance, D’Andria 1996. 


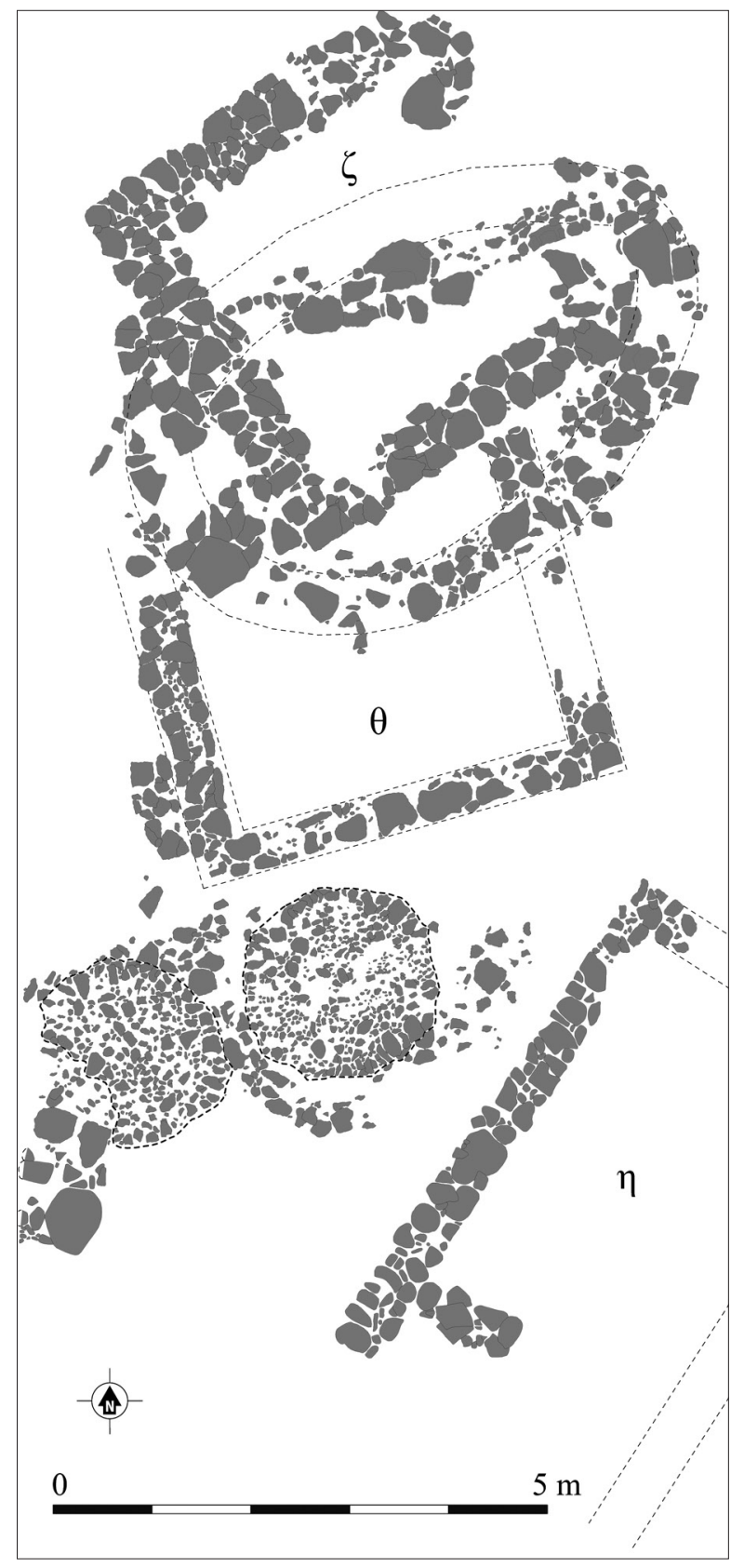

Fig. 4.7. Early houses in southeast Italy: (a) plan of houses at L'Amastuola (after Maruggi 1996); (b-c) reconstructions of a house and the silos at L'Amastuola, mid 7th century BC.
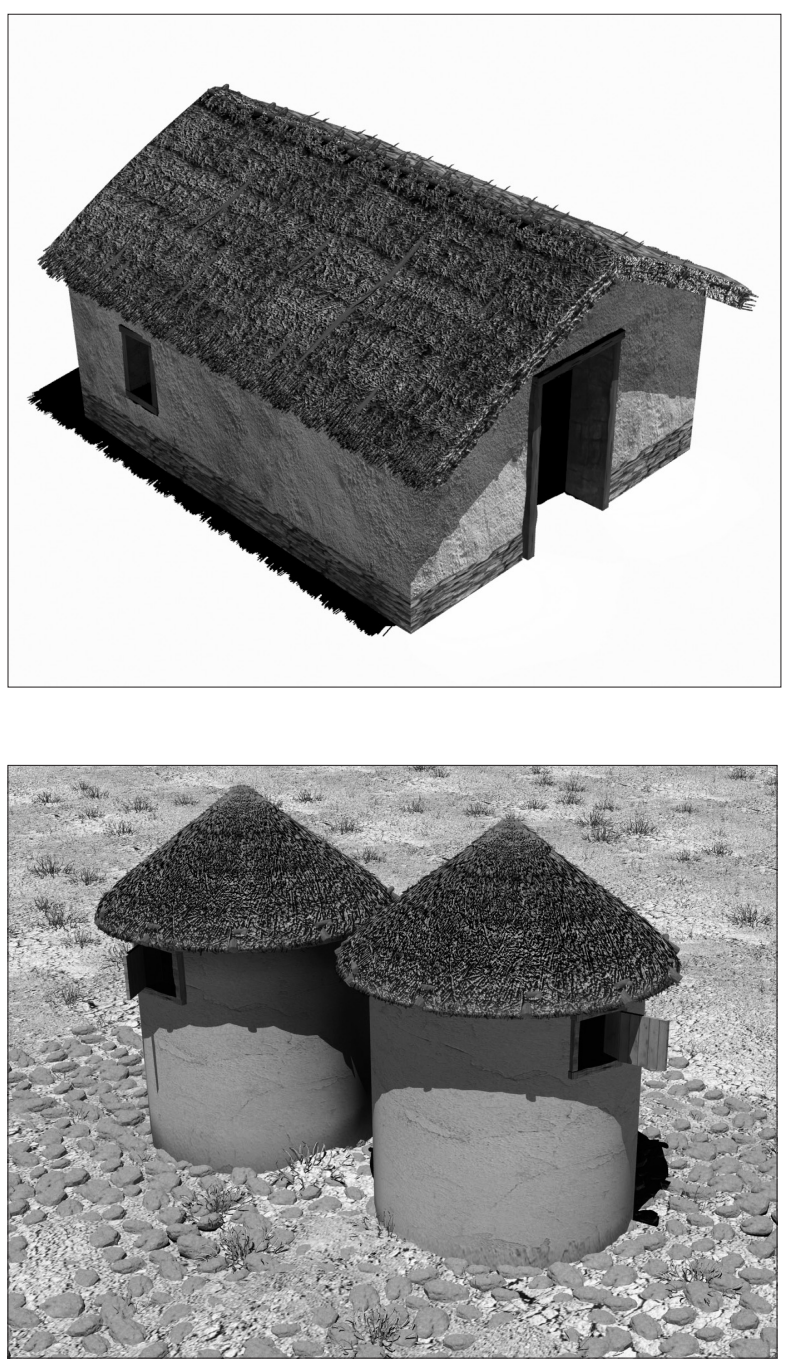

customs and (3) drastic innovations in the sector of craft. The new type of dwellings and the new burial customs will be shortly discussed here. ${ }^{52}$

Huts continued to be the principal form of dwelling in large parts of southeast Italy to within the first half of the 6th century BC. But in addition to these, a new architectural form made its appearance, probably as early as the second quarter of the 7th century BC. The newly introduced type of dwelling was the house, having a rectangular ground plan and one or more rooms (fig. 4.7a). The lower part of the walls of these buildings consisted of cobble-stones from near-by rivers or irregular blocks of local limestone. There is usually little information about the superstructure. The upper part of the walls probably consisted of mudbrick sustaining beams forming a thatched roof (fig. 4.7b). The most striking

52 The innovations in craft will be discussed in the below section 4.6. 

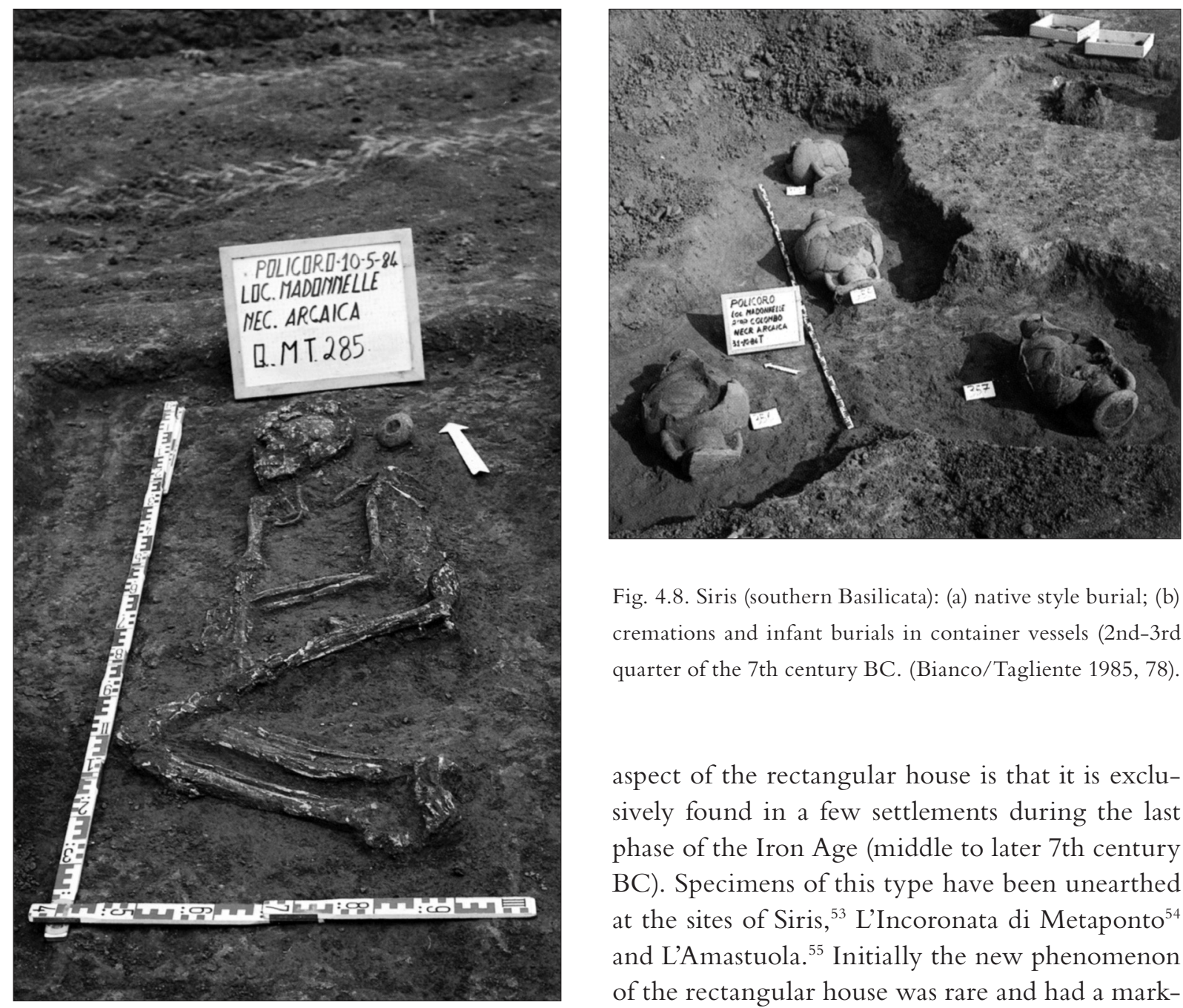

Fig. 4.8. Siris (southern Basilicata): (a) native style burial; (b) cremations and infant burials in container vessels (2nd-3rd quarter of the 7th century BC. (Bianco/Tagliente 1985, 78).

aspect of the rectangular house is that it is exclusively found in a few settlements during the last phase of the Iron Age (middle to later 7th century BC). Specimens of this type have been unearthed at the sites of Siris, ${ }^{53}$ L'Incoronata di Metaponto ${ }^{54}$ and L'Amastuola. ${ }^{55}$ Initially the new phenomenon of the rectangular house was rare and had a markedly coastal distribution.

The same three coastal settlements that show the new form of dwelling (Siris, L'Incoronata and L'Amastuola), also display strikingly new features in burial customs. ${ }^{56}$ These made their appearance in the first quarter of the 7th century BC and became slightly more common from c. 670/660 onward. These three settlements have necropoleis showing characteristics that differ in many respects from earlier burial sites in southeast Italy. The first new feature was that the new type of burial sites was definitely outside the settlement area, whereas traditionally the burial grounds and habitation areas were not rigidly separated. A second novelty was that they became in due course substantial graveyards with a considerable density of burials and differed notably from the traditional, dispersed clusters of tombs. ${ }^{57}$ The necropoleis of this new type, moreover, were often used for a relatively long time. They were, therefore, stable elements in the human landscape. The necropolis of L'Amastuola near Taranto, for instance, is estimated to have contained more than 250 graves (nearly all robbed) and spanned a period of approximately two centuries. ${ }^{58}$ Siris has the most complete and relatively well-published series of

53 Tagliente 1985.

54 Carter 1993; Lambrugo 2003.

55 Maruggi 1996; Burgers / Crielaard 2007 and 2011.

56 For the 7th-6th century necropoleis of Siris, see Berlingò 1986 and 1993; for L'Incoronata, see Giardino /
De Siena 1999, 35; for L’Amastuola, see Maruggi 1996.

57 Within these new graveyards family groups can usually be recognized.

58 Burgers / Crielaard 2011, 105-114. 
burials of these three coastal necropoleis of the 7 th century BC. ${ }^{59}$ In fact the settlement had at least two substantial burials grounds which are some 600 meters apart. ${ }^{60}$ The southwestern Schirone necropolis was only partially excavated (64 tombs recovered), the western Madonelle necropolis contained at least 450 burials. Initially the burials rites within these two contemporary cemeteries varied considerably: cremation in a large pot, inhumation in a trench or inhumation in a large jar (fig. 4.8). The quantity of objects in the graves is invariably small when compared to the tombs of traditional Italic type. The burial gifts mostly consisted of a few Greek pots, aryballoi and wine cups being foremost among them. The containers in which the ashes of the adults or the bodies of the children were deposited, could be Greek as well. Among them are amphorae from the eastern part of the Aegean (e.g. Chios and Clazomenae) and Corinthian A amphorae, but both the cremated remains of the adults and the bodies of children (invariably inhumation) could also be interred in large impasto containers of traditional type that had been made in large quantities in southeast Italy since the Bronze Age.

Burials of these new and unusual types have also been discovered at other sites of the area under discussion. The earliest grave displaying an unusual character stems from Taranto and can be dated to approximately 700 BC. ${ }^{61}$ In principle this could be a Greek sailor's grave, but Taranto has produced at least six more graves of this type. These, moreover, were the earliest burials in what would become the large necropolis of the Greek polis of Taras. ${ }^{62}$ Furthermore, very similar small grave groups with predominantly middle and late Proto-Corinthian wares (often aryballoi among them) have also been reported from the coastal sites of Torre Saturo and Brindisi in south Apulia. ${ }^{63}$

In the first half of the 7th century, therefore, a new type of burial site with new types of burial rites made its appearance in southeast Italy. These new features are exclusively found in coastal settlements. Some of these grave groups were long-lived and developed into fairly large necropoleis (Siris, L'Incoronata, L'Amastuola, Taras), others were small and covered only one or two generations (Brindisi, Torre Saturo). These represent a new phenomenon that was fairly widespread in the area under discussion. Its intensity varied substantially. But since the new burial rites are closely paralleled in Aegean areas, they suggest - together with the new type of dwelling and drastic innovations in craft (see paragraph 4.6) - that before the middle of the 7th century small groups of Greeks started to live in various parts of the coastal strip of southeast Italy. Some of these groups continued to be small and vanished from the archaeological record (e.g. Brindisi), others grew rapidly, especially after the middle of the 7th century BC (e.g. Siris, L'Incoronata, L'Amastuola).

Are these new and unusual features actually the earliest traces of Greek colonization in southeast Italy? The answer depends very much on the way the term 'colonization' is defined. 'Greek colonization' is now sometimes written with a question mark. ${ }^{64}$ At present it is, of course, common knowledge that the image we had of Greek colonization till well within the 1990s, heavily depended on what the ancient Greek authors told us about this subject. Because their stories were put into writing at least some 150 to 200 years after the alleged foundation (ktisis) of a Greek colony (apoikia) took place, they are evidently based on oral history and on the views much later Greeks held on the origins of their towns. Foundation stories of colonies as told by ancient Greek authors should, therefore, be considered as origo-myths.

59 Berlingò 1986, 1993.

${ }^{60}$ At Siris there were also tomb groups dating to the same period on the later acropolis and to the southeast of the settlement (Giardino / De Siena 1999).

${ }^{61}$ This Taranto burial (cremation, whilst southeast Italy has inhumations in the Iron Age) contains a globular Early Proto-Corinthian aryballos and a cup; see
Dell'Aglio 1990, 57.

62 Neeft 1994.

63 For Torre Saturo (often identified with the settlement of Satyrion mentioned in ancient written sources), see Lo Porto 1964a; for Brindisi, see Lo Porto 1964b.

64 Osborne 1998. 
Whereas the genesis of the Greek apoikiai of Taras, Metapontion Siris and Sybaris took some 60 to 100 years, the origo myth transformed this process into one single event. The image produced by ancient Greek authors was, moreover, strongly processed and changed under the influence of west- and southEuropean colonial experiences of the 19th and 20th century AD. While there may be some superficial analogies between both types of overseas ventures in their earliest phase with first contact situations, the differences are highly apparent for the later phases. During the Iron Age, for instance, there was no Greek superiority over indigenous populations of southeast Italy and the ancient history of this region teaches us that if this was ever the case, the balance was rapidly restored. ${ }^{65}$ The cliché of Greek superiority in 'colonial' situations, moreover, appears to be mainly the result of an unhappy marriage between the Athenian post-Persian war triumphalism ${ }^{66}$ and the projection of west-European colonial notions of the 19th and 20th centuries on the ancient world. ${ }^{67}$ If we wish to retain the term colonization (but the more neutral term 'migration' should be preferred), we should realize that the evidence produced by the burials discussed above suggests that there were various forms of early Greek presence in southeast Italy and that these presences differed enormously from what we believed them to be in the past (i.e. a patently Greek town outside the original Greek core area).

Basically the term 'colonization' derives from the Latin word colonus meaning 'farmer'. Colonization, therefore, can be defined as: 'the process of taking possession of the soil in an entirely new environment'. ${ }^{68}$ The use of force against resident populations is usually part of this definition. If we stick to this aspect in the definition of the term, the historically attested Greek colonizations of the later 8th and earlier 7th centuries BC were definitely not colonizations. Before the middle of the 7th century BC the 'Greek colonies' of southeast Italy were often no aggressive, patently Greek strongholds amongst unfriendly and backward natives. Perhaps this image of strong Greek-native opposition holds good for the 6th and 5th centuries BC (see chapter 5). But during much of the 7th century BC the settlements of Sybaris, Siris, Metapontion and Taras are likely to have been settlements with a mixed population, where peaceful coexistence and close cooperation between Greek migrants and inhabitants with Italic roots was much more common than fierce Greek-native conflicts. ${ }^{69}$ Till about 650/630 BC these four settlements that were to become Greek city states in the 6th century BC, did not differ much from L'Amastuola, L'Incoronata, Otranto or Brindisi that have never been perceived as Greek colonies. The varied character of these Greek presences that emerges from the archaeological evidence recovered since the 1970s, will only be succinctly discussed here. ${ }^{70}$

The paucity of Greek style tombs dating before c. 660/650 BC suggests that initially only small quantities of Greeks lived in southeast Italy. Some of these lived in indigenous settlements (Brindisi, Otranto), others may have been among the first inhabitants of an entirely new settlement at the fringes of an indigenous polity (e.g. Siris, Metapontion). ${ }^{71}$ Because these groups were small and lived far from their kinsmen and basic resources, they must have been dependent on the native groups living nearby.

65 Whilst Greeks may have had better forms of organization and better military tactics during a part of the 6th century, the disastrous defeat of the Tarantines at the hand of the Messapians in c. $473 \mathrm{BC}$ and the rise and threatening character of the Lucanians in the later 5th century indicate that if there was any Greek organizational and military superiority, it was fairly short-lived.

66 Hall 1989.

67 Van Dommelen 1997.

68 Cf. Carter 1993.
69 Yntema 2000.

70 For detailed discussion on the evidence for the character of Greek presences in southeast Italy between the late 8th and the late 7th century BC, see Yntema 2000.

71 Two settlement clusters of comparable type (2nd to 3rd quarter of the 7th century) were found underneath Archaic-Classical Metapontion (sites of MetapontoAndrisani and Metaponto-Lazzazzera; for these sites, see Greci sul Basento, 199-212; De Siena 1986 and 1996). 
On the strength of the present evidence the first Greeks to settle in southeast Italy must have been traders, craftsmen, mercenaries and other types of adventurers. They were dependent on, and, therefore, closely allied with native groups.

Such small, fairly successful Greek groups, closely connected with both indigenous polities and the Greek trade diaspora, may well have induced others to migrate. The socio-political situation in Greece was not particularly stable during the first half of the 7th century BC. ${ }^{72}$ Migration to the fertile lands of southern Italy, therefore, could well be a welcome alternative from civil strife and a hand to mouth existence at home. Because both Greek and indigenous inhabitants were in regular (if not constant) contact with each other, a considerable degree of integration is likely to have taken place. Intermarriage between people belonging to different ethnic groups may well have occurred. The radical opposition which is sometimes believed to have characterized Greek-native relations in the early 'colonization' phase, should be discarded. The small groups of new Greek settlers would not have survived in southeast Italy without substantial assistance from the neighbouring indigenous groups. ${ }^{73}$

The archaeological record of southeast Italy suggests that the number of people who had Greek roots or, in any case, saw themselves as Greeks and lived in coastal settlements of southeast Italy on a more or less permanent basis, was gradually increasing in the second quarter of the 7th century. The appearance of various Greek-style burial grounds (e.g. L'Amastuola) from about the second quarter of the 7th century onwards indicates that these Greeks sometimes lived in small, coherent groups. Natives who closely associated themselves with these foreigners may also have been part of the same group. For the Greek-style necropoleis of Siris graves even of non-Greeks have been reported (fig. 4.8). ${ }^{74}$ The excavations at L'Amastuola suggest that this settlement had native origins. From 680/670, however, it appears to have developed into a mixed community in which people with Italic pedigree and Greek migrants lived together: a to all appearances Greek burial could have patently native headstone here. ${ }^{75}$

The small, but steadily growing Greek groups of southeast Italy may also have played a role in the relations between various indigenous groups. If 'their' Italic settlements and their livelihood were being threatened by neighbouring native groups, they may well have taken part in military actions of the indigenous group in which they lived. In view of the military and organisational innovations in the 7th century Greek world, ${ }^{76}$ a relatively small group of Greek hoplites could have exerted a substantial influence on the power play between competing indigenous groups in southeast Italy. The relations between Greek and native groups, therefore, are likely to have been rather varied. Greeks are likely to have assisted natives against other Greek groups or other native communities and vice versa.

The nature of the relations between these newcomers and the local population was equally varied. In the case of Siris, the migrants shared a completely new settlement with individuals who might well have belonged to local Italic groups. ${ }^{77}$ At L'Incoronata they shared a part of a somewhat condensed settlement in a peripheral area of the originally highly dispersed indigenous settlement. ${ }^{78}$ Otranto may have been a very similar case. The location of the graveyard (well outside the indigenous settlement) suggests that both Brindisi and Taranto also had small Greek communities living in, or at the periphery of, an indigenous settlement. ${ }^{79}$ At L'Amastuola Greeks came to live in a native settlement that had been founded some 50 years earlier and mixed with the indigenous population.

Although these foreigners were initially present in only modest numbers, they were indeed a phenomenon that was new to the region. But the presence of people having a Greek material and a Greek cultural background intensified notably during the second half of the 7th century BC. Part of

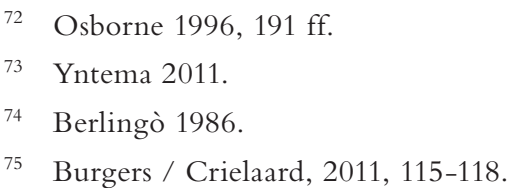

\footnotetext{
76 Osborne 1996.

77 Berlingò 1986, 1993.

78 Carter 1993; Giardino / De Siena 1999, Denti 2010.

79 Lo Porto 1964b; Neeft 1994.
} 


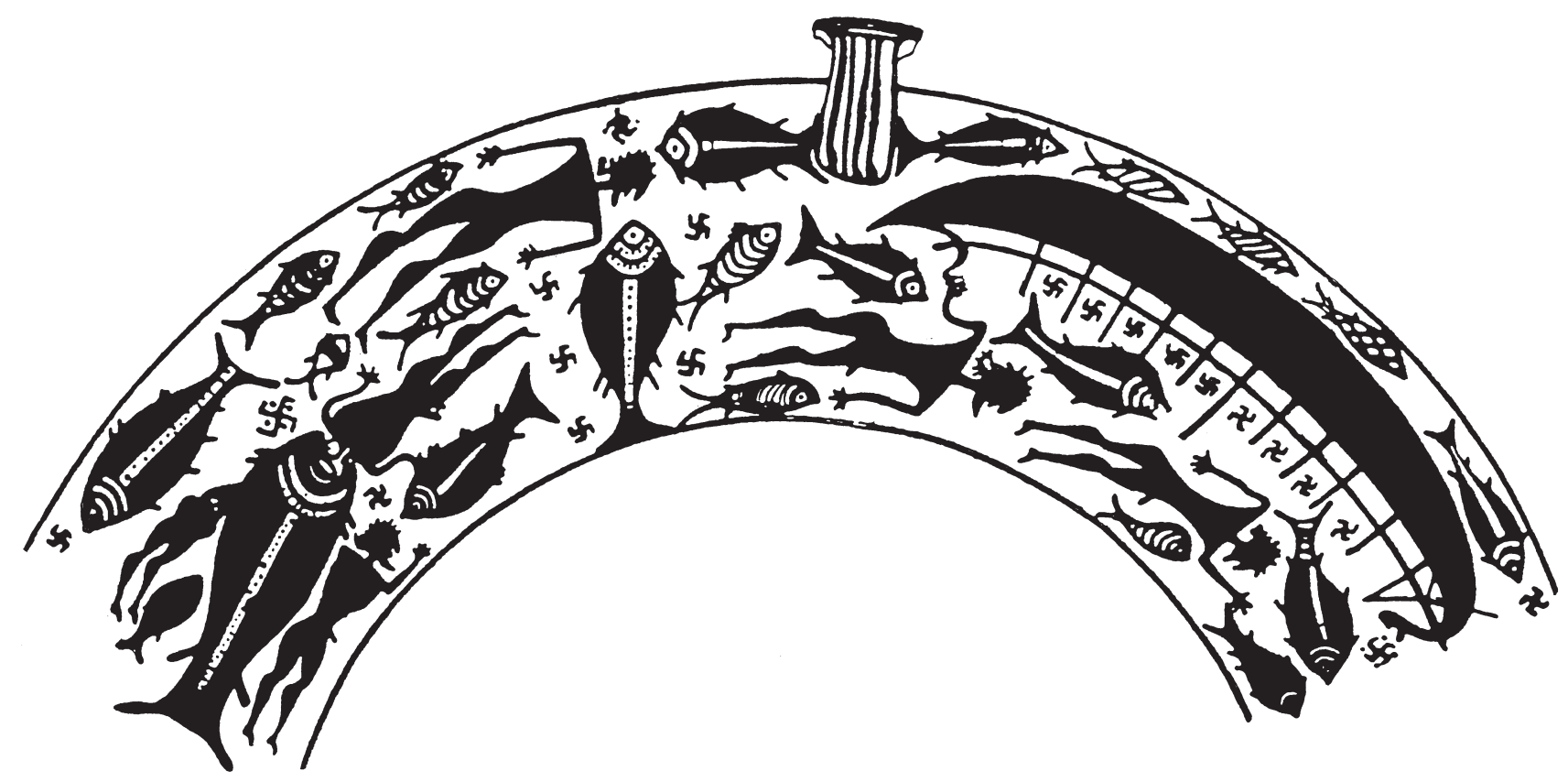

Fig. 4.9. Pithekoussai (Ischia): locally produced krater in Greek style with shipwreck scene: an Iron Age venture gone wrong, c. 725-700 BC.

this intensification may be ascribed to a steady flow of new migrants coming from various parts of Greece. As we have seen above, the necropoleis of Siris suggest that people with native roots were also among the inhabitants of the new coastal settlement. They were attracted to these new centres of craft and trade. There is good reason to assume that the rapid growth of the four coastal settlements that were to become the Greek poleis of southeast Italy was also caused by a very substantial influx of people with native roots. For reasons unknown they readily adopted the Greek material culture (and presumably also the Greek language). After about one generation they were almost undistinguishable from residents with (partly) Greek roots. By the end of the 7th or the early years of the 6th century $\mathrm{BC}$ the second or third generation of people with native roots were cornerstones in the citizen body of the emerging Greek poleis. This means that they had an evidently Greek material culture, spoke Greek, had Greek names, had a basically Greek set of norms and values and acted as Greeks were supposed to do. Moreover, they may have owned fields in the territory (chorra) of the new polis.

In the above passages much attention has been paid to exchanges with traders, the arrival of Greek migrants and the roles all these foreigners played in the societies of southeast Italy. It should, however, be noted that contacts with traders and the presence of groups of migrants were phenomena that basically affected only the coastal strip on the Ionian Sea and the Gulf of Taranto. Their importance for the south-Italic scenery and their impact on the indigenous societies during much of the 7th century should certainly not be overestimated. In the 8th and earlier 7th centuries BC Greek traders and migrants were, in fact, rather peripheral to the indigenous world of southeast Italy not only in geographical, but also in economic and social respects.

In the large inland areas of Basilicata and in central and northern Apulia the changes were considerably less drastic during the 7th century BC. While the 8th century was a period of great dynamism with a fairly massive reclamation of large patches of wild nature (the 'indigenous' colonization of the inlands and upland of southeast Italy), the 7th century shows distinct signs of stabilization and organic growth. The inland settlements retained their highly dispersed character and often expanded consider- 
ably. This observation holds especially good for the numerous new, initially small colonist settlements that had reclaimed new areas for agriculture in the interiors of Salento, the Bari district, the Tavoliere and in the uplands of Basilicata. The matching necropoleis continued to be equally dispersed, tended to become larger and continued to be made within or close to the settlement areas. ${ }^{80}$ As the settlements became more populous, their impact on the surrounding landscape became steadily larger. The small, 8th-century human 'enclaves' in the forests of southeast Italy became substantial patches of manmade landscape in the 7th century BC. In this period the impact of man on the environments of southeast Italy increased notably.

\section{4 L O NG-D IS T A C E C ONTACTS, EXCHANGE A D E C ONOMY}

In the preceding section dealing with newcomers to southern Italy the contacts with Greeks have received considerable attention. We have seen that Greeks probably raided Italian coasts. But raiding and piracy are rather inadequate ways to maintain regular contacts with the same groups over a prolonged period. Because these activities had to be widely and wildly proclaimed by Greek men of local importance as a response to the Homeric kleos ideology in order to enhance their status, they may have been partly fictional, and increasingly so as the contacts between Greeks and south-Italic groups became more regular and more intense. Peaceful, regulated forms of exchange may have occurred more often than the Homeric songs wish us to believe. ${ }^{81}$ This observation holds especially good for the post-Homeric later part of the Iron Age when Greek individuals and small groups of Greeks actually settled in southeast Italy and started to make a living in this new environment.

The sheer quantities of Aegean-Greek artefacts of the 8th and 7th centuries BC that were found in southeast Italy demonstrate that exchange between various indigenous regional groups and Greeks coming from various Aegean areas must have been very intense in these times. It should, moreover, be noted that the imported ceramics on which these observations are based are just the tip of the iceberg. These are the non-perishable goods that survived in the archaeological record. They constitute only the tracers of long distance exchange. But the possible and even probable exchange of, for instance, slaves, special foodstuff (cf. the contents of the various types of imported amphorae and pithoid jars) and precious cloth or other exotic commodities from the eastern Mediterranean escape us completely.

It is clear that people living in southeast Italy were interested in Greeks and the products made or transported by Greeks, if only because so many Greek ceramics were found there. For the indigenous south-Italic groups of the Iron Age the seafaring and migrant Greeks were an otherworld within easy reach. They offered commodities of exotic nature that (as we will see below) played an ever more important role in the dynamic and increasingly complex indigenous societies of the region.

But why were Greeks so interested in southeast Italy that they undertook dangerous ventures far beyond the threshold of their own world (fig. 4.9) and even started to live in the (formerly) strange worlds of Circe, Calypso and Polyphemus? This question is more easily asked than answered. In the first place Italy - like the Levant - was an exotic country. Bringing home booty including Oinotrian women having strange tattoos and wearing their characteristic, richly decorated Oinotrian garments (fig. 4.14) might well have had similar effects on the population of a Greek Iron Age settlement as Columbus' parading of Taíno Indians and other exotics of the West-Indies in Sevilla in 1493. In the long

${ }^{80}$ The large, 7th-century necropolis of Alianello-Cazzaiola in western Basilicata, however, was fairly condensed (cf. Bottini / Tagliente 1984; Tagliente 1985, 1986). Since no traces of habitations were discovered during the excavation of this cemetery, it was probably at some distance from the contemporary settlement.

81 Yntema 2000. 


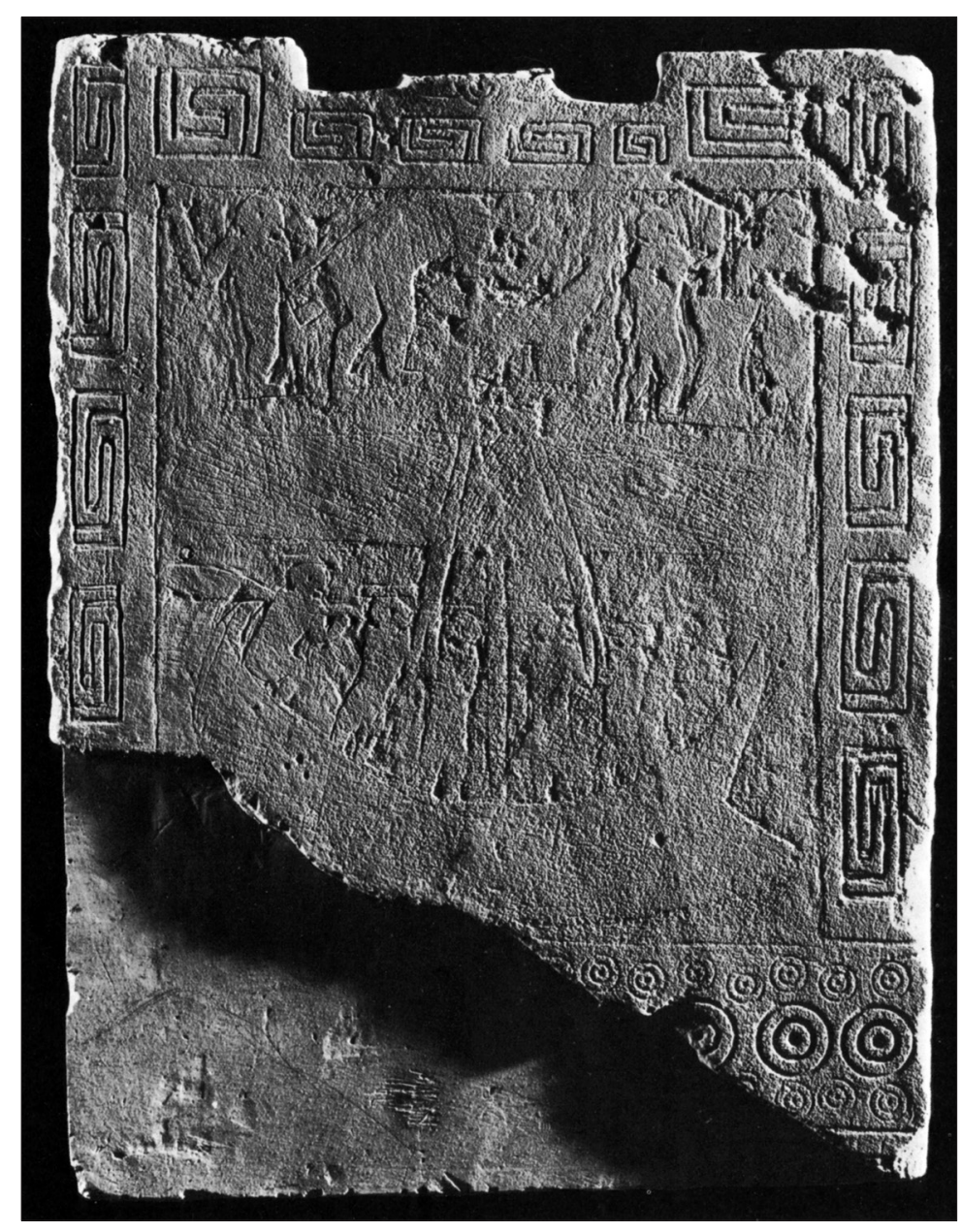

Fig. 4.10. Siponto (Tavoliere district, north-Apulia): Daunian stele with ship, late 7 th or early 6th century BC. Courtesy Ufficio Staccato Soprintendenza, Foggia.

run, however, this was certainly not Italy's main attraction, because Italy's exotic remoteness diminished rapidly when - as we have seen above - the contacts between Greece and Italy increased enormously and assumed a more structural character from the late 8th century onwards. But Italy was also a metal country. This is, of course, clearly shown by the excavations at Pithekoussai where Etruscan ore was processed in the local furnaces. Although southeast Italy itself is definitely poor in metals (with the exception of northern Calabria), there must have been an ample supply of these basic materials. The wealth of bronze and iron objects in the 9th-8th century BC burial contexts of southeast Italy demonstrates that metals were circulating here in very substantial quantities (see section 4.5).

The metals and the exotic character of Italy were certainly not the only stimuli that induced Greeks to go west. Iron Age trade and exchange was multi-faceted and rarely specialized in one single commodity. ${ }^{82}$ And southeast Italy had much more to offer. Other products that may have been desirable for Greeks were the purple dye of the murex purpurea that occurred in the seas surrounding Apulia (e.g. near Taranto and the Gargano peninsula) and Baltic amber that circulated in Adriatic areas in substantial quantities during the Iron Age. ${ }^{83}$ The colonization of inland areas and the growth of the new settlements founded there, moreover, may have led to inter-tribal warfare resulting in a steady supply of slaves. One of southeast Italy's most attractive points, however, was its geographical position. If ships from the eastern Mediterranean (Greek ships among them), for whatever reason, had to go towards the west, southeast Italy was an almost obligatory point of call. This holds especially good for the Salento peninsula that was only $70 \mathrm{~km}$ from the Balkan coast (see chapter 3.1). It is certainly not due to coincidence that by far the largest concentrations of imported early Greek pottery were found in this eastern peninsula of southeast Italy. Coastal settlements of this district, therefore, are likely to have provided Greek ships with water, food and shelter and received commodities from their cargo in return. Usually, however, conducting trade and providing food, water and shelter was all part of the

82 Mele 1979

83 For the murex purpurea, see Delano Smith 1979; for Iron Age amber in Italy, see Negroni Cataccio 1989; a wealth of amber objects from Iron Age Basilicata has travelled widely over the past six years: e.g. exhibition Magie d'ambra. Amuleti en gioielli della Basilicata antica (Potenza 2005) and Zauber in Bernstein. Schmuck und Amulette aus der Basilikata (Zürich, Cologne 2011). 
same interaction between Greeks and non-Greeks. Guest-friendship and gift exchange may well have been the mechanisms by which the commodities changed hands and services were rendered.

The network spanning the Ionian Sea with eastern Sicily, the coastal area of the Gulf of Taranto and north-western Greece as constituent parts, was only one of a series of interrelated trade and exchange networks active in and around southeast Italy in the Iron Age. From the above passages can be derived that it was linked to other maritime exchange networks such as the network spanning the southern Aegean with extensions to the Levant, the network in the central and southern Tyrrhenean linking the coastal settlements of southern Etruria, Sardinia, Pithekoussai in the Bay of Naples and Pontecagnano in southern Campania, and the Adriatic networks where Greeks rarely ventured before the 6th century BC.

It is important to observe that the maritime network that connected the districts on the Ionian Sea was also closely connected to south-Italian regional exchange networks using land routes. These can be reconstructed on the basis of 8th- and early 7th-century ceramics of South-Italian Geometric type of which three regional variants travelled far beyond the district in which they were produced. From these data it becomes clear that the rivers were important routes of communication. Pottery made in western Basilicata is found in the Paestum area of southern Campania: from their production area near the coast of the Ionian Sea the matt-painted vessels travelled upstream along the rivers Agri and Sinni and climbed the watershed to end up in Campania and south-Etruria. The matt-painted wares from the north-Apulian Tavoliere district crossed the Apennines and reached the plain around Naples, while the finely made, 7th - to early 6th-century pottery of the adjoining Ofanto district was distributed in both the north-Apulian Tavoliere and the basins of the Bradano and Basento rivers in eastern Basilicata ${ }^{84}$ It is, therefore, not particularly remarkable that settlements with a mixed Greek-native population (e.g. Siris, Metapontion and perhaps Sybaris) came into being at river mouths and that the originally indigenous site of L'Incoronata in an identical geographical position harboured a substantial group of Greeks. Each of these settlements was born and thrived at the spot where two exchange systems met. Therefore, they were crucial pivots between a maritime network and an overland network; they were ideally placed to act as go betweens linking Greek trade systems with indigenous exchange networks. From the Greek point of view they effectively tapped existing indigenous trade routes and exchange networks, for the indigenous world they were doors giving access to maritime exchange circuits that spanned large parts of the Mediterranean and brought within easy reach commodities stemming predominantly from various eastern Mediterranean areas (Greece among them).

The creation of maritime trade networks was not the prerogative of the Greeks. If non-Greek ships were active in the Gulf of Taranto in the 8th or 7th century BC, their role escapes us completely. ${ }^{85}$ But the Adriatic was definitely the domain of non-Greek seafaring in the Iron Age. Here Greeks started to venture only in the course of the 6th century. Seaworthy ships of evidently non-Greek type are depicted on grave markers from sites on the central and northern Adriatic (fig. 4.10), ${ }^{86}$ but it is espe-

84 For south-Italian matt-painted wares from the AgriSinni area in Campania and south-Etruria, see Yntema 1990, 118; for north-Apulian wares in Campania, see Yntema 1990, 231 and 293; for matt-painted wares from the Ofanto district in large parts of southeast Italy, see Yntema 1990, 231 and 242.

85 Early 7th-century matt-painted pottery characteristic of the Salento peninsula has been found at some non-Salento sites around the Ionian Sea (L'Incoronata, Sybaris, Francavilla Marittima, Megara Hyblaea). Such pots could have been transported by both 'native' and Greek ships.

86 Ships are shown on the so-called 'Daunian stelai' from the coastal Tavoliere settlement of Siponto-Cupola (Nava 1981, stelai 616, 737 and 775); the representations can be dated to approximately the late 7 th and early 6th centuries BC. The best-known representation of an 'Adriatic' ship is found on one of the stelai from Novilara (Marche region) of the late 6th century BC. 

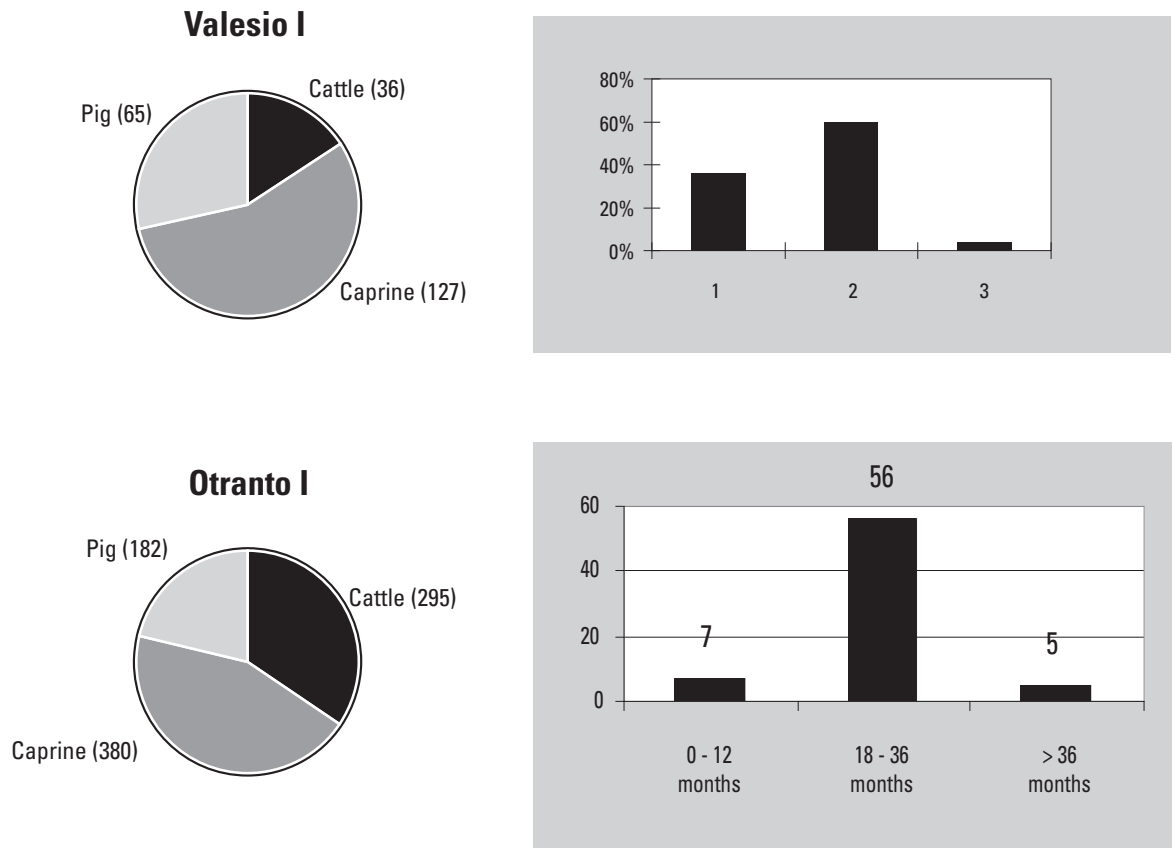

Francavilla

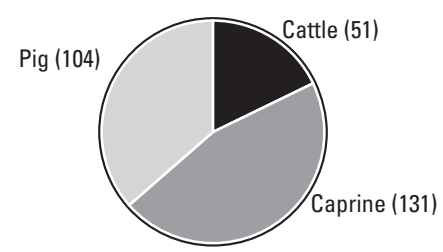

L'Incoronata

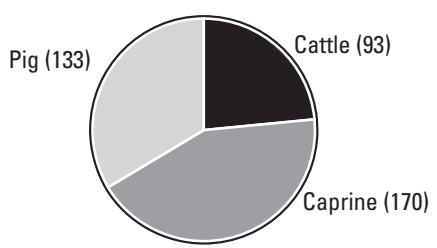

Fig. 4.11. Iron Age bone samples from Valesio (Brindisi district), Otranto (southern Salento), L'Incoronata di Metaponto (coastal area of Basilicata) and Francavilla Marittima (northern Calabria) and culling ages of caprines at Valesio and Otranto; after Veenman 2002.

cially the matt-painted pottery made in the Ofanto district that reveals these networks of the 7th and 6th centuries BC. These wares are found in fairly considerable quantities in the Picenum district near Ancona, in the coastal districts of present-day Croatia (especially Istria and Dalmatia) and in Slovenia (fig. 4.17). Finely decorated, handmade pots, mainly stemming from the settlement of Canosa, ended up in the burials of chieftains of Picenum and in the tumuli of the local elites of Istria, Dalmatia and Slovenia. ${ }^{87}$ This Adriatic network can be shown to have existed from the late 9th century till after the middle of the 6 th century BC. ${ }^{88}$ Among the products that were exchanged there may have been Baltic amber that had reached the Caput Adriae, salt and murex dye from northern Apulia and/or fine

87 See Yntema 1990, 231 and 242. In the Picenum district the Ofanto matt-painted wares from Canosa were found at, for instance, Novilara, Ancona, Numana and Cupramarittima. In Dalmatia the bulk of Ofanto wares published hitherto stems from the Zadar/Nin area; in Istria the sites of Nesactium and Pula seem to have received the lion's share of these wares, whilst Ofanto matt-painted also turned up in Slovenian Hallstatt burials at Vače, Stična, Magdalenska Gora, Podzemelj and Novo Mesto.

88 One of the earliest matt-painted pots found in Croatia is a conical-necked jar from Hvar (see Petrić 1993, pls. XCVII-XCIX) dating to the 2nd half of the 9th or the early years of the 8 th century BC. 
cloth dyed in it. Since the Canosan matt-painted wares reached the eastern Hallstatt province around present-day Ljubeljana, one of the more vital commodities that travelled within this trade system may have been the metals of Slovenia. For southeast Italy and perhaps for Greek traders based in southeast Italy, these districts could be an alternative source to Etruria for these basic materials. Metals from the eastern Hallstatt province may well have reached Metapontion or Otranto where they could enter the Ionian Sea exchange network and be shipped to distant areas.

In the Iron Age southeast Italy was involved in, or closely connected with a series of both maritime and overland trade networks in which various types of commodities were exchanged on a regular and intensive basis. The most vital spots were those where two networks or routes met. The settlements that developed at these nodal points were often very successful and evolved rapidly into flourishing ports of trade. Siris, starting in the first quarter of the 7th century, was such a settlement. It connected the network comprising the districts around the Ionian Sea with trade routes of western Basilicata that were linked with the plain of southern Campania. ${ }^{89}$ Metapontion (from c. 630/620 onward) and the earlier dispersed settlements with mixed population preceding this polis, ${ }^{90}$ were comparable hotspots. They linked the same maritime network to overland routes leading to the uplands of Basilicata and towards northern Apulia. In the northern districts of Apulia the settlement of Canosa was probably a crucial link between the overland route coming from Metapontion and the 'native' maritime network active in the Adriatic, whilst Otranto could have been a nodal point between the latter and the maritime network spanning the Ionian Sea.

The finely painted pots that allowed us to trace these exchange activities are only a fraction of the commodities that travelled in and around southeast Italy during the Iron Age. They suggest both a great diversity and a great intensity of interregional and intercultural contacts. The intensive character of the trade networks and frequency of these long distance contacts suggest that new ideas on quite a number of topics could travel fast and be diffused over large distances during the Iron Age. In the present state of research, it seems that these did not exert a major influence on settlements and settlement patterns discussed in section 4.2. New ideas from both originally external sources (the Greek world) and basically internal sources (other 'indigenous' districts) can be traced in both craft and funerary customs in southeast Italy. These will come up for discussion in the following sections of this chapter on the Iron Age.

In this section trade and exchange have received ample attention. It is clear that the impact of these activities on the societies of southeast Italy was very substantial indeed. Objects coming from distant regions may have become vital for the display of status and wealth and crucial in the sealing of elite marriages, guest-friendships and other types of human bonds. In strictly economic terms, however, these activities were of only modest importance. In pre-industrial societies agriculture and stock raising are invariably the basis of the economy. Iron Age southeast Italy is unlikely to have been an exception to this rule. In this field southeast Italy still held another attractive feature for the Aegean Greeks: it was a very fertile and relatively thinly populated region which the Greek lyric poet Archilochos of Paros greatly preferred to the nearby, stony island of Thasos. ${ }^{91}$

The archaeological evidence from southeast Italy concerning Iron Age agriculture is extremely thin. ${ }^{92}$. Pollen do not preserve well because of the nature of the soils and macro-remains have not

89 Here the Greek polis of Posidonia/Paestum came into being in the late 7 th century BC.

90 The dispersed settlement plots preceding the urban phase at Metapontion are Metaponto-Andrisani and Metaponto-Lazzazzera (both 2nd-3rd quarter of the 7th century)

91 Archilochos, apud Athenaeus XII, $523 \mathrm{~d}$.

92 Lentjes 2013. Evidence predominantly from the Metaponto area; see Carter 1987 and 2006. 


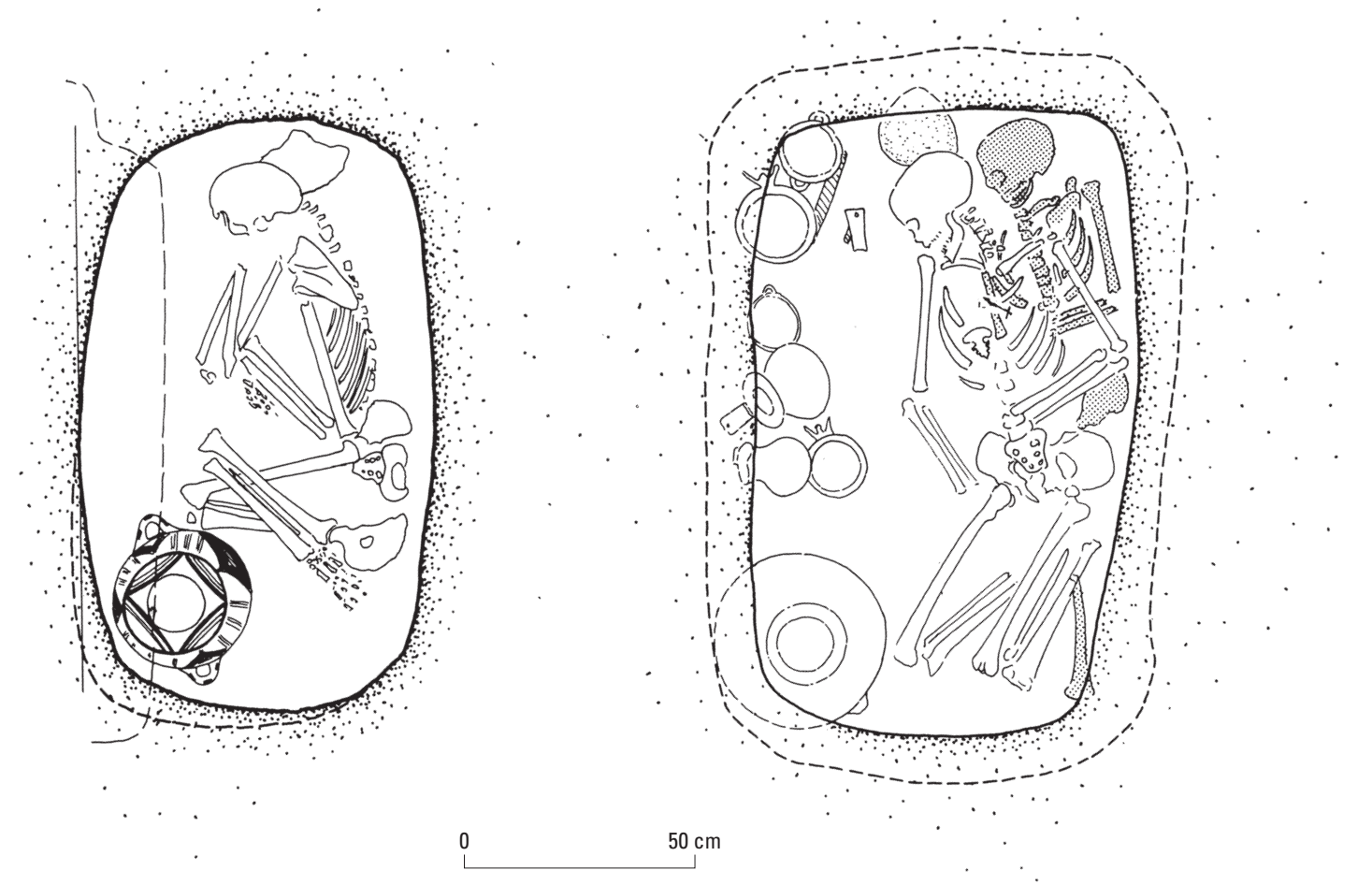

Fig. 4.12. Burial forms of pre-Roman southeast Italy: (a) pit grave with single deposition; (b) pit grave with two/three depositions (unusual); both from Ordona, adapted from Iker 1984.

always been systematically collected. In the contexts coming from the 7th-century phase of the site of L'Amastuola (excavations 2003-2008) barley (Hordeum vulgare), emmer wheat (Triticum dicoccum), bitter vetch (Vicia ervilia) and beans are relatively common. ${ }^{93}$ Land evaluation shows that many parts of southeast Italy have soils that - by Iron Age standards - are admirably suited for the cultivation of cereals, various types of vegetables, olives and vines. ${ }^{94}$ Since these crops were also cultivated during the Late Bronze Age, it is plausible to assume that they continued to be present in the Iron Age. There has been a tendency to see the introduction of olive trees and vines as benefits of the Greek colonization of Italy in the 8th and 7th centuries BC. However, recent research reveals that this view is unfounded. ${ }^{95}$ It is likely to be the product of the Graeco-centric approach in Classical archaeology.

The information about the animal husbandry of the Iron Age is somewhat more solid. ${ }^{96}$ Over the past twenty years various bone samples have been analysed. These stem predominantly from the coastal area of Basilicata and the Salento peninsula. In these samples the bones of horses (Equus caballus) are uncommon. Horse gear, moreover, is rarely found in the graves of these districts. ${ }^{97}$ Since the use of horses is repeatedly shown in figurative representations (fig. 4.20) and is widely attested in elite contexts in other parts of Italy, these animals were undoubtedly present in southeast Italy. Apparently, however, horses were not consumed.

93 Lentjes 2013 (forthcoming).

$94 \quad$ Van Joolen 2003.

95 Lentjes 2013 (forthcoming).

96 Veenman 2012, 79-82.

97 In the plain of northern Apulia horse bridles are found indeed during the Iron Age. Iconographical data from the so-called Daunian stelai (mostly from the site of Siponto-Cupola) indicate that horses played an important role in the north-Apulian societies of the 7th and 6th centuries BC (Nava 1981). 
In the Iron Age bone samples of the region under discussion there is invariably a dominance of sheep/goat (Ovis/Capra). Currently these account for c. 45 to 55 percent of the bones in many samples. ${ }^{98}$ The mortality data indicate that most animals of this species were killed in or after their third year (fig. 4.11). This suggests that they were mainly kept for their wool and their milk (cheese). Cattle (Bos taurus) usually hold the second place among the animal husbandry of the Iron Age settlements and account mostly for 20 to 25 percent of the bones in the sample of southeast Italy. They were usually killed after their fourth year and some of them even reached the venerable age of eight years. This means that they were primarily used for traction and were consumed when they had served their main purpose. The percentage of these animals, however, is much higher than is strictly necessary for economic purposes. ${ }^{99}$ This 'over-representation' in the bone samples indicates that cattle had not exclusively a purely economic function in the period under discussion. Presumably, each Iron Age farmer had his own yoke of plough oxen, whilst the more opulent families of the settlement may have had small herds of these probably prestigious animals. The percentage of pigs (Sus domesticus) varies considerably and was basically site-bound during the Iron Age. Generally speaking, the animal was only slightly less numerous than cattle in the Iron Age bone samples (between 17\% and $36 \%$ ), but at some of the Iron Age sites they held the second place behind sheep/goat. ${ }^{100}$ The Iron Age pigs were kept for their meat. The mortality data indicate that they were almost invariably culled during or at the end of their second year. Hunting supplied additional food. It is especially red deer (Cervus elaphus) that is relatively well represented in the Iron Age bone samples of southeast Italy (often 5\% to 6\%). Their ample presence in Iron-Age bone samples from all over southeast Italy indicates that substantial parts of this area were densely wooded.

The data presented above suggest that the Iron Age populations collected and cultivated crops and vegetables. Cereals and pulses were undoubtedly among them. We simply do not know whether they had olive groves and vineyards. ${ }^{101}$ But it is plausible to assume the presence of these crops in the Iron Age landscape, because there is ample evidence for their presence in both the preceding phases of the Bronze Age and the subsequent Archaic-Classical period. Sheep and goats were among the pillars of the Iron Age economy of southeast Italy. The sheep supplied the wool that was worked by the women of the settlements: loom weights, and spindle whorls are frequently encountered both in the graves of Iron Age ladies and in the huts of the settlements. Both sheep and goats were important sources of proteins (milk, cheese, meat) and their hides (especially those of the goats) could be used for bags and clothing. The flocks of these animals must have grazed in a variety of environments. In summer they could be found in the summer pastures of the southern Apennines, in winter they grazed the fallow plots near the settlements, while lagoonal areas on the coast, marshy river valleys and the ample stretches of macchia vegetation could be used in various seasons.

Cattle were needed for traction. They also supplied meat and hides and were probably important in the display of status: the numbers of cows and oxen owned by a social group (e.g. family, clan) probably closely mirrored the group's status. In Iron Age southeast Italy cattle were equivalent to wealth. Their prime economic function (traction) required them to stay relatively close to the settlement. Since they are exacting in their demand for food, they may have browsed mainly in the lush vegetation lining the streams and rivers which were never far from the habitation areas. Pigs stood for proteins,

98 The percentages are all based on counts of the number of fragments of the household animals only. Red deer, for instance, which sometimes makes up $5 \%$ of the total bone samples of the Iron Age, is excluded in this count.

99 The economic rationalization of Roman times shows that transport and ploughing could be done effectively with $5-10 \%$ cattle (Veenman 2002).

100 Notably at L'Incoronata near Metaponto and Francavilla Marittima in northern Calabria (Veenman 2002, 79).

101 The olive stones and grape pips found in Iron Age contexts may belong to cultivated as well as wild species. 


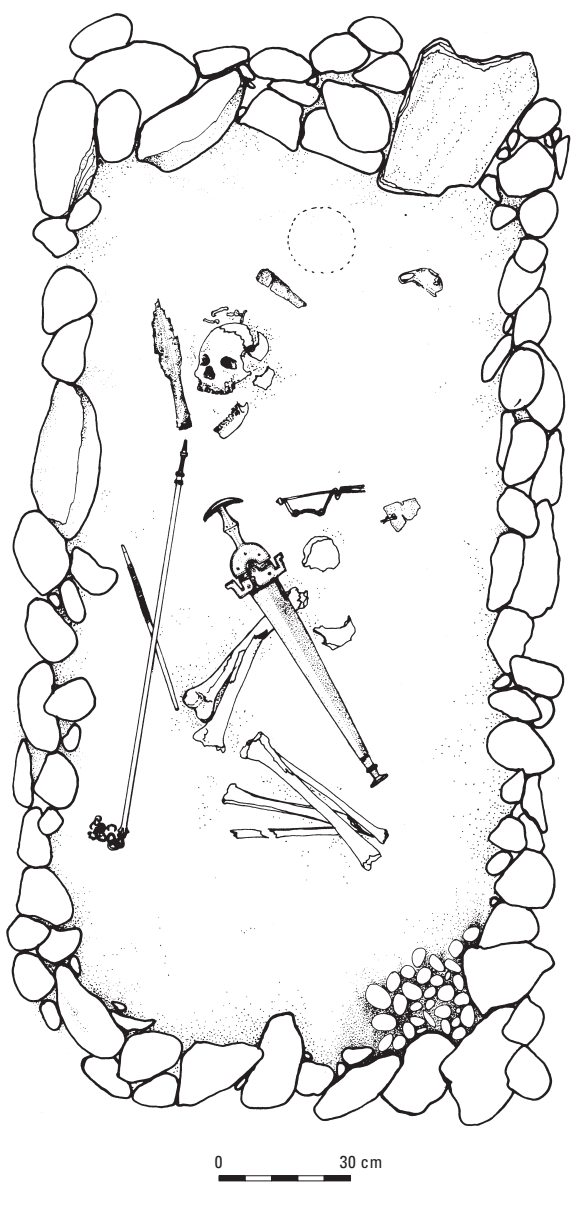

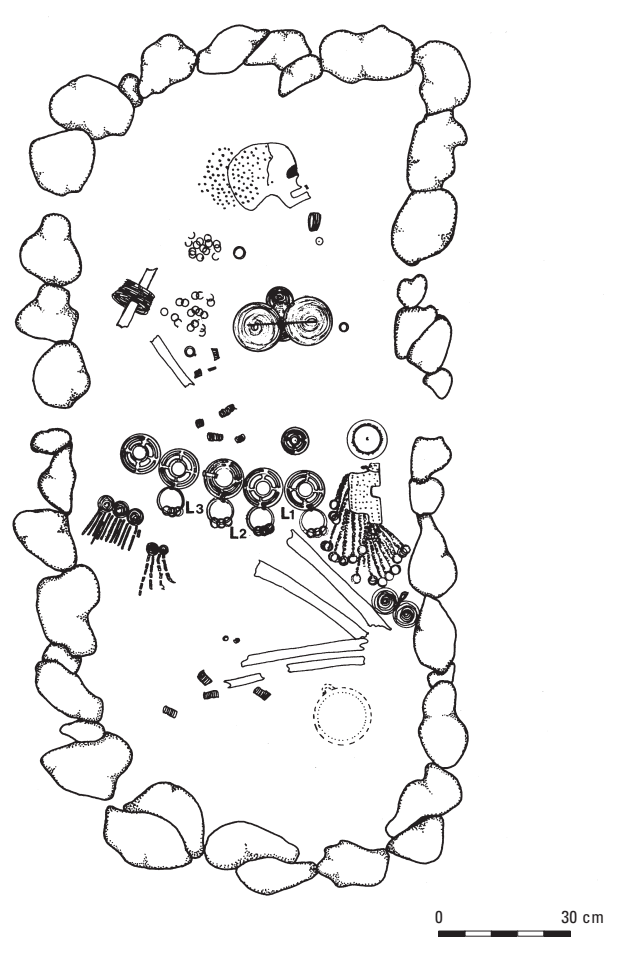

Fig. 4.13. L'Incoronata (Matera district, southeast Basilicata): (a) male burial 454 with sword and spearhead (8th century BC); (b) female burial 468 with a wealth of bronze ornaments (8th century BC); after Chiartano 1994 and 1996.

hides (pigskin) and bristles. Some of these animals may have been kept within the settlement area, but mostly the herds of swine will have roamed the woods feeding on acorns and whatever else the woods had to offer.$^{102}$

\subsection{B UR I A L S, S O C I A L S T R A T I F I C A T I O N A N D R E L I G I O N}

In the Bronze Age both inhumation and cremation were practiced in southeast Italy (see chapter 2). From the beginnings of the Iron Age onward the deceased were almost invariably inhumed. ${ }^{103}$ This practice continued to be the dominant funerary custom in southeast Italy to within the 1st century BC. The details of the inhumation practices, however, could vary considerably. These depended on the factors of time, place, status and gender: there were changes in burial practices in the course of time, there were regional and even local differences within southeast Italy and the care bestowed upon the tomb could vary according to the status. The objects deposited in the grave were, of course, often related to the sex of the deceased. But the general lines in the burial customs of southeast Italy during a large part of the first millennium BC were simple: in order to bury an adult or a child a more or less

102 Veenman 2002, 141.

103 The Salento peninsula may have been an exception to this rule. Although this district is quite thoroughly investigated, no Iron Age burials have been found here. The earliest formal burials here date to the very end of the 7 th or the early years of the 6th century 

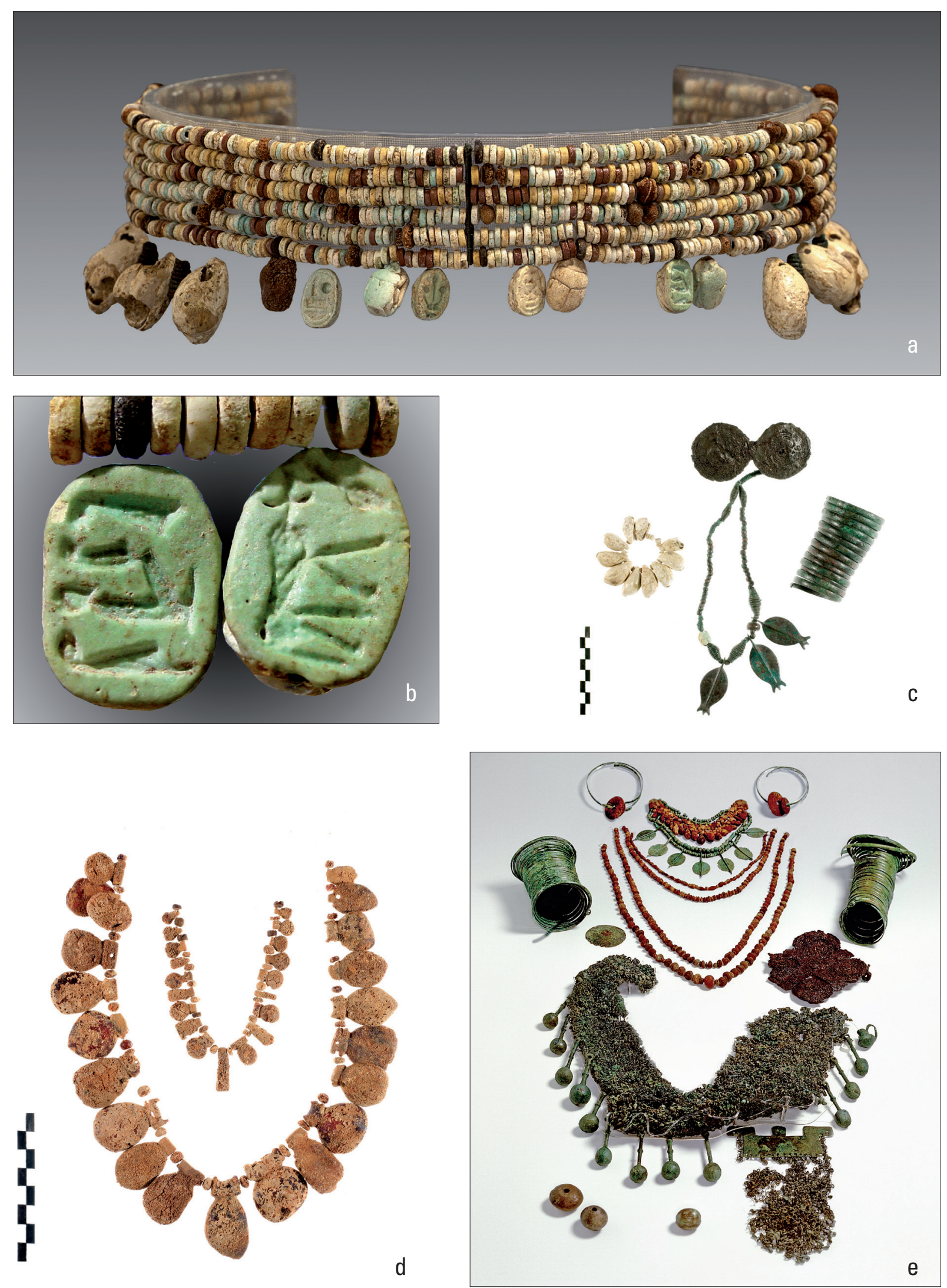

Fig. 4.14. Western Basilicata burial gifts of important ladies (7th century BC): a-d Chiaromonte-Sotto la Croce tomb 129 (diadem with beads: amber, ivory, glass, and scarabs; e Alianello tomb 315 (courtesy Soprintendenza Basilicata). 

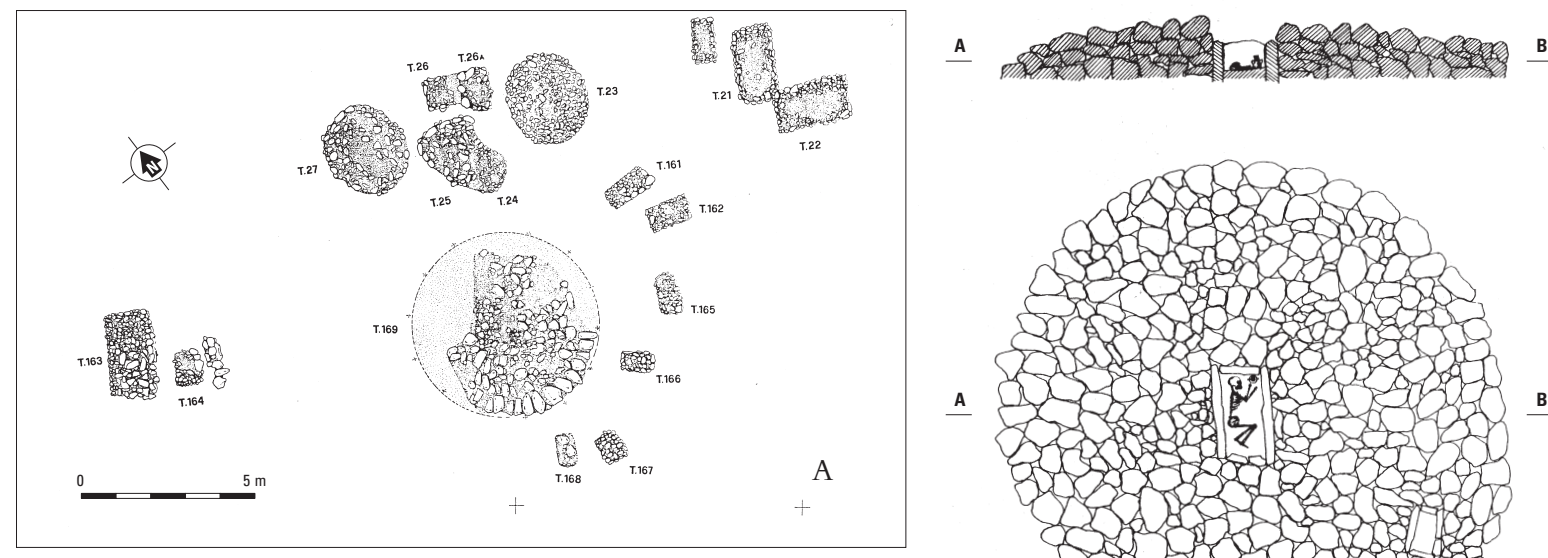

A
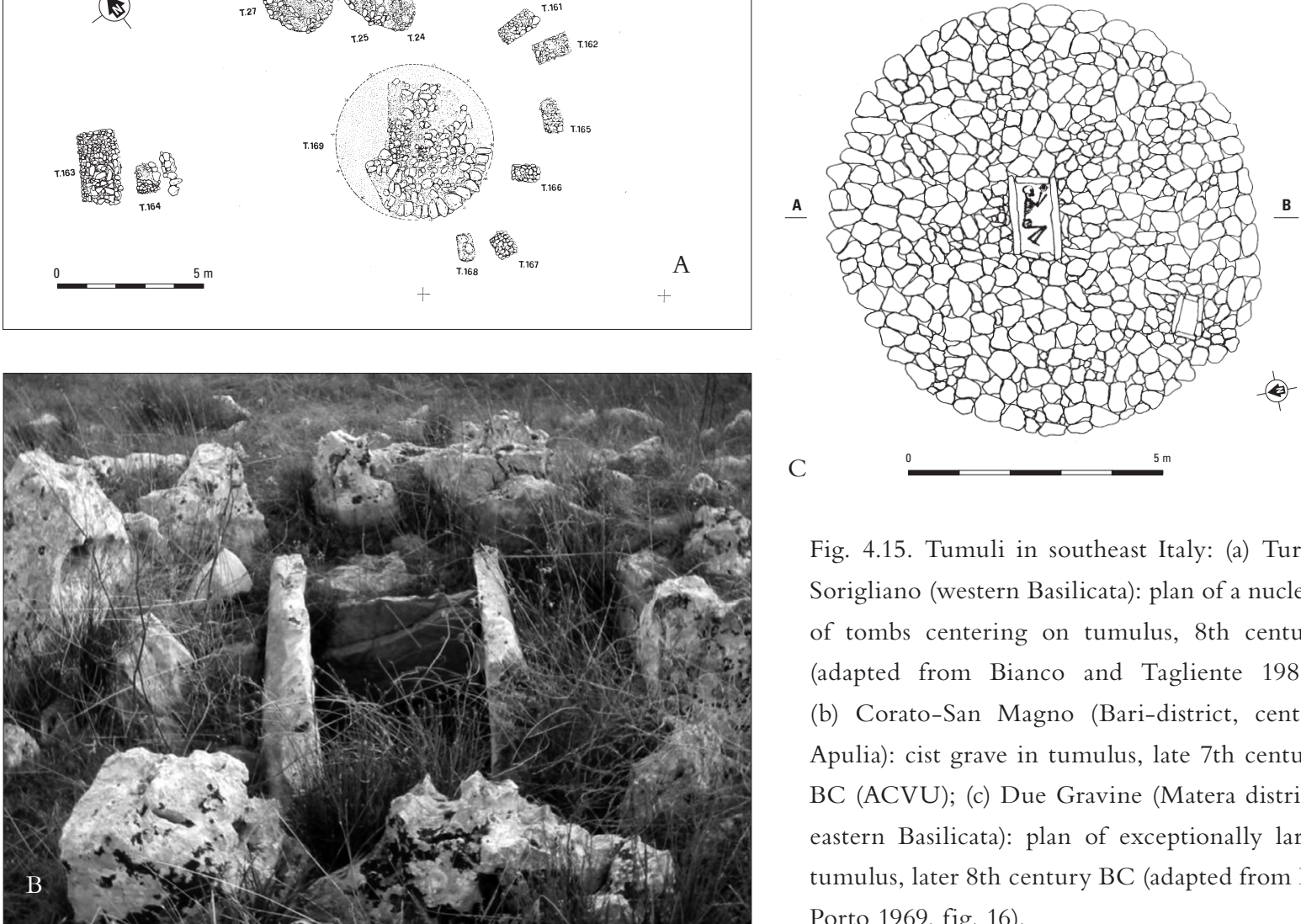

C

Fig. 4.15. Tumuli in southeast Italy: (a) TursiSorigliano (western Basilicata): plan of a nucleus of tombs centering on tumulus, 8th century (adapted from Bianco and Tagliente 1985); (b) Corato-San Magno (Bari-district, central Apulia): cist grave in tumulus, late 7 th century BC (ACVU); (c) Due Gravine (Matera district, eastern Basilicata): plan of exceptionally large tumulus, later 8th century BC (adapted from Lo Porto 1969, fig. 16).

rectangular trench (Italian: fossa) was dug into the ground or cut into the rock in the family cemetery of the settlement. The deceased was almost invariably laid on his or her side in a contracted position (legs drawn up). ${ }^{104}$ In the territories of the Greek city states, in western Basilicata and adjacent parts of Calabria and Campania, however, the deceased was buried on his/her back. ${ }^{105}$ These fossa graves usually contain one single individual (fig. 4.12a). In a few cases more people were buried in the same tomb. This practice occurred regularly in northern Apulia (fig. 4.12b). ${ }^{106}$ Babies (and perhaps miscarriages and stillborns), however, were usually buried in a completely different way. They were deposited in a large ceramic container vessel. This was mostly an impasto storage jar. ${ }^{107}$ The remains of the very young person were interred near the dwelling - sometimes even underneath the hut or house floor - in which his closest relatives continued to live. ${ }^{108}$

BC. A few cremations in the coastal area dating to the late 8 th/early 7 th century are often interpreted as the graves of Greek colonists or traders.

104 Italian: posizione rannicchiata

105 Italian: posizione supina

106 The practice of more than one deposition in the same burial pit is also encountered in the Melfi district in northern Basilicata that shared several features with the adjoining north-Apulian district during the 6th and early 5 th century BC.

107 Italian: tomba ad enchytrismos

108 This type of infant burials seems to disappear between the middle of the 5 th and the middle of the 4 th century BC. 

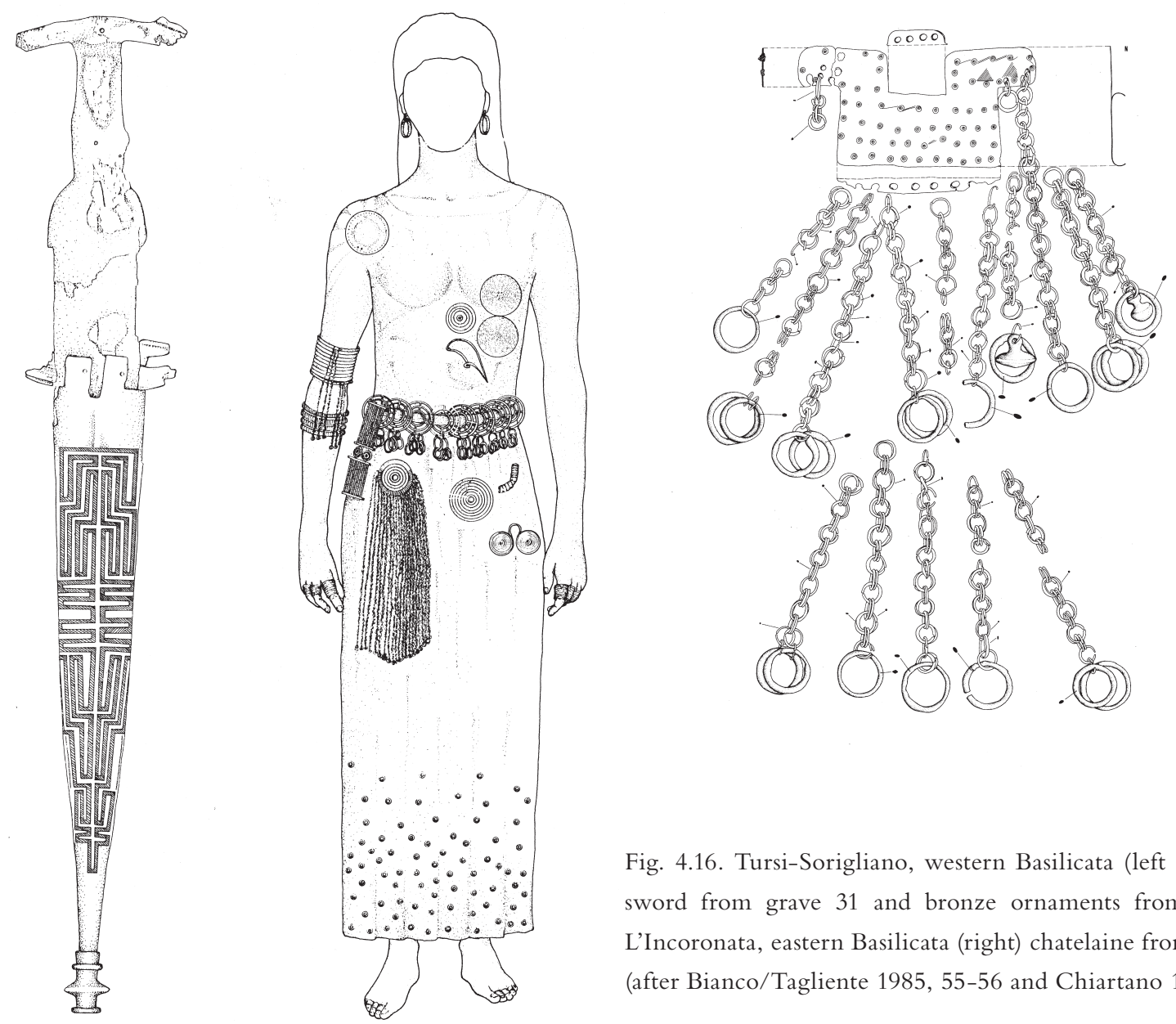

Fig. 4.16. Tursi-Sorigliano, western Basilicata (left and centre): sword from grave 31 and bronze ornaments from grave 28; L'Incoronata, eastern Basilicata (right) chatelaine from tomb 468 (after Bianco/Tagliente 1985, 55-56 and Chiartano 1996).

The Iron Age tombs did not diverge much from this general 1st millennium BC scheme. In this period the rectangular burial trench could be lined with river stones or limestone slabs. Especially in the 8th century BC, several tombs are likely to have been covered by a small tumulus or a heap of stones serving as a grave marker. ${ }^{109}$ There was substantial variation in the types of objects that accompanied the deceased. For the 9th and 8th centuries the best evidence comes from the burial grounds of the site of L'Incoronata-San Teodoro, slightly west of Metapontion. These have been systematically explored resulting in a generous and probably fairly representative sample of well-published graves. ${ }^{110}$ The quantity and quality of the grave goods at this site could vary considerably. The types of objects deposited in the tomb were mostly gender-related. A considerable portion of the male burials contained lance heads. Only very few of these (invariably 'rich' burials) had both a sword and a lance head (fig. 4.13a) and some male burials had no weapons at all. The sword is a recurring item in well furnished male tombs in other districts. Obviously this object was indicative of a man of high status in southeast Italy. The contemporary female burials are characterized by the presence of spindle whorls, loom weights

109 This custom continued to live on in northern Apulia to well within the 6th century BC (see Striccioli 1989 and 1990: tumuli at Corato San Magno, Bari area).

110 For the burials of San Teodoro-L'Incoronata, see Chiartano 1977, 1994 and 1996. There is also a good sample of 9th - and 8th-century graves from the necropoleis of Sala Consilina (Kilian 1964, 1970). This site is in the border area between southern Campania and southeast Italy. Its 9th- and 8th-century burials grounds differ in several respects from those of southeast Italy (e.g. both inhumation and cremation) and are therefore, not discussed here. By the 7th century BC the burials of Sala Consilina answered to all the characteristics of southeast Italy. 


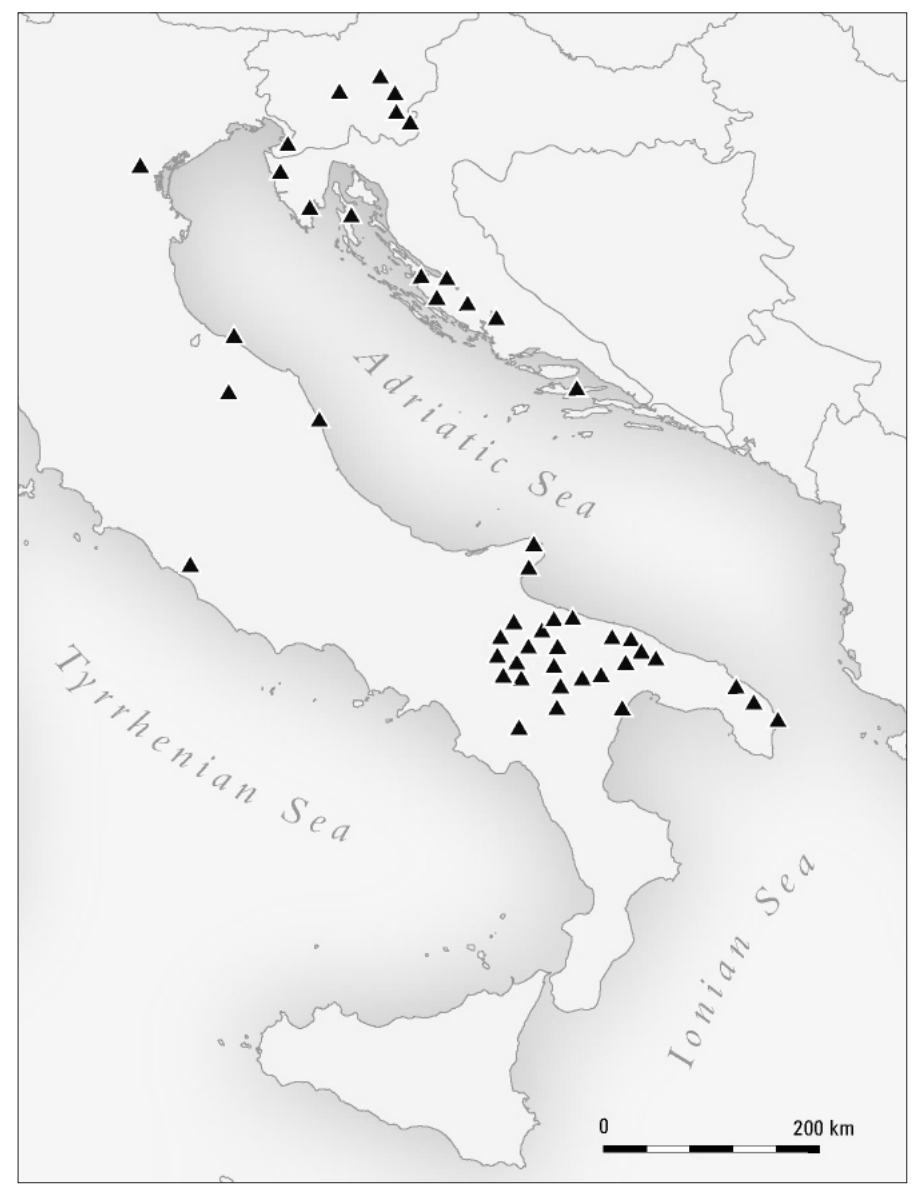

Fig. 4.17. Distribution of matt-painted wares made at Canosa, north-Apulia during the later 7th and early 6th centuries BC.

and various types of bronze ornaments. The latter could be applied to clothes or appended to a belt (fig. 4.13b).

The L'Incoronata graves of the 9th and 8th centuries often contained considerable quantities of metal objects. The same graves contained only a limited number of pots (usually one to three specimens). These belonged either to the matt-painted, South-Italian Geometric class or the burnished impasto wares. The less complete evidence from other sites of southeast Italy, suggests that this site was not exceptional in its burial customs. Very similar graves have been excavated at sites in other parts of Basilicata and central and northern Apulia. ${ }^{111}$

For the 7th century $\mathrm{BC}$ we have no large, well-published burial plots. The best information comes from the peripheral site of Sala Consilina on the northwestern fringes of ancient Lucania. ${ }^{112}$ Here a rather sudden shift in the burial customs can be observed during the first half of the 7th century. In these years the now lavishly decorated, predominantly bichromatic matt-painted pottery almost completely replaced the metals. Burnished impasto wares, moreover, vanished from the graves. The funerary evidence from sites that are more centrally situated in the districts of southeast Italy, suggests that the same developments took place here. Moreover, from about the middle of the 7th century onward metal objects are almost exclusively found in the graves of the local elites (fig. 4.14).

Section 4.2 has demonstrated that the 8th century BC is characterized by a substantial population growth and the emergence of a distinct settlement hierarchy in southeast Italy. From sections 4.3 and 4.4 it has become clear that the increasing intensity of various forms of exchange with foreigners (Greeks, 'Hallstattians', other indigenous groups of Italy) and the presence of 7th-century migrants in the coastal areas also contributed in a considerable way to increased societal complexity in southeast Italy. It is, therefore, hardly surprising that from the 8th century onward persons can be traced who were men and women of local importance and constituted a new and conspicuous elite of the Italic groups. The evidence on this subject comes exclusively from burials.

111 For instance, Lo Porto 1969 (the area north of Metapontion) and Iker 1984 (Ordona).

112 La Genière 1968. Impressive 7th-century burials plots at Chiaromonte-Sotto La Croce and Alianello-
Cazzaiola (western Basilicata) have not yet been published (cf. Bianco / Tagliente 1985; exhibition Magie d'ambra. Amleti e gioielli della Basilicata antica, Potenza 2005, = Zauber in Bernstein, Zürich/Cologne 2011). 


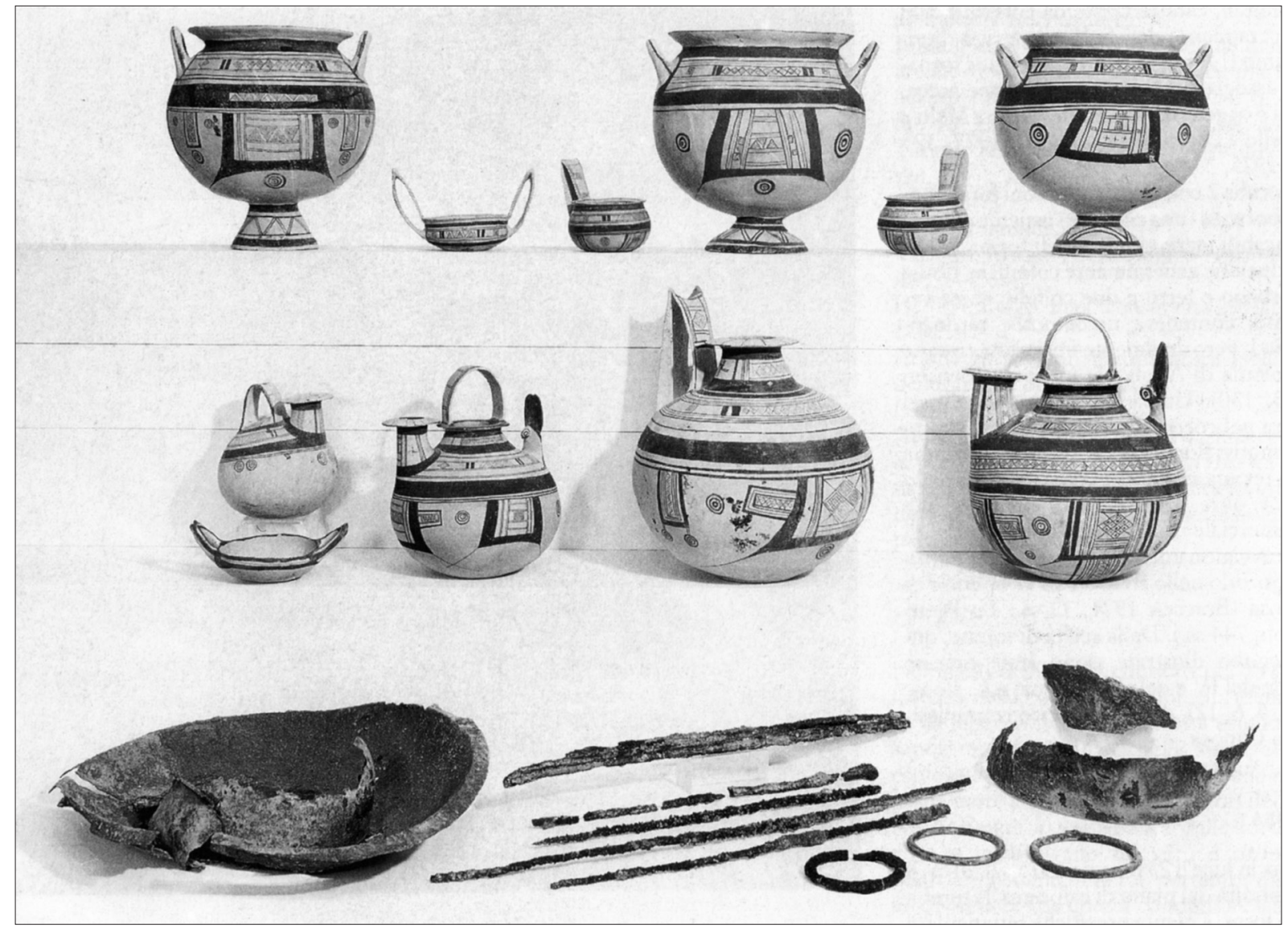

Fig. 4.18. Canosa-Toppicelli (Ofanto district, north-Apulia): tomb of local chieftain (late 7th century BC); courtesy Soprintendenza Taranto.

Among the graves dating to the 8th century BC, a few stand out because of their special contents and the care bestowed upon the burial. Most of these special tombs are tumuli (fig. 4.15). According to the Iron Age custom, these were erected in or near the settlement area, in or near grave plots of the 9th and earlier 8th centuries BC. The Iron Age tumuli are decidedly smaller than the enormous tumuli of the Bronze Age. They usually had a diameter between c. $3.00 \mathrm{~m}$ and $6.00 \mathrm{~m}$ (in exceptional cases up to $9.00 \mathrm{~m}$; fig. $4.15 \mathrm{c}$ ). Although there is some similarity in the type and structure between the burials of these two periods, the places occupied by the Iron Age tumuli in the landscape differed notably from those of the large Bronze Age tumuli. The latter which were clearly visible in the Iron Age landscapes of southeast Italy, were at a considerable distance from the Bronze and Iron Age settlements. The Iron Age tumuli, however, were close to or possibly even within the habitation areas.

In the 8th and 7th centuries BC the burial mound consisted of cobblestones or large pieces of limestone. It invariably covered rectangular pit or cist grave. In the earliest specimens of these graves high rank is expressed by a wealth of metal objects. A good example of a male elite grave is the tumulus tomb no. 31 of the Valle Sorigliano necropolis near the important site of Santa Maria d'Anglona in Basilicata. It can be dated to the middle of the 8th century. A finely decorated sword (fig. 4.16a), a dagger, two lance heads and axes characterize the deceased as a warrior. His female companion in the adjoining tumulus no. 28 had a dazzling series of bronze ornaments; a splendid disc of gold (oriental import) was found on her shoulder (fig. 4.16b). Both graves belonged to a small group of burials within a somewhat larger burial plot (fig. 4.15a). 
The Valle Sorigliano burials were not unique. Many more tumuli of this type must have existed. Since they were conspicuous elements in the landscape, only a limited quantity of them survived in the archaeological record. ${ }^{113}$ They were, moreover, not confined to the coastal strip of southeast Italy, i.e. the area that was most strongly affected by external factors. Very similar burials having a high visibility in the Iron Age landscape and containing a few pots and a wealth of metal objects, were also found in the Tavoliere district in northern Apulia, some $250 \mathrm{~km}$ from the Gulf of Taranto. ${ }^{114}$ Therefore, the appearance of impressive tombs and the emergence of local elites in Basilicata and Apulia cannot be linked with the appearance of the Greeks on the shores of southeast Italy.

The emergence of these indigenous elites indicates that social stratification became more complex in the 8th century BC societies of southeast Italy. This is, for instance, apparent in the well-published reports on the Iron Age burial grounds of the coastal site of L'Incoronata-San Teodoro mentioned above. ${ }^{115}$ While the early, 9th century graves display only moderate differences in quantity and quality of the burial objects, it is especially among the L'Incoronata graves of the 8th century BC that the most spectacular burials are found containing numerous items and special objects that were the prerogative of only a few persons in the settlement.

The birth of these local elites in southeast Italy was caused by endogenous changes within the various regional groups of the area. We have seen that population growth, colonization of inland areas and a substantial increase in interregional exchange contributed in a significant way to the emergence of lineages that dominated the local power play in the larger settlements. This happened during the middle and later 8th century BC. The recurring presence of arms in the burials of dominant males (cf. Tursi Sorigliano; fig. 4.16) suggests that martial prowess was one of the distinguishing features. External factors, however, acted as powerful catalytic agents in this process of increasing social stratification. Among these were, for instance, the rapid intensification of trade networks within southern Italy and the heavily increased links between exchange systems of southeast Italy and maritime trade networks involving distant areas such as the eastern Hallstatt district and Aegean Greece. It has, moreover, been observed that some settlements became pivots or nodal point in this process of intensification of Iron Age trade systems during the 7th century BC. We have seen that these were situated in spots where different exchange systems overlapped. Local elites of settlements that controlled these crucial spots in the system of exchange networks, could become elites of patently regional importance

An important settlements of the later 7th and early 6th century was Canosa in the north-Apulian Ofanto district. It played a crucial role in, for instance, the metal trade from Slovenia, amber from the Baltic Sea and perhaps salt and finely dyed cloth from Apulia. The settlement was pivotal in exchanges between the Adriatic regions of Italy, Dalmatia and various districts of south and central Italy. The baffling range of the networks in which Canosa directly or indirectly participated can be derived from the distribution of the Canosan matt-painted wares (fig. 4.17). The production area of these finely potted and miniaturistically decorated ceramics has been discovered in one of the highly dispersed habitation nuclei of the settlement (Canosa-Toppicelli). ${ }^{116}$ In close proximity to the kiln site an unusually large and wealthy tomb of the late 7th century was discovered (fig. 4.18). ${ }^{117}$ It is likely to represent the burial of a man of high status and contained a magnificent bronze belt, two bronze basins, a series of iron spits and a host of exquisitely made painted pots produced in the nearby kiln (Lo Porto 1992b,

113 Tumuli dating to the late 9th or 8th century BC have also been reported from the coastal area of northern Calabria (Zancani Montuoro 1971, 1976, 1979), eastern Basilicata (Lo Porto 1969) and the adjacent area of Apulia (Biancofiore 1973)

114 Szombathy 1917; Iker 1984.

115 Published in Chiartano 1977 and 1994.
116 Lo Porto 1992b, 72-74.

117 The tomb containing this high status burial of Canosa-Toppicelli was $2.70 \mathrm{~m}$ long, $1.20 \mathrm{~m}$ wide and $1.35 \mathrm{~m}$ deep; a highly spectacular tomb of a 7 thcentury'Daunian' lady has recently been found at the north-Apulian pot of Siponto-Cupola (Celestino Montanaro 2010). 


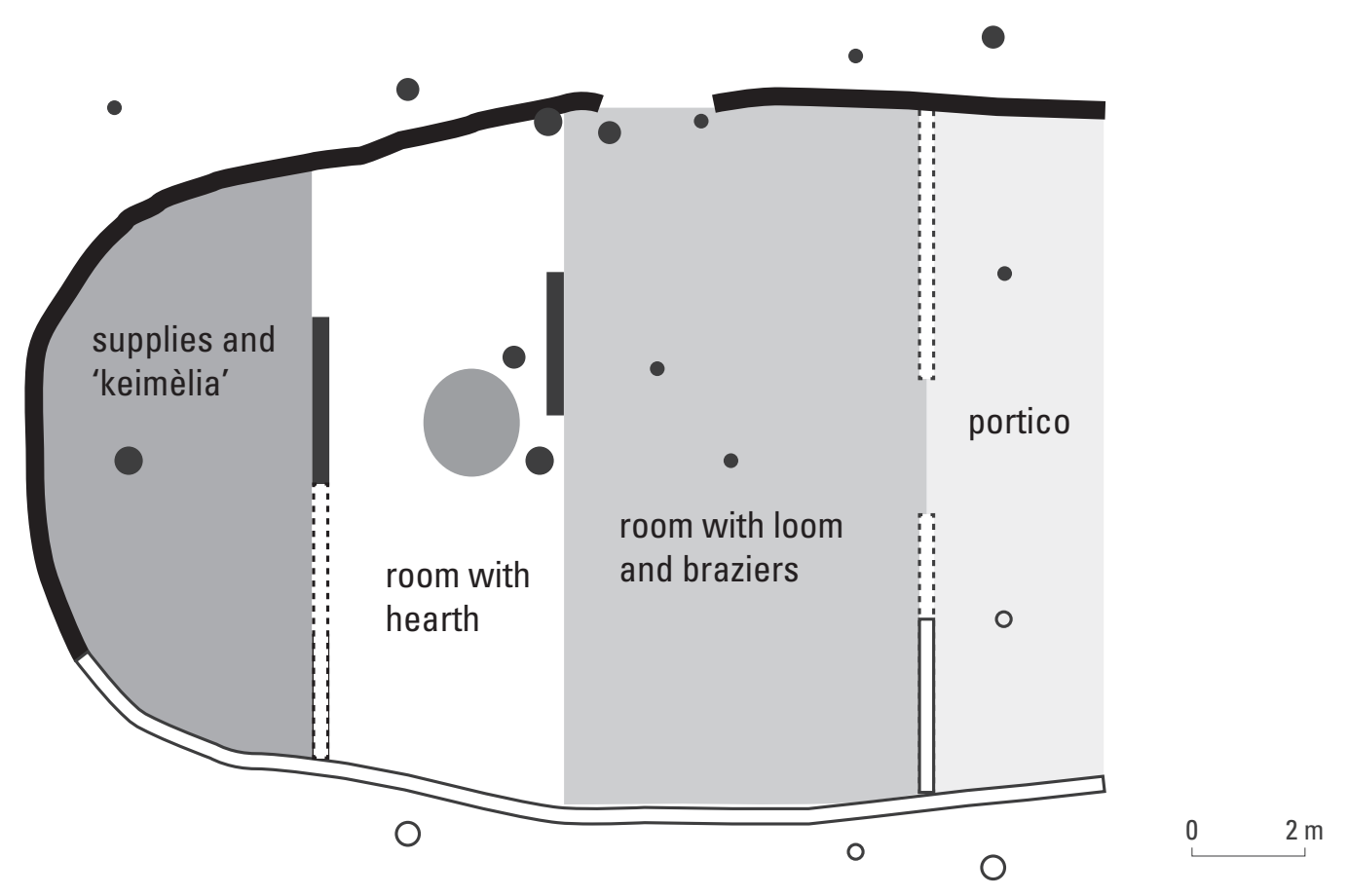

Fig. 4.19. Torre di Satriano. Large hut $(22 \times 12 \mathrm{~m})$ of local chieftain at the top of the $920 \mathrm{~m}$ high mountain (late 7 th century); adapted from Osanna 2009.

77-83). The man buried in that tomb was a chieftain of considerable substance. He is likely to have maintained interregional contacts and controlled the ceramic production of Canosa-Toppicelli. The products of this kiln site were found over large parts of Italy and in Dalmatia, Istria and Slovenia. A chieftain of probably comparable status at Satriano in the uplands of Lucania lived in an enormous hut measuring c. $22 \times 12 \mathrm{~m}$ (late 7th century). He lived on top of a $960 \mathrm{~m}$ high mountain, whereas most of his tribesmen had their dwellings in small hut settlements in the surrounding valleys (fig. 4.19). ${ }^{118}$

Canosa was (and continued to be) a settlement of considerable importance in the northern parts of Apulia. Spectacular graves of similar nature have been excavated in the mid to later 7 th-century necropolis at Alianello and the almost contemporary burial site of Chiaromonte-Sotto la Croce in western Basilicata (fig. 4.14). Here, local elites were buried with both elaborately painted pots and a lavish quantity of bronze and amber ornaments. ${ }^{119}$ These inland settlements probably controlled the overland route between Siris and southern Campania. Coastal settlements such as Siris, Metapontion and Otranto are likely to have performed comparable roles in the later 7th century BC, but since their burial customs (and their social systems) differed from those at Chiaromonte and Canosa the rise and the role of their elites are not so easily illustrated. The leading persons of these settlements may have manifested their status in partly or completely different ways. ${ }^{120}$

118 Osanna 2009 (the so-called 'residenza ad abside').

119 The burial customs at Alianello (and a number of other sites of western Basilicata) differed slightly from those in many other parts from southeast Italy: here the deceased was buried on his or her back in a distended position (usually the deceased was buried on his/her side in a contracted position).
120 Otranto (and the Salento district in general) has not supplied any evidence of burials for the 7th century BC; for a probable Greek-style elite burial from Siris dating to the later 7th century BC, see Bianco / Tagliente 1985, 61 fig. 30. 
We have seen above that in the earlier to mid 7th century BC southeast Italy had a series of burial grounds that differed from the traditional cemeteries of this region (section 4.3). Important discriminating elements were that they display a variety of burial customs (cremation and various forms of inhumation) and that nearly all the graves contain a very limited quantity of grave goods. ${ }^{121}$ Moreover, these burial sites were definitely outside the settlement areas. The earliest of these started as early as the first half of the 7th century $\mathrm{BC}$ and have probably correctly been interpreted as the burial grounds of resident Greeks and/or Greek-style burials. Some of these were small and short-lived (Brindisi, Torre Saturo), but in a few cases these burial grounds outside the settlement area developed into substantial necropoleis. It was especially from the last quarter of the 7th century BC onward that the quantity of burials in the Siris, Taras and Metapontion necropoleis began to increase exponentially. This suggests that from about that time onward larger, more populous, more coherent and more highly organized settlements came into being at these spots: the poleis of Siris, Taras and Metapontion. ${ }^{122}$

These late 7th-century and 6th-century necropoleis of the three emerging poleis differed in several respects from both the contemporary necropoleis in the Aegean-Greek world and the preceding phases of the south-Italian Greek-style cemeteries which reflected various types of burial customs found in Aegean Greece. The best information comes from Taras where thousands of tombs have been discovered. This happened when the modern city spread over the ancient burial grounds during the late 19th and 20th centuries. ${ }^{123}$ Metapontion, however, is likely to have been a very comparable case. ${ }^{124}$ What is striking in these cemeteries is that (1) the now uniformly used rite is inhumation, that (2) the deceased are invariably buried in rectangular trenches in the ground (fossa graves), ${ }^{125}$ and that (3) the burial goods often consist of considerable quantities of richly decorated ceramics (initially predominantly Middle to Late Corinthian painted wares).

These same three features are currently encountered in slightly earlier and contemporary burial grounds of the non-Greek world of southeast Italy. Since south-Italic natives can be surmised to have been among the early inhabitants of these coastal settlements, ${ }^{126}$ there is a good chance that part of the burial customs of the emerging Greek poleis of southeast Italy was inspired by the non-Greek world of southeast Italy. Whilst the location of the cemeteries of Taras, Metapontion and Siris (outside the settlement area) and the spatial arrangement of the burial grounds (family groups within a fairly close knit necropolis) were rooted in originally Greek traditions, the lavishness of the grave goods, the abundance of painted pottery and the custom of inhumation in fossa graves were all quite characteristic elements of the non-Greek populations of southeast Italy during the middle and later 7th century BC. Therefore, the burial customs of the emerging Greek poleis of the late 7th and early 6th century BC were probably a mix of basically Greek and originally south-Italic 'native' features. They stress that both Greeks and non-Greek were involved in the genesis of the to all appearances Greek poleis in southeast Italy. The Greeks of southeast Italy, therefore, were considerably less 'Greek' than they themselves wished to believe and than they propagated to others from the 6th century onward.

121 The small quantity of grave goods does not necessarily mean that the people buried there were poor. Since nearly all the burials in these early Greek or Greek-style necropoleis contain only a few objects, the deceased (or their descendants) were simply no big spenders in the funerary sphere.

122 Similar developments are likely to have taken place at Sybaris. The burial sites of this settlement are still covered by tons of mud.

123 See, for instance, Lo Porto 1960, Cento Anni and Neeft 1994.
124 For a good summary on the burial grounds of Metapontion, see De Juliis 2001, 117-128.

125 These most impressive fossa graves contained a limestone sarcophagus (tomba a sarcofago), most of them were lined by limestone slabs (tomba a lastroni), the most simple specimens were just rectangular trenches (tomba a fossa semplice).

126 Yntema 2000 and 2011. 
This observation raises questions concerning the social structures in the Greek speaking communities in southeast Italy during the Iron Age. The relatively few individuals (traders, mercenaries, craftsmen) who exchanged Greece for southeast Italy in the late 8th and early 7th centuries, left their original social world behind and functioned within non-Greek contexts: these earliest Greek immigrants were linked in some way with indigenous groups amongst which they lived and worked. The appearance of Greek or Greek-style burial grounds in the first half of the 7th century BC suggests that things began to change in a limited number of settlements of southeast Italy: people who are buried together tend to see themselves as a social unit and are perceived as such by others. But as we have seen above, it was especially in the later 7th century BC that the burial grounds of Siris, Taras, Metapontion (and possibly Sybaris) became larger and more densely occupied and began to display the spatial organization and coherence of true cities of the dead. In some cases there is reason to assume that larger groups of Greeks migrated. This happened mainly in the second half of the 7th century. The foundation story of Siris, for instance, indicates that a series of households left the town of Colophon in Asia Minor around 650/640 BC and founded the new settlement in southeast Italy (Lombardo 1986). ${ }^{127}$ The earliest phase of Metapontion was closely comparable to early Siris. ${ }^{128}$ The 7 th-century settlement phases that preceded the Greek poleis of southeast Italy, therefore, did not have the social structure commonly assigned to Greek towns. It was not until the late 7th century that the first signs of a truly coherent, fairly populous community make their appearance at Metapontion (e.g., sacellum C1, wooden predecessor of the ekklesiasterion, earthworks surrounding the settlement). Other signs pointing at new, urban communities were the completely new and rigidly orthogonal layouts of Sybaris, Metapontion and Taras (and perhaps Siris, dating to approximately the second quarter of the 6th century BC. They stress the birth of an entirely new social order (see chapter 5).

In the above passages on settlements and burial grounds hints have been given concerning the social structure of the indigenous communities of southeast Italy. The settlement clusters consisting of five to eight contemporary huts each suggest that the family group was an important social unit. Comparable clusters of graves can be encountered, but there are also larger cemeteries indicating the presence of larger, more complex social units such as clans. Family groups were probably part of a clan that inhabited a specific section or territory within the settlement area and buried its dead in the clan necropolis located in and near the same area.

The most intimate images of an Iron Age indigenous society of southeast Italy can be found in a unique body of documents from the north-Apulian Tavoliere plain. These are the so-called 'Daunian stelai' of which some 2.000 fragments belonging to c. 1.200 different specimens have been found at the coastal site of Siponto (figs 4.10 and 4.20). The earliest stele dates to the later 8th century, but most of them belong to the 7th and 6th centuries BC. ${ }^{129}$ These stelai are rectangular limestone slabs of varying dimensions. Their height is between 0.45 and $1.30 \mathrm{~m}$, their width usually varies between 0.25 and 0.60 $\mathrm{m}$ and they are 0.05 to $0.10 \mathrm{~m}$ thick. A stylized round or spool-shaped human head was attached to the upper side of each slab with a pin, giving the stele an anthropomorphic character. The stelai were

127 The archaeological evidence suggests that the first traces of Greek presence were some 40 to 50 years older than the foundation story of the apoikía tells us. Since the foundation stories are basically origo myths, it is difficult to separate fact from fiction and reshaped past from invented past in these stories (Yntema 2000).

128 The earliest phases of Metapontion are MetapontoAndrisani and Metaponto-Lazzazzera. There is no information on the mid 7th-century phases of the settlements of Taras and Sybaris.

129 For catalogue and good photographs of the 'Daunian' stelai, see Nava 1981 and 1988; The 6th century, of course, is discussed in the following chapter on the Archaic/Classical period. In north Apulia, Iron Age situations continued to exist to within the 3rd century BC. See section 4.6 (this chapter). 


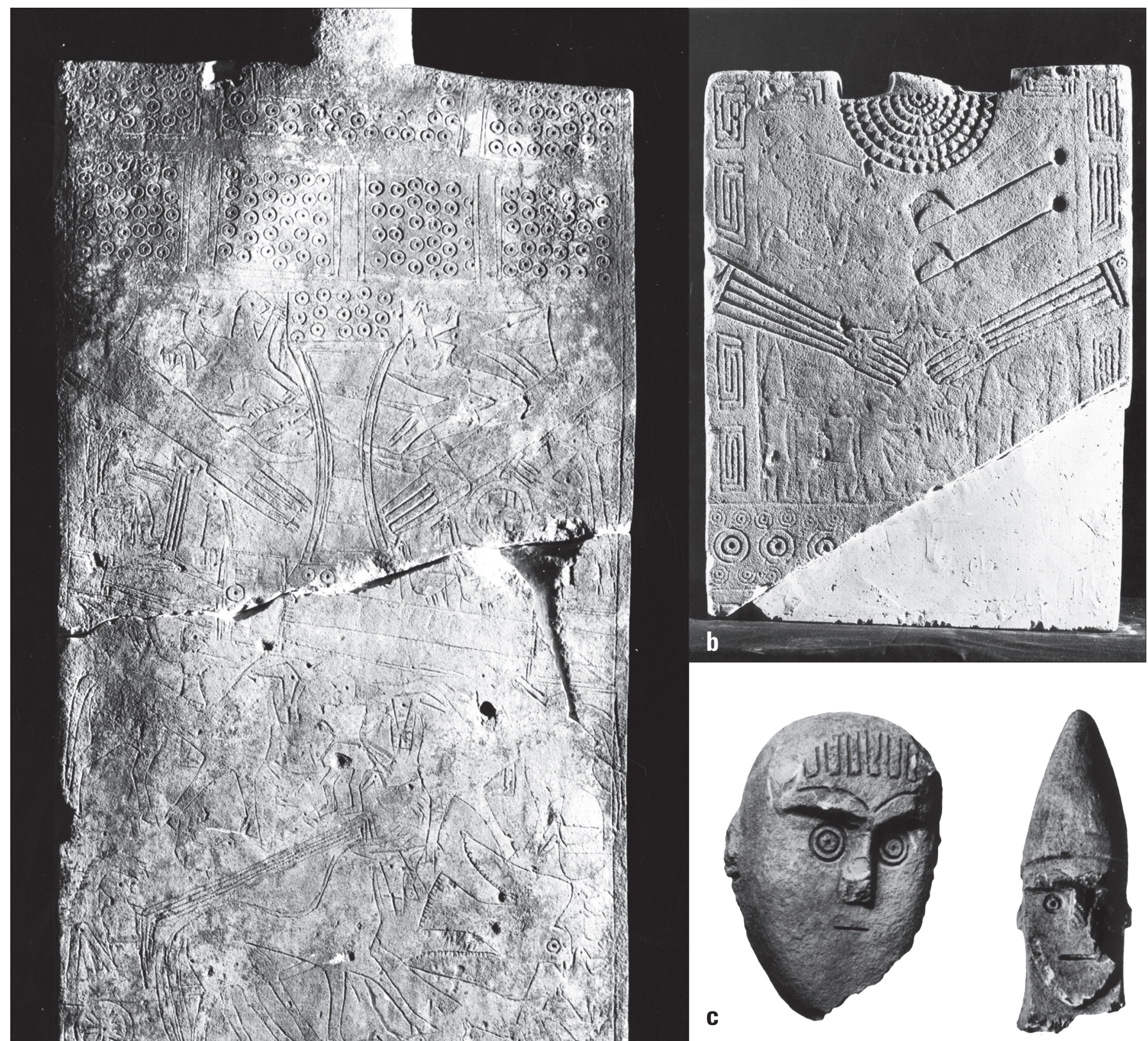

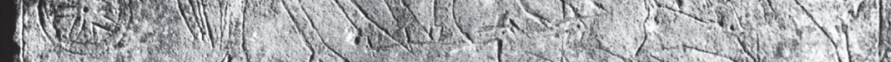

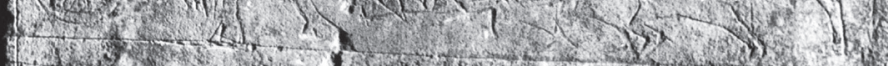

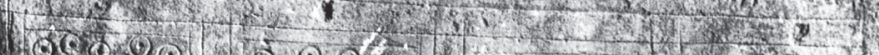

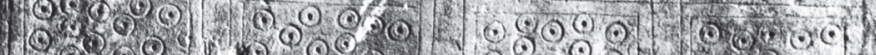

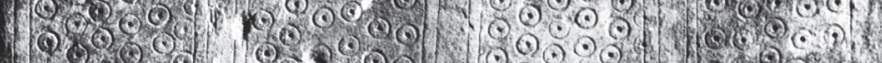

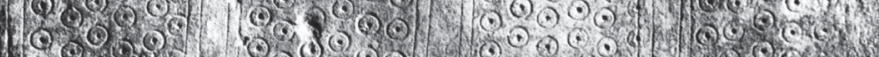

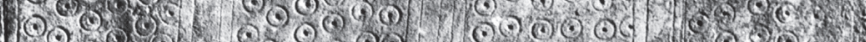

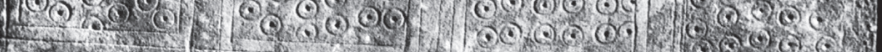
If

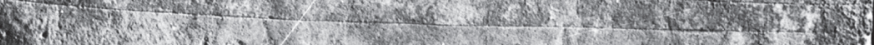

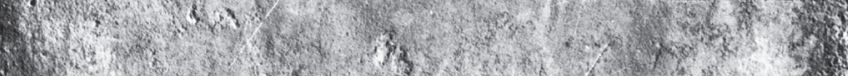

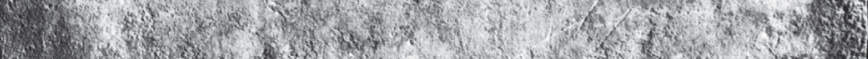

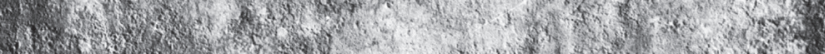

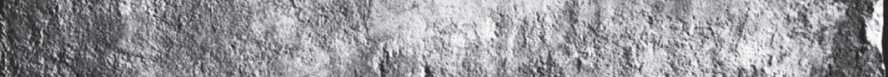

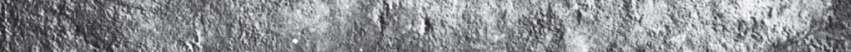

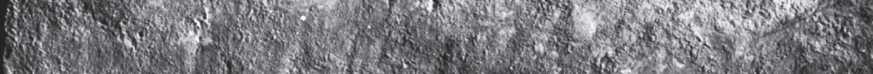

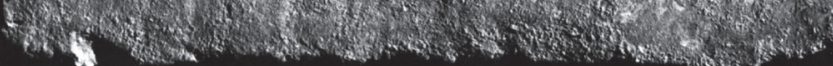

Fig.4.20. Siponto, (Tavoliere district, northApulia), schematic representations of both sides of a warrior stele (e) and 'civilian' stele (f) a. large warrior stele (7th century): $\mathrm{d} / \mathrm{g} / \mathrm{h}$. scenes from 'civilian' stelai (late 7th-6th centuries) c. heads of stelai. Courtesy Ufficio Staccato Soprintendenza, Foggia. 

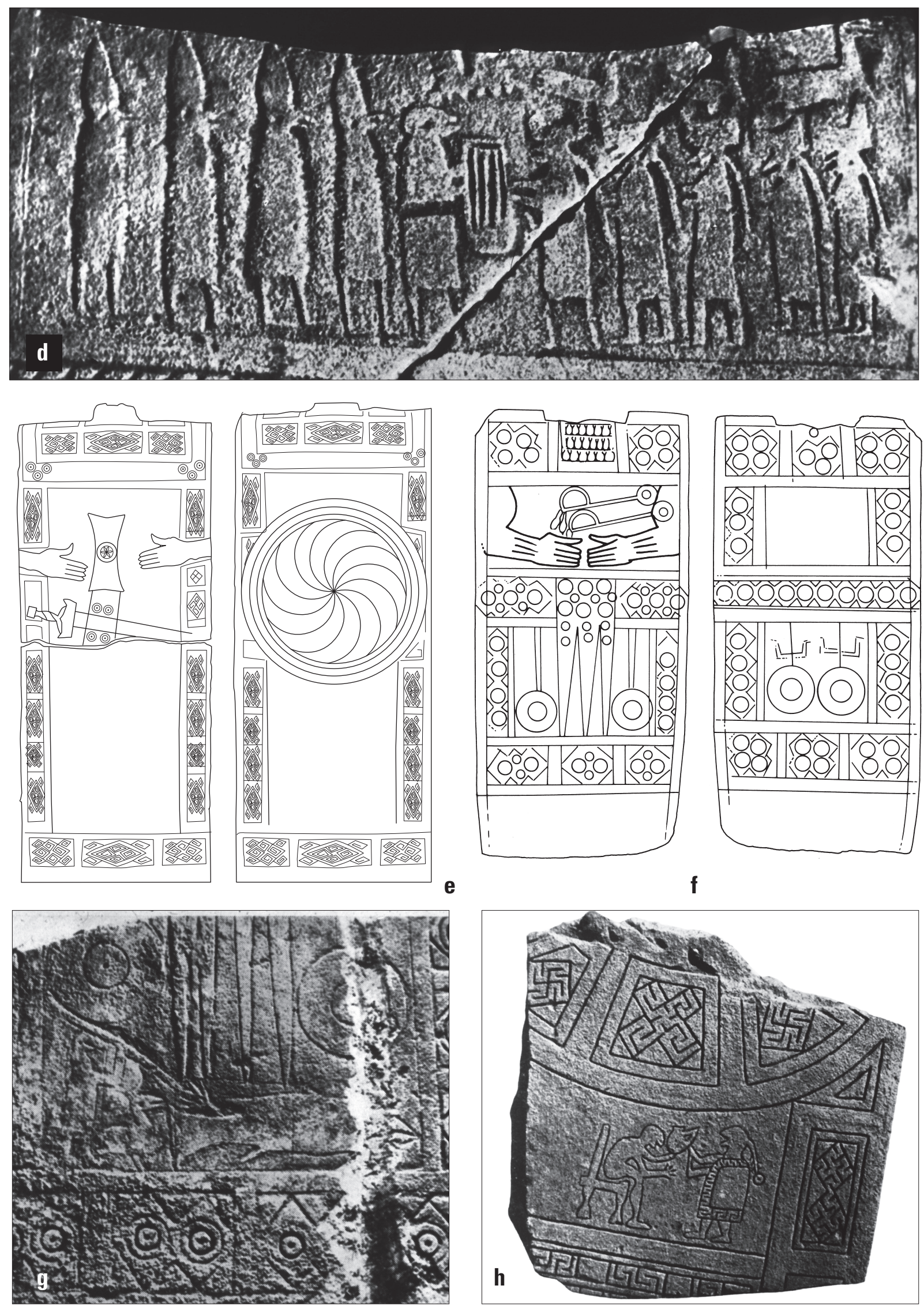


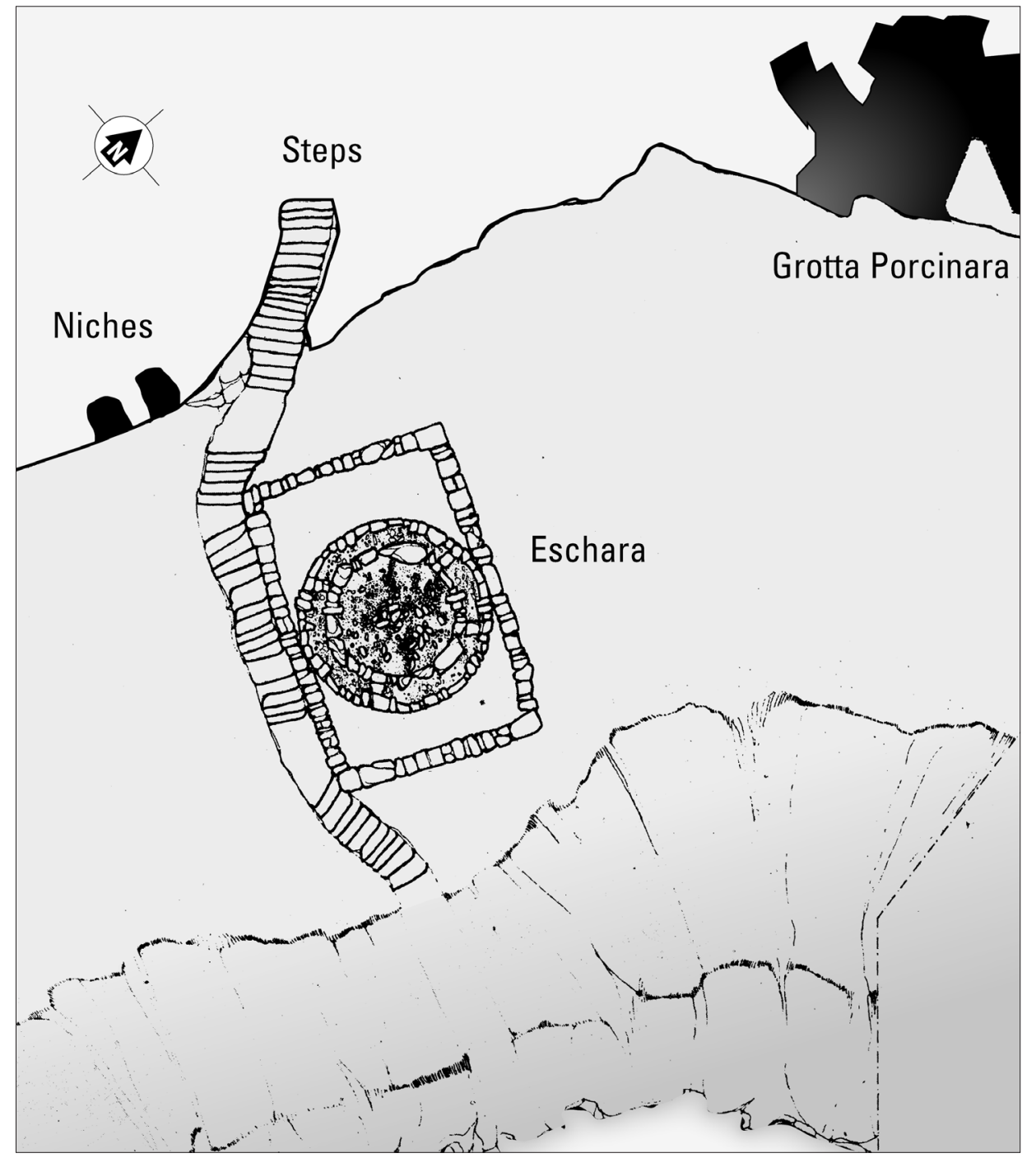

Fig. 4.21. Leuca

(Salento district, south-Apulia): plan of altar (eschara), 7th/early 6th century BC (after D’Andria 1978).

placed on top of small tumuli and served as grave markers. Their most attractive quality, however, is their incised (and once painted) decoration. On the strength of the incised decoration, two basic types can be discerned. The more common type shows the arms of the deceased, richly decorated clothes, a belt and quite a number of ornaments such as beads, fibulae and discs which were attached to a belt. The rarer type displays the arms and a sword on the front, and a large circular shield on the back. In dozens of cases the areas between these features were filled in with scenes depicting Iron Age activities. ${ }^{130}$ We see, for instance, people sailing boats, men catching large fishes and birds, women sitting at the loom (?), furniture, feasts/processions, hunting parties and warfare. ${ }^{131}$

The Daunian stelai from Siponto constitute a unique Iron Age picture book. Other sites of northApulia may have had similar collections of limestone monuments, but only few specimens of these have survived. ${ }^{132}$ Comparable anthropomorphic grave markers have been found at more northerly sites

130 Silvio Ferri who found these stelai, being raised in a strongly diffusionist tradition, interpreted several scenes as 'Daunian' versions of Indo-Europaean myths (e.g. scenes from the Trojan war). His articles on these objects appeared mainly in Bolletino d'Arte between
1962 and 1967 (reprinted in Nava 1988).

131 Nava 1981, stelai 518 and 846.

132 For 'Daunian stelai' from other sites, see Nava 1988, 171-198, and Nava 2011. 
of the Adriatic, ${ }^{133}$ while incised stelai are also found at the coastal site of Novilara (the Marche region, near Pesaro) and in Istria. ${ }^{134}$ Obviously, such grave markers were at home in districts on the central and northern Adriatic between the 7th and the early 5th century BC. Some of the scenes depicted on the Daunian stelai (notably the processions), moreover, show affinities with those on the bronze situlae produced in the Este region on the northern Adriatic. ${ }^{135}$

The Siponto stelai were probably not representative of the whole community living on the spot. Some of the people who died there, did not receive a formal burial or were interred in unmarked graves. But the extant grave markers demonstrate that there were at least two distinct groups: the sword-bearers and the non-sword bearers (fig. 4.20e). The former were all men, the latter group probably consisted of both males and females. Among the non-sword bearers were men with tall pointed hats (fig. $4.20 \mathrm{~d}$ ). These feature prominently alongside the bard and a string of women in feasting or processions scenes. They were obviously men of substance without belonging to the sword bearing elite. The seriation of the stelai in five more or less chronologically subsequent stylistic groups by Nava ${ }^{136}$ moreover, indicates quite thorough social changes in northern Apulia during the time the stelai were made. Whilst sword bearers account for ca. $40 \%$ of the stelai in the early group (7th-century), their percentage decreases to c. $25 \%$ in the 6 th-century groups and dwindles to a misery $1 \%$ in the most recent late 6 th/early 5 th century group. ${ }^{137}$

The stelai indicate that the Iron Age tribal world of northern Apulia (and perhaps of large parts of southeast Italy) was far more complex in social respect than the simple division between elite and non-elite. The men with the pointed hats frequently encountered in procession scenes, for instance, may have been priests or shamans. Thorough analyses of both the stelai and the numerous Iron Age necropoleis of southeast Italy have not yet been carried out. They may well reveal a social system with rather intricate inter-group relations.

Some of the scenes on the Daunian stelai can be suspected of showing religious activities and hinting at beliefs. In addition to the feasts or processions mentioned above, the 7th- and 6th- century stelai display scenes including persons with bull's heads and images of monstrous creatures. ${ }^{138}$ Among the few figurative scenes on the Iron Age matt-painted pots of southeast Italy some have been interpreted in a similar vein. ${ }^{139}$ These iconic sources - if they have been interpreted correctly - are practically the only traces of Iron Age religious activity. Though the rites that bound the local communities together must have been performed in public (cf. the 'Daunian' stelai), hardly any traces of sacred places or rituals have been found in the archaeological record hitherto.

Many rituals were small-scale activities. They consist of dumps of food and/or (smashed) pottery that are often simular to rubbish pits. ${ }^{140}$ Traces of religous activities on a larger scale stem from only two sites. The first set was discovered at Francavilla Marittima (in the foothills surrounding the plain of Sybaris). Here a group of three wooden buildings was erected around $700 \mathrm{BC}$ which display a mix of Greek and indigenous features. ${ }^{141}$ The second set of traces of religious activities has been found Leuca (Salento peninsula). On Salento's southernmost cape an indigenous sanctuary has been excavated of

133 E.g. the Capestrano warrior in the Abruzzi region, the Numana warrior in the Ancona area.

134 For stelai from Novilara, see Brizio 1895; for Istrian Iron Age stelai, see Fischer 1984.

135 For the Este situlae, see Frey 1969.

136 Nava 1981.

137 Yntema 1983.

138 Ferri 1966, fig. 12; Nava 1981, stele 612.

139 Cf. ceramics from western Basilicata (Neutsch 1961;
Kilian 1967)

140 For suchs ritual deposits, see Burgers / Crielaard 2011, 69-71; see also D'Andria (forthcoming) on Iron Age ritual deposits from Vaste; an overview of the sites which may have been Iron Age cult places (but the evidence is sometimes extremely thin), see Mastronuzzi 2005, 136-141.

141 Kleibrink 2005 and 2006. 
which the earliest traces date to the late 8 th or early 7 th century BC. ${ }^{142}$ The site is situated on a cliff above the sea. It consisted of a rounded altar (eschara) in front of a cave (fig. 4.21). Both spots can only be recognized as sacred places because objects have been deposited here that preserve well in the archaeological record. Mixed with the ashes of the eschara at Leuca, for instance, were animal bones and ceramics dated between the late 8th/early 7th and the beginnings of the 5th century BC. ${ }^{143}$ Generally speaking, therefore, cult places can only be recognized in southeast Italy when datable objects were deposited by the people of the past who visited the spot.

However, it was only after the Iron Age that this probably originally Greek custom in the ritual sphere won general acceptance in most districts of southeast Italy. It happened from the second half of the 6th century onward. But spots that are recognized as cult places frequented from the later 6th century onward, may well have functioned much earlier than seems to be the case at present. Caves, wells and springs are likely to have been sacred places in the Iron Age in much of southeast Italy. Since the Iron Age people who possibly frequented these places, left no objects behind that survive to the present day, this can be nothing more but an educated guess.

\subsection{REGI O N A L I Z A T I O N A N D C R A F T}

In the preceding sections of this chapter we have encountered 7th-century 'Daunian' stelai and 'Canosan' matt-painted pots. The use of these adjectives, of course, indicates that those artifacts are characteristic of respectively 'Daunia' (basically a Greek label for northern Apulia) and Canosa (the Italian name of a site in the transition zone between north and central Apulia). Obviously limestone grave markers with incised decoration and pots painted in a particular style were not found all over southeast Italy, but were specific products made exclusively in one single district or even one single settlement of this vast area. In fact, one of the features that characterize southeast Italy during the Iron Age (and probably Italy in general), is the increasing 'regionalization' of material culture during the 8th and 7th centuries BC. While, for instance, there is little variety in the matt-painted ceramics of the 9th century BC over large parts of southeast Italy, regional features become steadily more pronounced during the 8th century. This resulted in a host of regional or even local schools in the 7th century BC. This process of 'regionalization' is not just apparent in the production of ceramics, but can also be encountered in several other fields. It can also be observed in, for instance, metal production, funerary customs, character of the dwellings and settlement types. This regionalization in which each district of the macro-region southeast Italy developed a series of features that were characteristic of that district only, resulted in the so-called 'cultural groups' that have been presented in chapter 3 .

The causes of these diverging trajectories in shaping material culture were many. First and foremost among these were the colonization activities and the increasingly sedentary character of the Iron Age groups. An initially predominantly coastal population with a basically coastal communication system colonized the various geographical units in the inland areas of southeast Italy. In addition to coastal communication, there was now intense communication between the coast and inland groups that had split off. However, intercommunication between the various inland groups was limited. A second factor stimulating regionalization in southeast Italy was the exponential increase of trade and exchange, not only between different areas within southeast Italy, but especially with outsiders such as Greeks, 'Hallstattians' and the Sabellic groups living in the present-day regions of Campania and Molise. As we have

142 D’Andria 1978.

143 In inland Salento there is a second cult place (no traces of an altar) in a cave the first datable traces of which date to approximately the mid 7th century: at Ruffano (Grotta Trinità; Archeologia dei Messapi, 195-196) 

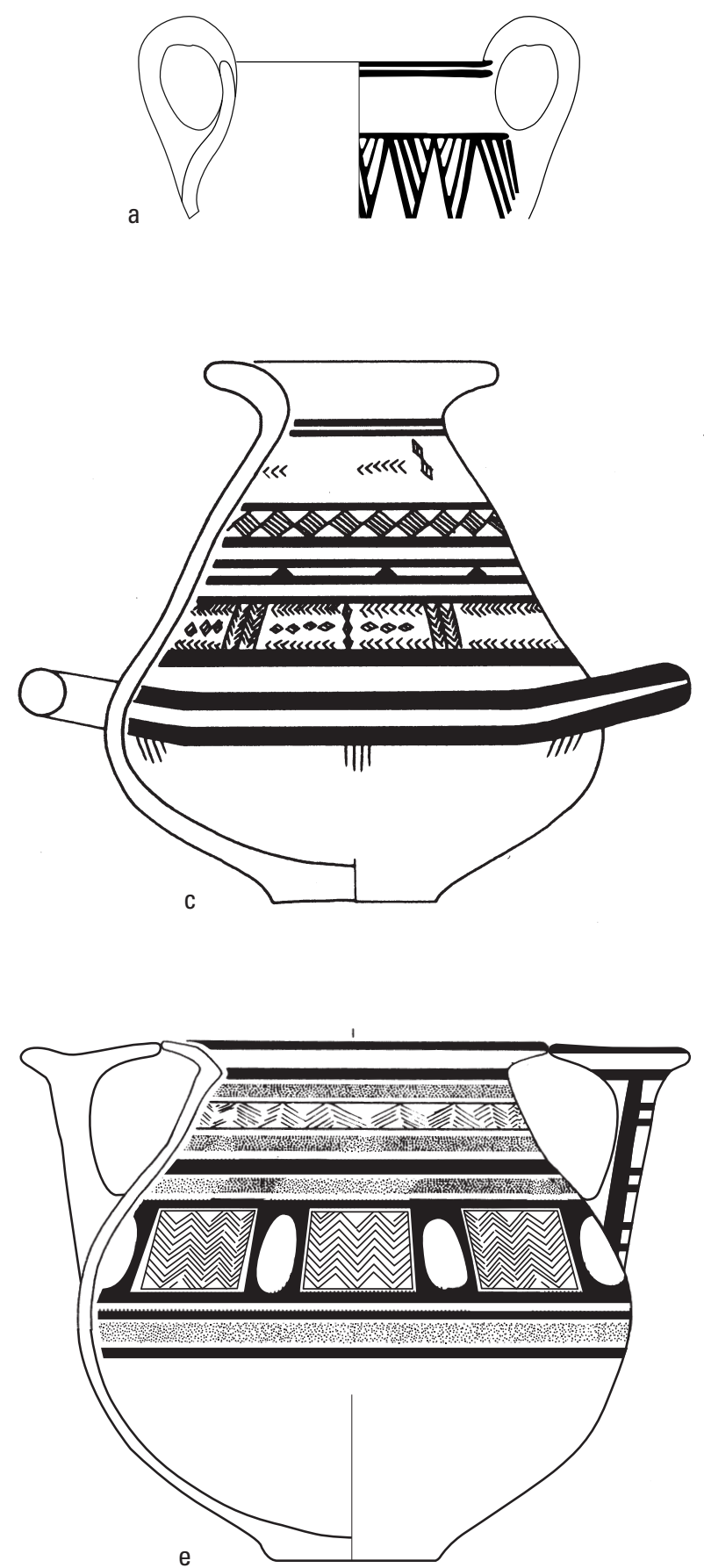
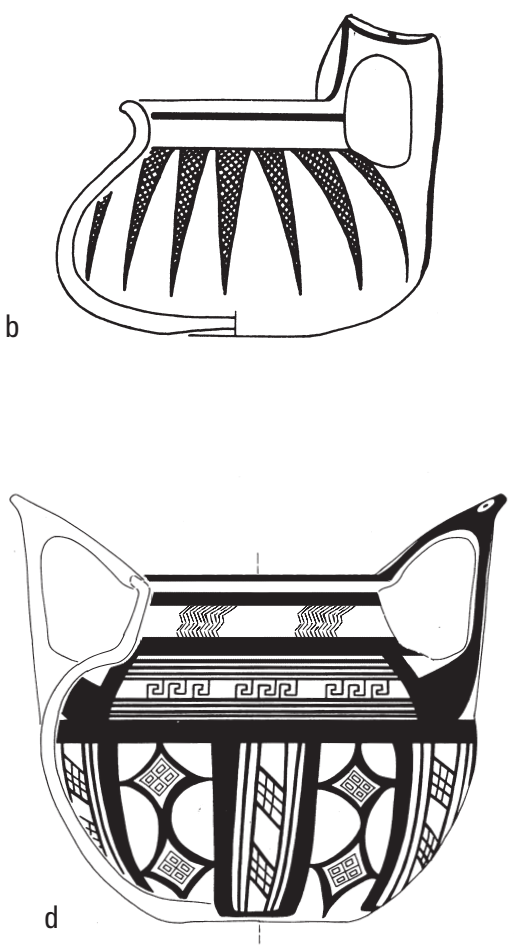

Fig. 4.22. a. High-handled pot found at Otranto, but made in the Devoll area (southern Albania); b. small jug from Otranto with Devoll patterns (local production); c. Salento matt-painted pot with Greek chevrons from Taranto (later 8th century; Borgo Nuovo deposit); d. Salento matt-painted pot completely covered with ornaments of Greek origin (from Otranto; early 7th century ); Salento matt-painted pot with bichrome decoration (from Otranto; late 7th century $\mathrm{BC})$

seen above, the coastal area on the Gulf of Taranto, for instance, had very intense contacts with Greeks from the late 8th century onward. Small groups of Greeks even lived there on a permanent basis.

This culture contact resulted in culture change. The Salento matt-painted pots of c. 700 BC differ markedly from those made around $750 \mathrm{BC}$. The vessels produced around $700 \mathrm{BC}$ display an almost completely new set of motifs which have a mostly Greek-geometric pedigree (fig. 4.22d). Whilst the material culture of the coastal area on the Gulf of Taranto displays signs of these contacts with Greeks, northern Apulia with its strong links with the northern Adriatic and eastern Hallstatt world shared a particular set of features in its material culture with these vastly different districts (e.g. fibulas, anthropomorphic and incised grave markers in stone). Intensive contacts with external groups having a vastly different material culture was one of the causes of increasing differences between pots, metal objects, 
funerary customs, habitations and settlement types of the various districts of southeast Italy. Each district of southeast Italy developed its own cultural bricolage that could consist of traditional features, elements organically developed within the district and features adopted from areas with vastly different cultural traditions. The latter could come from neighbours (e.g. Campanians, Sabellians) or oversea contacts (e.g. various types of Greeks, the Picentes in the Marche region, the Iapodes of Dalmatia and the east-Halstattians of Istria and Slovenia).

These regional differences did not occur exclusively in the field of material culture, but also occurred in the realm of concepts, notions and ideas. They are, however, particularly evident in objects, because material culture is more adaptable. Moreover, external influence can be observed more easily in an excavated object than in the archaeologist's construct of the social aspects of a particular group. Whilst around $750 \mathrm{BC}$ (i.e. before the drastic changes described above) the differences in craft, economy, religion and social systems between the various districts of southeast Italy were probably fairly limited, they differed vastly by about 600/550 BC. Around $750 \mathrm{BC}$, for instance, the elites of both Canosa and L'Incoronata were made up of the leaders of a few dominant lineages. By about $600 \mathrm{BC}$ the leaders at Canosa were great chieftains comparable to the warrior chiefs of the northern Adriatic or the Hallstattian world, who lived in oval huts and practiced religion in a way that left no traces in the archaeological record. At the same moment leading families of the former indigenous settlement of L'Incoronata (abandoned in c. 600) were among the - to all appearances - Greek elite of the polis of Metapontion, lived in a Greek style in Greek houses and deposited their votive offerings in both urban and rural sanctuaries. The regionalization was not just a case of increasing differences between pots and fibulae from different districts: it also affected the social patterns, the beliefs and the world views of the groups living in the various districts of southeast Italy.

The most abundant evidence for the regionalization process in southeast Italy is supplied by the ceramics. Various types of ceramics were produced here during the period under discussion. But it is especially the often lavishly decorated matt-painted pottery of this area that can be analyzed for this purpose. The roots of these wares lay in the late phase of the Bronze Age with the birth of the handmade and slow-wheelmade matt-painted South-Italian Protogeometric wares (see chapter 2.4). In the 10th and 9th centuries $\mathrm{BC}$ these wares, decorated with a matt dark brown paint, changed only very gradually and continued to be very similar all over southeast Italy (fig. 2.12). But when internal colonization, increasingly frequent interregional exchanges and contacts with distant populations gained momentum in the course of the 8th century, various regional styles came into being which differed from each other in many respects.

The Salento peninsula was the first district to break away from the mainstream by adopting patterns derived from the matt-painted pottery of south-Albania and northwestern Greece (fig. 4.22a and b). ${ }^{144}$ This happened before the middle of the 8th century. From about the 3rd quarter of the same century patterns derived from Greek Late Geometric pottery can be observed on Salento matt-painted pots (fig. 4.22c). These grew into a flood in the early 7th century when the painted wares were almost completely covered by such patterns (fig. 4.22d). Soon bichromatic decoration with an alternation of dark brown and reddish brown paint almost completely replaced monochrome painting in dark brown (fig. 4.22e), while the originally modest ornaments of 'Albanian' and Greek descent developed into elaborate patterns covering large parts of the pots.

Similar developments occurred in other districts of southeast Italy. There was a general tendency to adopt new patterns of both 'Albanian' and Greek origin. Since Albanian Devoll wares have mainly

144 These are the so-called Devoll wares; for further litera-

ture see note 38 . 

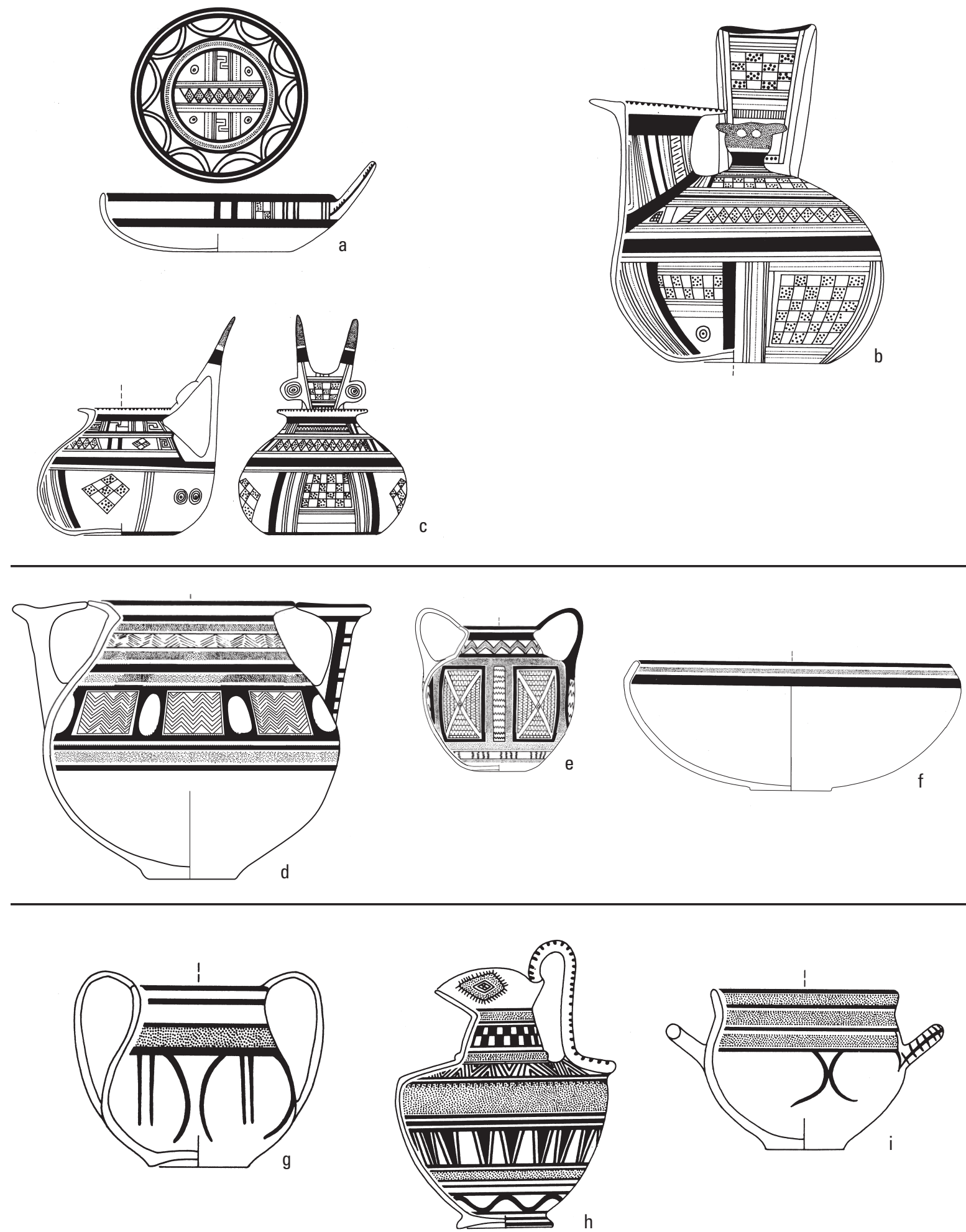

Fig. 4.23. Shapes and ornaments of various districts: a-c. bowl, askos, bag-shaped jug from the Ofanto district (late 7th century); d-f. conical necked jar, olletta and scodella from Salento district (late 7th century); g-i. olletta/kantharos, oinochoe and cup (native version coppa a filetti) from western Basilicata (late 7th/early 6th century). 


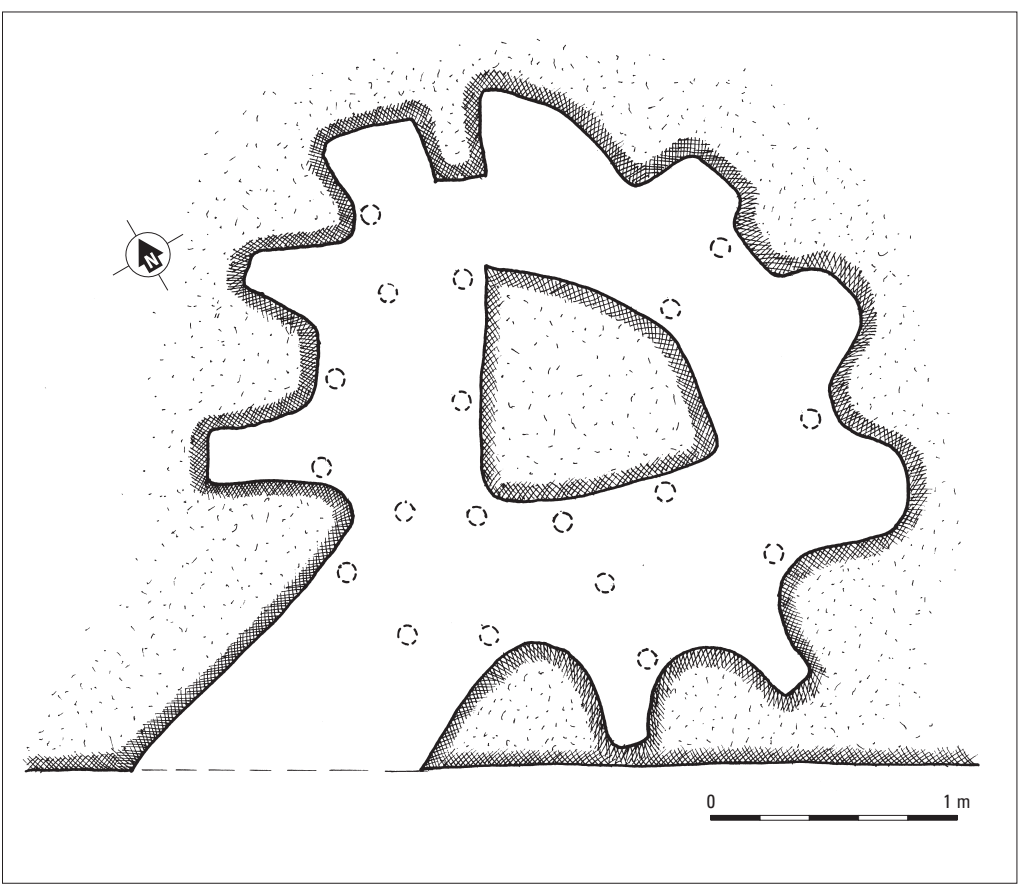

Fig. 4.24. Montescaglioso (southeast Basilicata), kiln A: plan of combustion room with central pillar and praefurnium damaged by the bulldozer; rounded holes communicating with the now lost firing room in which the pots were stacked before firing; 6th century BC (adapted from Lo Porto 1988/89, fig. 97).

been found at the site of Otranto, a central role in the diffusion of these new patterns may have been played by that site or by the Salento district in general. The second almost general trend is that the decoration that was limited to the upper half of the pots during the 9th and 8th centuries, spread all over the matt-painted vessels in the 7th century BC. The exceptions to this rule were western Basilicata and northern Calabria where the upper parts of the pots were usually adorned with horizontal bands, whilst the lower parts of the vessels rarely sustained elaborate decoration (fig. 4.23.g-i). The adoption of bichromy was the third trend that can be observed in large parts of southeast Italy. Buoyantly bichromatic ceramics were made in southern Apulia and Basilicata. The potters in the valley of the river Ofanto used bichromy only sparingly during the 7th and early 6th century, ${ }^{145}$ whilst the coastal strip of central-Apulia (Bari district) and the north-Apulian Tavoliere stuck to exclusively monochrome matt-painted decoration to within the 5th century BC. ${ }^{146}$

Alongside these general lines shared by the various schools of pottery production, each district developed its own set of characteristics. Sometimes even local workshops can be recognized. ${ }^{147}$ Ornaments and shapes are the most distinctive elements. The way the ornaments are arranged on the pots (the 'decorative syntax') is equally characteristic of a specific area. As for the forms, both the Tavoliere and Canosa (Ofanto district), for instance, preferred spherical jars, bag-shaped jugs and high-handled jugs and bowls (the so-called attingitoio). The askos was a rare form in most districts of southeast Italy, but from the late 7 th century onward this shape became enormously popular at Canosa in the Ofanto

145 Canosa and other sites in the valley of the Ofanto started to produce strongly bichromatic wares from the last third of the 6th century onward (see Yntema 1990, 250ff: Ofanto Subgeometric II).

146 The Bari area adhered to monochrome decoration till the slow-wheel made matt-painted wares of the district were replaced by regionally produced quickwheelmade wares with banded and vegetal decoration.
This happened between the c. 525 and 475 BC. In the Tavoliere district matt-painted pots with bichromatic decoration appeared alongside monochromes in burials dating to approximately 475/450 BC.

147 For instance, the local workshop of Oppido Lucano in eastern Basilicata (see Lissi Caronna 1976; Yntema 1990, 314-317) 
district (fig. 4.23b). ${ }^{148}$ In Salento the most current forms were conical necked jars, bowls with inturned rim and small high-handled pots (fig. 4.23d-f), whilst western Basilicata added new, basically Greek shapes such as the wine cup and the oinochoe to its repertory of traditional forms during the later 7th and early 6th centuries BC (fig. 4.23g-i). In the field of ornaments and decorative syntax, the Basilicata districts continued to adhere to the traditional schemes: horizontal bands or zones on the upper halves and only limited decoration on the lower halves of the pots (fig. 4.23.g-i). Salento preferred large, elaborate ornaments in large more or less rectangular fields (panel decoration), whilst the 7th to early 6th century ceramics of Bari area and the Ofanto district surrounding Canosa had a horizontal zone on the upper half and panel decoration on the lower half of the vessel containing almost miniaturistically painted ornaments (fig. 4.23.a-c). ${ }^{149}$

These matt-painted wares of southeast Italy were shaped by a variety of methods. But the potters never used the quick potter's wheel..$^{150}$ The vessels were fired in closed kilns in an oxidizing atmosphere. Kilns used to produce matt-painted wares have been found at various sites (fig. 4.24). ${ }^{151}$

Matt-painted was not the only class of ceramics produced in Iron Age southeast Italy. Between the 10th century and the middle of the 8th century BC, black to dark brown impasto pottery was far more common than the matt-painted wares. This is apparent in, for instance, the tomb contents of the two large well-published necropoleis of the early Iron Age: Sala Consilina and L'Incoronata. ${ }^{152}$ The shapes of these impasto vessels are usually very similar to those of the matt-painted wares: jugs, bowls, globular jars and conical necked jars were foremost among them (fig. 4.25a). Often these pots were elaborately burnished. These ceramics were widely used in habitation areas, but they could also accompany the deceased in the grave. Much coarser and more thick-walled impasto jars were used for storage and for the burials of very young children (fig. 4.25b). These have no parallels in the mattpainted wares. ${ }^{153}$ This purely utilitarian form was already produced in the Bronze Age and continued to be made in large numbers in most parts of southeast Italy during the 6th and 5th centuries BC. ${ }^{154}$

148 This popularity of the askos at Canosa lasted to into the 2nd century BC (see Yntema 1990, 279 ff.: Listata III); they were exclusively made for funerary purposes.

149 For detailed studies on regional styles of matt-painted ceramics of southeast Italy, see La Genière 1968 (western Basilicata), De Juliis 1977a (northern Apulia) and 1995 (central Apulia), Yntema 1979 (Canosa and Ofanto district); Yntema 1981 (Salento), De Juliis 1995 (present-day Bari province). General overview in Yntema 1990.

150 The base of the pot was sometimes made in a mould. The upper half of the body, neck, rim and handle were all shaped separately, partly by hand, partly with the use of a slow potter's wheel. The constituent parts of the pot were pasted together when partially dry.

151 A relatively large and well-preserved specimen stems from the site of Montescaglioso (Lo Porto 1988/89, 384-386). It was more or less round having a diameter of over $3.00 \mathrm{~m}$, while its combustion room had a central pillar and radial walls. The heat of the fire in the combustion room could reach the upper firing room in which the pots were stacked, by means of a series of 8 $\mathrm{cm}$ wide holes. The Montescaglioso kiln A shown in fig. 4.24 is unusually large. Whenever the diameter of the kiln can be reconstructed, it varies between c. 1.50 and $2.00 \mathrm{~m}$.

152 For the Iron Age tombs of Sala Consilina, see Kilian 1964 and 1970 and La Genière 1968; for the tombs of San Teodoro-L'Incoronata, see Chiartano 1977, 1994, 1996.

153 There is little evidence for the production of impasto wares. An early 7 th century kiln of Oria (Salento) produced both matt-painted wares and impasto storage jars. Most Iron Age kilns discovered hitherto date to the 7th century BC. In this later part of the Iron Age burnished impasto was made in only limited quantities and vanished from the ceramic repertoire well before 600 BC. The coarse impasto storage jars, however, survived much longer and continued to serve the same purposes for many years (e.g. storage of cereals; interment of babies).

${ }^{154}$ In the Salento peninsula these same jars (but now wheelmade) were still made in the late 4th century BC (Yntema 2001, 323-324). 

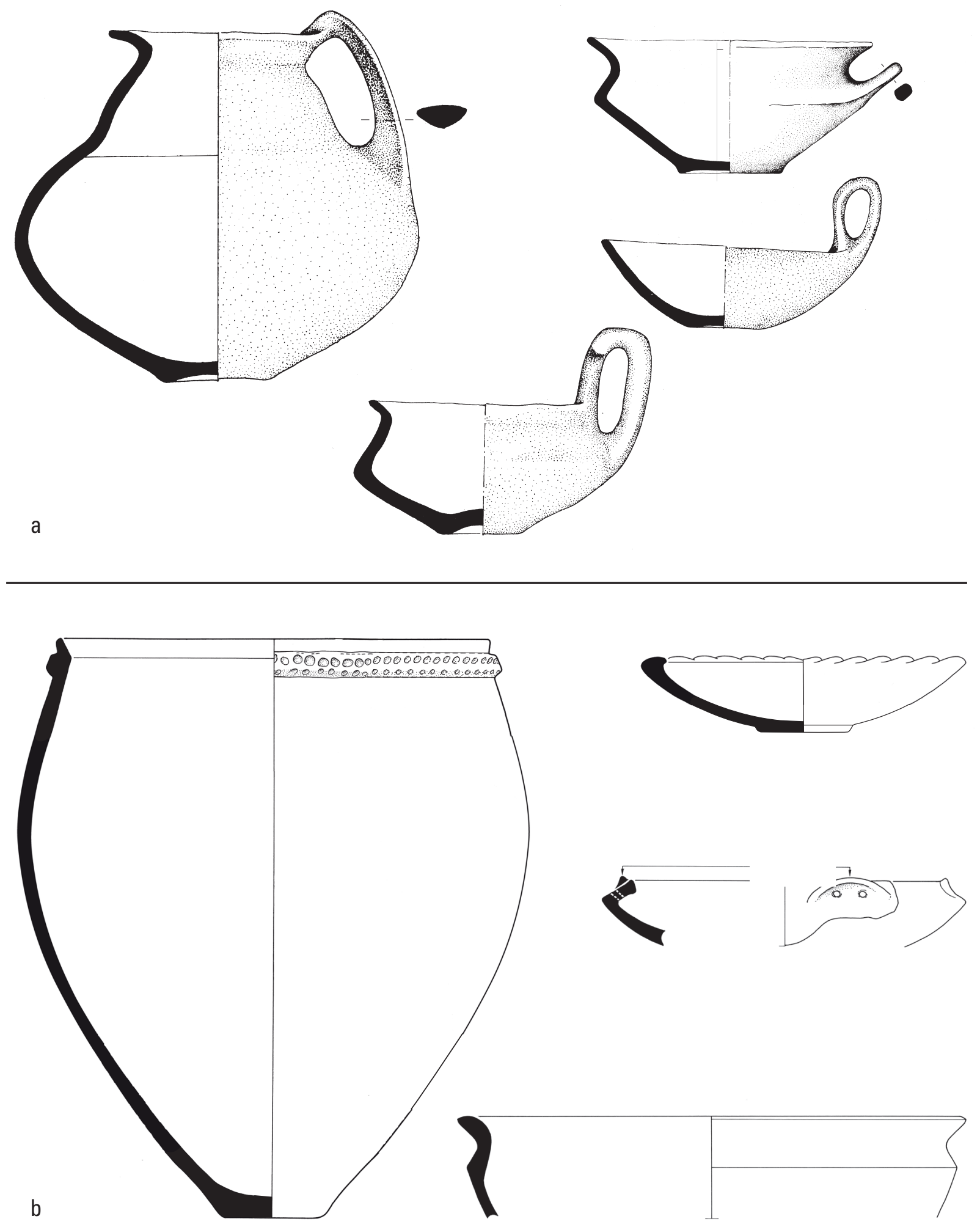

Fig. 4.25. Impasto wares of southeast Italy. (A) Selection of forms of impasto from the necropolis of L'Incoronata (9th-8th century BC); (B) Storage jars of coarse impasto and bowls of burnished impasto from the settlement of Valesio (Brindisi), first half of the 7th century BC. 


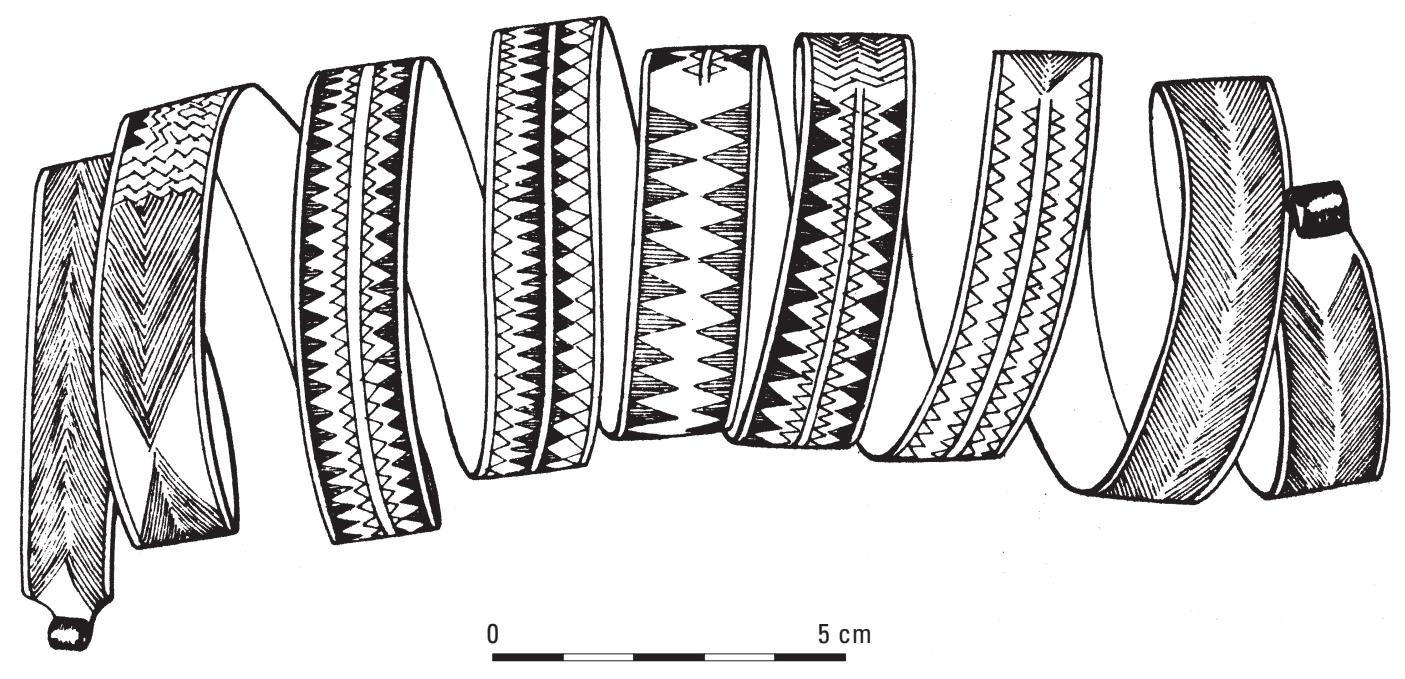

Fig. 4.26. Southeast Italy: metalwork of the Iron Age: bracelet from Matera area, 8th century BC; adapted from Lo Porto 1969.

On the strength of the complexity of the production process, matt-painted wares are likely to have been made by specialist potters. This does not necessarily mean that making pots was their only occupation. Ethnographic sources indicate that pottery production could well be a seasonal activity that takes mainly place in the summer months (Mater 2005). The group for which the pots were made was mostly small. Usually each settlement of southeast Italy had at least one potter who worked in most cases for a local clientele. ${ }^{155}$ The location of the production unit in relation to other features is telling. At Oria (Salento) the kiln site was very close to a substantial hut cluster of the settlement, whilst at Canosa (Ofanto district) the kiln site was in the same restricted area as a cluster of elite graves and traces of a 7th- and 6th-century habitation area. The Iron Age potters, therefore, were definitely part of the family group and part of the clan to which the family belonged. The potters who shaped and decorated the fine Canosan ceramics that reached elites in distant areas such as the northern Adriatic and Slovenia, may have been among the retinue of the great chieftains of Canosa who controlled the exchanges between Adriatic and south-Italian trade networks and who were buried in close proximity to their dwellings and their kilns.

Blacksmiths may have held a comparable social position in Iron Age southeast Italy. Their workshops have not been found. They produced a wide variety of articles of which only those survive that were deposited in the graves. They produced magnificent belts, swords (fig. 4.16), bracelets (fig. 4.26), a variety of fibulae and a host of other objects. The Daunian stelai ${ }^{156}$ and the graves of Basilicata ${ }^{157}$ give testimony of the great wealth of metal ornaments worn by Iron Age persons of substance in southeast Italy. The phenomenon that metal objects were more and more restricted to elite burials in the course

155 The exceptions to this general rule are the potters from the Tavoliere whose vessels reached the plain around Naples, the potters from Canosa-Toppicelli whose pots played a role in south-Italian and Adriatic exchange circuits (Yntema 1979) and the potters of the 8th century Tenda wares of western Basilicata (see La Genière
1968, Kilian 1970, Ruby 1988; Fabricotti / Martella 2001). At Canosa two workshops producing mattpainted wares may well have coexisted (see Yntema 1995, 71)

156 Nava 1981.

157 Bianco / Tagliente 1985; Chiartano 1977, 1994, 1996. 


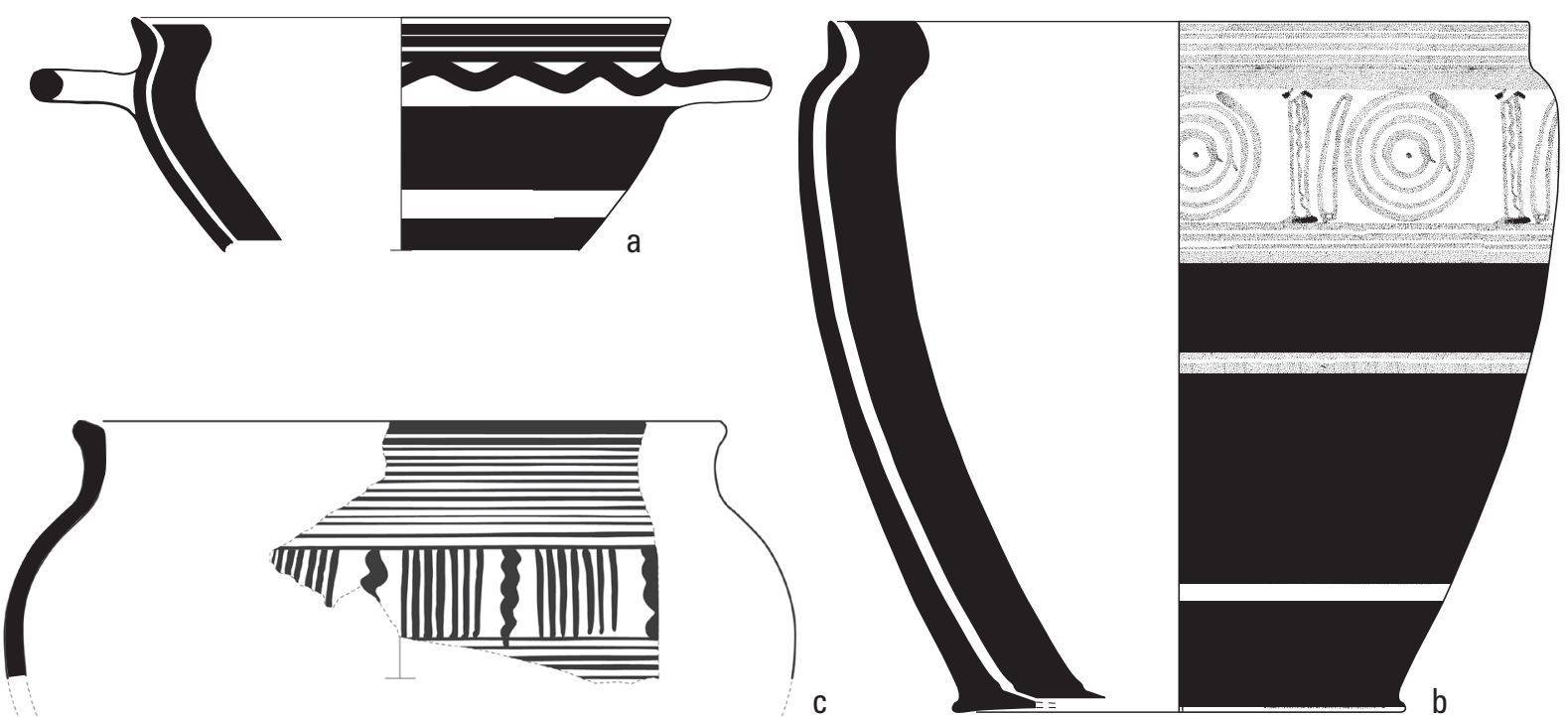

Fig. 4.27. Locally made Greek style ceramics from Metaponto-Andrisani (a-b; see De Siena 1985, Yntema 2000) and from L'Amastuola (c).

of the 7th century BC could well be a sign of an increasingly close link between the local elite and the local smith: the latter produced articles that were the prerogative of the former and that could also play a role in intra- and interregional elite exchange.

As we have seen above, one of the new features of the Iron Age was the drastic intensification of contacts with regions outside southeast Italy. On the Gulf of Taranto these resulted even in the settling of relatively small groups of Greeks who were traders, mercenaries and craftsmen. The first migrants arrived around $700 \mathrm{BC}$, but before the middle of the 7th century several small Greek communities had come into being by a steady trickle of Greek immigrants. These not only transported pots from the area of their roots to their new homes, they also brought their potter's craft to Italy.

The evidence for the production of Greek style pottery in southeast Italy is relatively abundant. The 'hard' evidence consists of a number of clay analyses and some wasters, but the substantial quantities of ceramics that have clays and decorations that are similar or identical to those that constitute the hard evidence are rather numerous. These suggest that around 650/640 BC the sites of Siris, L'Incoronata and Metaponto-Andrisani each had a workshop producing Greek-style pottery in basically Greek techniques. These ceramics were made on the quick potter's wheel, were decorated with a ferrous slip and fired at high temperatures. The motifs, moreover, belonged to the Greek subgeometric and orientalizing repertoires (fig. 4.27). In addition to painted wares, plain and relief decorated wares were made in these Greek pottery workshops of southeast Italy. A spectacular and well-preserved specimen of the latter class is the magnificent $0.78 \mathrm{~m}$ tall-footed basin (perirrhanterion) found (and presumably made) at L'Incoronata displaying battle scenes and typically Greek myths (fig. 4.28). ${ }^{158}$

Initially the impact of these south-Italian Greek wares on the traditional ceramic production of southeast Italy was limited. As we have seen above, the ceramics of the Basilicata districts on the Gulf of Taranto display a tendency towards increasingly linear decoration from the late 7th century onward

158 On these workshops producing Greek style ceramics in southeast Italy, see, for instance, Greci sul Basento, 144-168; Ciafaloni 1985; Lambrugo 2003 (all about L'Incoronata); De Siena 1986 (on MetapontoAndrisani). This relief decorated perirrhanterion was published by Orlandini (1980). 


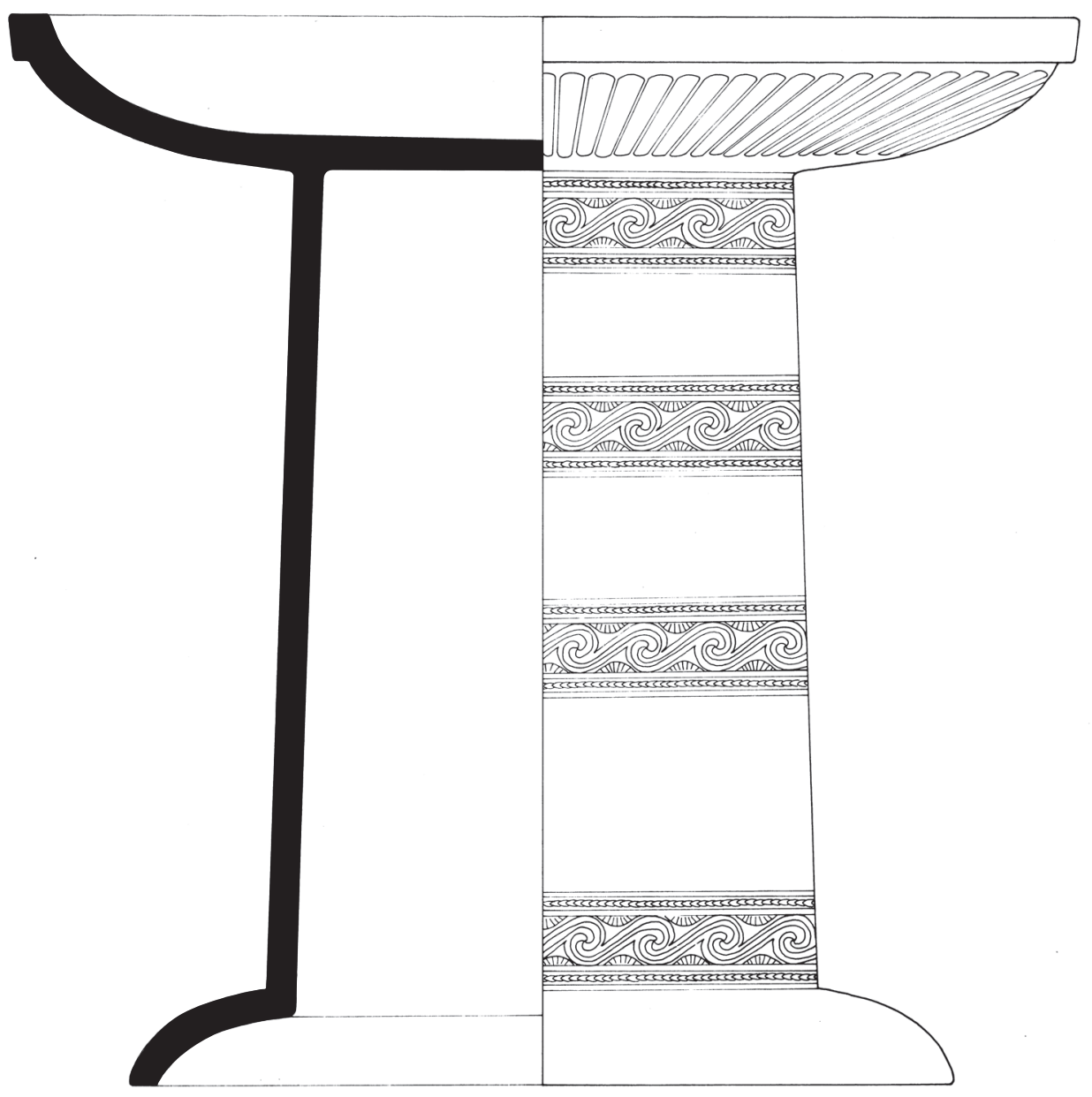

Fig. 4.28. Relief decorated perirrhanterion from L'Incoronata (final quarter late 7th century BC); adapted from Orlandini 1980.

(see fig. $4.23 \mathrm{~g}-\mathrm{i}$ ). In western Basilicata hybrids were made that combined Greek shapes with native matt-painted decoration (fig. 4.23h-i). It was, however, not before the 2nd quarter of the 6th century BC that Greek forms and techniques began to replace the traditional matt-painted ceramics on a large scale in larger parts of the region under discussion. These innovations will be discussed in the following chapter (section 5.5).

\section{$4 \cdot 7$ S U M M A R Y}

The Iron Age in southeast Italy displays features that have close parallels in the later phases of the Bronze Age. In both periods internal dynamics went hand in hand with external stimuli. Both factors cooperated in both periods in creating a different, more complex southeast Italy with natural, economic and socio-political landscapes that differed substantially from those preceding them. But while towards the close of the Bronze Age complexity decreased substantially, the end of the Iron Age is marked by drastic innovations. Among these were unprecedented population densities, an unprecedented intensity of the exploitation of the soils, unprecedented wealth for some and unprecedented prosperity for many. The story of the Iron Age is in fact a narrative about the first phase of a process of sometimes rapidly increasing complexity that would culminate in the subsequent Archaic-Classical, Hellenistic and Roman periods. 
As we have seen, the Iron Age of southeast Italy is characterized by considerable ferment. Many people were on the move in search of new farmland, a profitable exchange or ever lasting fame. Long distance contacts, exchange and migration suddenly gained momentum in the 8th century BC. Most of these 'travellers' just moved within the region under discussion. Small family groups decided to leave their settlements and undertook the laborious and undoubtedly risky task of creating new settlement areas and new fields for themselves in the midst of the woods of southeast Italy. Some of the people that were on the move were middlemen playing a role in exchanges between the various districts. Most of these were just visitors: they returned to their districts when the aim of their venture had been accomplished. Among these were Greek sailors and indigenous traders coming from Picenum or the Liburnian coast of present-day Istria and Dalmatia. Several foreigners, however, left their homes forever and came to stay in southeast Italy.

The largest group of migrants who started to live permanently in southeast Italy, was that of the Greeks. Initially relatively few individual Greeks settled in these new surroundings. That also happened in the Late Bronze Age. But by about the second quarter of the 7th century BC small Greek communities had come into being at the periphery or in the territory of originally non-Greek settlements. By about the third quarter of the same century the population of four coastal settlements began to increase very considerably (Sybaris, Siris, Metapontion, Taras). Each of these had a mixed population consisting of Greek immigrants and people with Italic roots. Their rapid growth in the later 7th century was probably due to their attraction to groups from the fermenting indigenous world of southeast Italy and to migrants coming from the equally fermenting Aegean areas. Their attractiveness lay in both the fertility of their soils and their geographic position as pivots (ports of trade) between two exchange systems.

It was in the late 7th century BC that a distinct bipolarity came into existence in southeast Italy. The four rapidly growing coastal settlements with their heavily mixed populations began to assume a new character. Their sudden expansion and rapidly increasing economic importance changed their role in the region dramatically. Whilst they were peripheral to indigenous groups and probably even dependent on indigenous groups in the earlier 7th century, they tended to evolve into more and more independent socio-political entities. Between the late 7th and the early 6th century BC they became new, impressive polities with a more or less urban centre. They unbalanced the traditional power structures and represented a major shift in the pre-existing power systems. By the middle of the 6th century BC southeast Italy harboured a series of indigenous tribes and four new city states. The latter proclaimed a new identity that suggested links with Greek-speaking areas surrounding the Aegean Sea.

The Greek-native bipolarity, however, should not be exaggerated. There were undoubtedly conflicts that marked the birth and sudden growth of the four Greek towns. In these conflicts people who probably began to see themselves as for instance Metapontines or Tarantines, fought against natives. But just as there was competition and fighting between native groups, there were conflicts and battles between the four Greek states. During the 7th century there was in fact no great divide in southeast Italy on the basis of strongly opposed Greek and Italic identities.

In the Iron Age, moreover, new settlements were not exclusively born on the coast. We have seen that many new territories were reclaimed and many new settlements arose in the inland areas of southeast Italy. The vast majority of these continued to be inhabited to well within the final centuries of the first millennium BC. The general lines of the pre-Roman habitation patterns of southeast Italy came into being in the course of the Iron Age. Later periods witnessed shifts and changes in the settlement hierarchy, but the basics of the habitation patterns as laid down in the Iron Age, remained untouched till well after the Roman conquest of southeast Italy.

In the Iron Age southeast Italy became a complex world. Since inland areas were reclaimed for human occupation on a large scale, population densities were much higher than in any preceding period. 


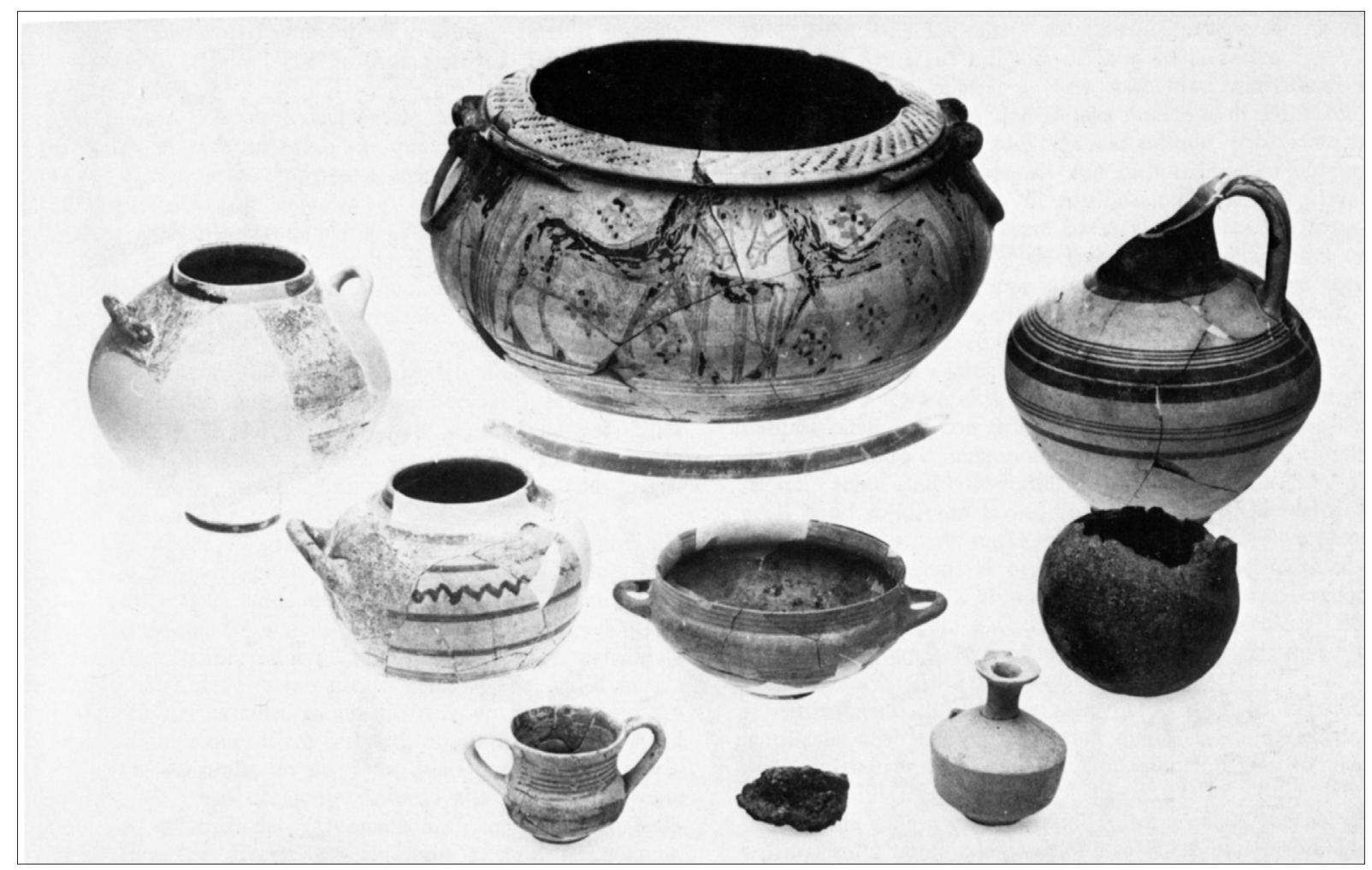

Fig. 4.29. Siris (western Basilicata). Elite burial of the late 7th century BC (Bianco / Tagliente 1985, 61).

Settlements, moreover, could have an unprecedented number of inhabitants. The dispersed Salento settlement of Oria is estimated to have had some 500 inhabitants in c. 700 BC. Lower population figures have been proposed for early Iron Age Sala Consilina in the uplands of southeast Italy, but this estimate is based on the assumption that each individual was formally buried. ${ }^{159} \mathrm{New}$, more concentrated settlements on the coast such as Metapontion may well have surpassed the population figure of early 7th-century Oria considerably around $600 \mathrm{BC}$. It was towards the end of the Iron Age that the first more or less urban centres of southeast Italy came into being. ${ }^{160}$

Many more elements suggest a considerable increase in complexity during the Iron Age. The large scale landscape infill is also among these. It required drastic initiatives and resulted in a considerable competition for soil. At the same time the increasingly sedentary character of human occupation was an agent in a process of regionalization and in the creation of more stable socio-political units with clearly defined territories. The intense, large scale exchanges over long distances complicated matters still further. They required planning and investment and involved risky but profitable ventures.

These new, rather drastic developments practically asked for new and powerful leadership taking initiatives. They also required an increased level of organization. It is, therefore, not surprising to witness the rise of distinctly local elites and local leaders in the later 8th century BC. Some of these may well have been of more than purely local importance in the later 7th century BC (e.g. the great

159 Yntema 1993a, 158; Kilian 1970, 293-294.

160 The term 'town' or 'urban centre' as used here, can be defined as: a settlement with a substantial population that has a central form of government, lives according to agreed (often written) rules and believes itself to be a community with a shared identity and a shared past; the community idea is often expressed in central elements in the local religion (communal cult building, communal cults) and manifested in communal enterprises such as public buildings (defences, urban sanctuaries, council buildings). 
chieftains of Canosa). The emerging elites of the entirely new polities that linked themselves more and more with the Greek world (i.e. the poleis), were persons of comparable status and comparable importance (fig. 4.29). Intermarriage between leading families of the emerging 'Greek' poleis and the elites of the patently non-Greek groups should certainly not be excluded. ${ }^{161}$ Such close, personal bonds between the elites of different groups could for instance be useful in forging alliances and summoning support in case of conflict. Moreover, the settlements in which the more-than-local leaders and chieftains of the late Iron Age (later 7th century BC) lived must have ranked above other settlements of the same district. Therefore, these are likely to have made up the upper echelon in the emerging site hierarchies of the various districts of southeast Italy. In this field too, an increased complexity can be observed.

Dynamics suggesting increased complexity are less evident in craft. Whilst many changes can be observed in the repertories of forms and ornaments of the ceramics (e.g. matt-painted wares), the production process and the organization of pottery production underwent no significant changes in large parts of southeast Italy. The same observation holds good for the production of metal objects and the construction of dwellings. All these objects continued to be made with the same traditional methods that were not different from those found during the final phases of the Bronze Age. Innovation in this field came late and came from abroad. The introduction of new techniques (e.g. wheelmade pottery, houses of stone and mudbrick) can be dated to about 660/640 BC. This phenomenon, moreover, was initially limited to a handful of coastal settlements. Four of these became Greek poleis during the final phase of the Iron Age. ${ }^{162}$ It was only in the course of the Archaic period (some 75 tot 100 years later) that these innovations spread over larger parts of southeast Italy (see chapter 5).

In the Iron Age the horizons of many people living in southeast Italy widened considerably. Whilst about $900 \mathrm{BC}$ their experiences with foreigners, distant countries, new landscapes and unusual ideas were minimal or absent, people living in c. $600 \mathrm{BC}$ had been confronted with entirely new worlds. Autochthonous Italians had left their coastal homes and penetrated the inlands of southeast Italy, carving new settlement areas and new fields out of formerly natural environments. Iron Age Apulians crossed the Adriatic and encountered the Iapodians and Illyrians who spoke languages that resembled their own Messapic tongue and lived in Istria, Dalmatia and Albania. These trans-Adriatic groups were also on the move and frequented settlements on the Adriatic shores of Italy. Greeks, moreover, left their homes in the Aegean and ventured towards the west in search of booty, kleos, trading commodities or farmland. These too, entered new environments and sometimes settled there. Various types of Greeks, Italians originating from southeast Italy, Campania, and the Marche/Abruzzo districts, and Adriatic groups in present-day Dalmatia and Albania met each other, robbed each other, exchanged goods in more friendly ways and made guest-friendships. They were confronted with each other's products, technologies, customs, ideas and perceptions. Since Greeks started to live in southeast Italy in substantial numbers and even carved new Greek polities out of the existing political landscape, the impact of the contacts between Greeks and Italians was great. Two large and varied groups with very different cultural features came into almost daily contact with each other. It resulted in culture contact and culture change, in intermarriage and conflicts, in people stressing traditional identities or proclaiming new identities and in persons able to live and work in two or more different cultural systems.

In this intense confrontation between cultural systems, individuals and groups made their choices. Sometimes these choices were deliberate and conscious, sometimes they were almost forced upon them as a result of changes. The Greek mercenary captain from western Asia Minor who came to Siris with

161 Cf. Van Compernolle 1983.

162 Houses were doubtlessly present in the four poleis in statu nascendi. They have also been unearthed at two sites that did not develop into a Greek polis: L'Incoronata (abandoned c. 600 BC) and L'Amastuola (Maruggi 1996; Burgers / Crielaard 2007 and 2011). 
his eight hoplites, was hired by the indigenous warrior chief of the inland settlement of Alianello and ended up marrying his daughter and being a venerated member of the local society of Alianello. His offspring became Oinotrians or Chaones or whatever label the inhabitants of 7th-century Alianello chose for themselves. The bastard son of a chieftain of Oria had to leave his indigenous settlement with his band of followers after a miscarried bid to attain power and - neglecting the possibility of founding an entirely new village - went to live in the increasingly Greek settlement on the lagoon of Taras. He and his offspring became Tarantines. The offspring of a Greek couple that had migrated to Siris and that was traditionally cremated and interred in one of Siris's necropoleis with one or two pots only, opted for inhumation in cist graves and was buried with a host of ceramics as was customarily done by the indigenous populations of southeast Italy. Both the inhabitants and their material culture hybridized.

In the Iron Age entirely new societies were born in southeast Italy. In the 8th century BC the region emerged from the somewhat isolated position it had held during the close of the Bronze Age and the early years of the Iron Age. Southeast Italy made links with networks of contact and exchange in which both crafted artefacts (objects) and mental artefacts (concepts) circulated widely. As a result of this all kinds of people in various parts of southeast Italy picked up new ideas on quite a number of topics. Moreover, the networks in which southeast Italy began to participate spanned increasingly large parts of the Mediterranean. In the long run the Greek diaspora was the most influential of these. But it was certainly not the only one. 
